\title{
Taxonomic revision and insights into the speciation mode of the spider Dysdera erythrina species-complex (Araneae : Dysderidae): sibling species with sympatric distributions
}

\author{
Milan Řezáč ${ }^{\mathrm{A}, \mathrm{G}}$, Miquel A. Arnedo ${ }^{\mathrm{B}}$, Vera Opatova ${ }^{\mathrm{B}, \mathrm{C}, \mathrm{D}}$, Jana Musilováa ${ }^{\mathrm{A}, \mathrm{E}}$, \\ Veronika RezáčováF and Jiří Král ${ }^{\mathrm{D}}$ \\ ABiodiversity Lab, Crop Research Institute, Drnovská 507, CZ-161 06 Prague 6-Ruzyně, Czechia. \\ ${ }^{B}$ Department of Animal Biology \& Biodiversity Research Institute, Universitat de Barcelona, Av. \\ Diagonal 643, 08028 Barcelona, Spain. \\ ${ }^{C}$ Department of Zoology, Faculty of Science, Charles University in Prague, Viničná 7, CZ-128 44 Prague 2, Czechia. \\ Department of Biological Sciences and Auburn University Museum of Natural History, Auburn University, \\ Auburn, AL 36849, USA. \\ ELaboratory of Arachnid Cytogenetics, Department of Genetics and Microbiology, Faculty of Science, \\ Charles University in Prague, Viničná 5, CZ-128 44 Prague 2, Czechia. \\ F Laboratory of Fungal Biology, Institute of Microbiology, Academy of Sciences of the Czech Republic, \\ CZ-142 20 Prague, Czechia. \\ GCorresponding author. Email: rezac@vurv.cz
}

\begin{abstract}
The genus Dysdera Latreille, 1804, a species-rich group of spiders that includes specialised predators of woodlice, contains several complexes of morphologically similar sibling species. Here we investigate species limits in the D. erythrina (Walckenaer, 1802) complex by integrating phenotypic, cytogenetic and molecular data, and use this information to gain further knowledge on its origin and evolution. We describe 16 new species and redescribe four poorly known species belonging to this clade. The distribution of most of the species in the complex is limited to southern France and the north-eastern Iberian Peninsula. The species studied do not show any obvious differences in habitat preference, and some of them even occur sympatrically at certain sites. They probably feed on the same type of prey as they readily capture woodlice. On the other hand, they differ in body size, mouthparts shape, sculpturing of carapace, morphology of the copulatory organs, karyotype and DNA sequences. Experimental interspecific mating showed a partial precopulatory behavioural barrier between $D$. erythrina and $D$. cechica, sp. nov. Our data suggest that karyotype evolution of the complex included chromosome fusions and fissions as well as translocations (between autosomes as well as autosomes and sex chromosomes). We hypothesise that chromosome rearrangements generating reproductive incompatibility played a primary role in speciation within Dysdera complexes. Dysdera spiders are poor dispersers, and their original distribution areas (forested areas in the Mediterranean) were repeatedly fragmented during Quarternary climatic oscillations, facilitating integration of chromosome rearrangements into karyotypes by genetic drift. Sympatric occurrence of closely related species may have been promoted by prey segregation as suggested by differentiation in body size in co-occurring species. The following new species are described: $D$. catalonica, sp. nov., D. cechica, D. dolanskyi, sp. nov., D. fabrorum, sp. nov., D. garrafensis, sp. nov., D. graia, sp. nov., D. kropfi, sp. nov., D. minairo, sp. nov., D. portsensis, sp. nov., D. pradesensis, sp. nov., D. pyrenaica, sp. nov., D. quindecima, sp. nov., D. septima, sp. nov., D. stahlavskyi, sp. nov., D. tredecima, sp. nov. and D. undecima, sp. nov.
\end{abstract}

Additional keywords: holokinetic, interspecific recognition, karyotype evolution, Mediterranean, new species, precopulatory barrier, prey segregation, sex chromosome, woodlice.

Received 3 March 2016, accepted 3 May 2017, published online dd mmm yyyy

\section{Introduction}

Species of the genus Dysdera Latreille, 1804 are ground-dwelling spiders mostly found in xerothermic forests. They are active nocturnal predators that spend daylight sheltered in silk nests under stones and dead logs (Cooke 1965a). Dysdera is a western Palearctic lineage with most species native to a limited region of 
the Mediterranean basin. The only exception is the anthropogenic D. crocata C. L. Koch, 1838, which has been accidentally introduced to almost all continents (Nedvěd et al. 2011). Several remarkable features make the genus Dysdera an 5 interesting group for studying speciation. First, Dysdera is by far the richest genus of the family Dysderidae and one of the richest spider genera in the Mediterranean. To date, more than 250 species have been described (World Spider Catalog 2016). Moreover, the number of species is probably much higher, as 10 suggested by the increasing number of new species described in the past few decades (see World Spider Catalog 2016).

Second, Dysdera exhibits a considerable karyotype diversity; male chromosome numbers of these spiders range from 9 to 40 (Řezáč et al. 2007). This remarkable variability is probably

15 related to the holokinetic stucture of dysderid chromosomes, which facilitates regular segregation of fragments as well as fused chromosomes during division, and thus increases probability of fixation of such mutations (Jacobs 2004). Fixation of fragments leads to an increase, whereas fixation of

20 fused chromosomes leads to a decrease of the chromosome number. Chromosome speciation is a typical example of speciation by genetic drift (Qumsiyeh 1994). Hybridisation of two species differing by chromosome rearrangements produces individuals that usually exhibit reduced fitness and/or inviability

25 of their offspring due to irregularities in meiotic division during formation of gametes (Macgregor 1993). Therefore, natural selection maintains karyotypes conserved within species (Rieseberg 2001). Because of selective constraints, the karyotype is among the most conserved features of a species, and

30 has been used as a relevant character in spider taxonomy (e.g. Král et al. 2006; Řezáč et al. 2006; Araújo et al. 2008). Differences in karyotypes are especially useful in the detection of cryptic species (Dobigny et al. 2005).

Third, Dysdera includes complexes of sibling species only 35 distinguished by subtle morphological differences. Also, the copulatory organs, which are otherwise highly divergent among spider species (Eberhard 1985), are very similar among the species of these complexes. Fourth, closely related Dysdera species show often overlapping distributions, and more than one

40 species frequently co-occur in a single locality (e.g. Arnedo and Ribera 1999). Sister species occurring in sympatry often differ in the morphology of the mouthparts and/or body size (e.g. Deeleman-Reinhold and Deeleman 1988; Arnedo et al. 2007). Finally, some Dysdera spiders are prey specialists (Řezáč et al.

$452008 b$ ), and they are the only known predators specialised to hunt woodlice outside the tropics (cf. Sutton 1980).

For a long time, information about prey preferences was only available for the two most widespread Dysdera species, D. erythrina (Walckenaer, 1802) and D. crocata. These species

50 have been repeatedly observed to capture woodlice in nature (e.g. Bristowe 1958; Hopkin and Martin 1985; Raupach 2005). Feeding on woodlice has been confirmed by a survey of remnants in silk retreats of these spiders (Cooke 1965a), and by detecting woodlice antigens in their digestive tract (Sunderland and Sutton

55 1980). However, the same species were observed to catch almost all slow-moving, relatively small arthropods in the laboratory (Cooke 1965a, 1965b, 1965c). Moreover, D. crocata did not prefer woodlice to other arthropods in laboratory experiments (Pollard et al. 1995). All these results cast doubt on the consideration of Dysdera as a prey specialist. However, further experiments showed that even the species that do not prefer woodlice in prey-preference experiments are metabolically adapted woodlice specialists (Řezáč and Pekár 2007; Pekár et al. 2016). Nevertheless, Dysdera species differ in their degree of diet specialisation: some seem to be generalist predators while others are obligatory woodlice specialists that exhibit morphological adaptations in their mouthparts and perform specific capture tactics allowing them to grasp and

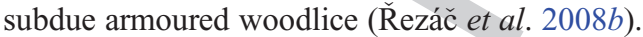

Although there is available information on the morphology and distribution (e.g. Deeleman-Reinhold and Deeleman 1988), the karyotype (Řezáč et al. 2008a) and the genetic diversity (e.g. Arnedo et al. 2001) of several Dysdera species, there has been little effort to integrate all this information for a better understanding of the evolution of Dysdera species complexes. This approach has been applied only recently to analyse the D. ninnii-complex (̌́ezáć et al. 2014). To obtain a deeper insight into the evolution of Dysdera complexes, we present here an integrated analysis of the $D$. erythrina-complex. Like the $D$. ninnii-complex, the $D$. erythrina-complex includes phenotypically similar, presumably recently diverged species. We hypothesise that these young species mainly differ in features that played an important role in their speciation. Old taxa often lack clear signatures of the speciation process, which is usually obscured by subsequent evolutionary history (Jiggins and Mallet 2000). Notably, the $D$. ninnii and $D$. erythrina complexes differ by (1) species distribution and (2) species-specific characters, which could reflect specific features of their evolutionary history. Our results allow us to compare the evolution of both complexes, which further elucidates speciation in the genus Dysdera.

The heterogeneity of the taxon $D$. erythrina was recognised by Simon (1882), who distinguished three very similar species to D. erythrina, namely, D. fervida Simon, 1882, D. lantosquensis Simon, 1882 and D. provincialis Simon, 1882. However, he subsequently considered these taxa to be 'local forms' of D. erythrina (Simon 1914). They were also neglected in the modern revision of the genus Dysdera by Deeleman-Reinhold and Deeleman (1988), but more recently, D. lantosquensis was raised to species status by Řezáč et al. (2007).

In the present study, we conducted an integrative taxonomic revision of the erythrina species-complex. Detailed information about the morphological differences, habitat preferences, phenology and distribution of members of the erythrinacomplex has been compiled from thorough sampling of 45 specimens obtained during several excursions, provided by colleagues or stored at natural history institutions. Additionally, karyotypes are described, prey preference analysed, interspecific mating experiments performed and DNA barcode information gathered. The integration of all these data confirms Simon's species, uncovers 16 new species, and provides novel insights into the general speciation mechanisms responsible for the origin of Dysdera species complexes.

\section{Materials and methods}

The candidate species were first delimited using morphology. Karyological analyses further revealed a diverse number of distinct karyotypes that mostly corresponded to the 
morphologically defined species. DNA barcodes were then used to corroborate the former species hypotheses. Some closely related species differ by considerable karyotype differences, which certainly represent interspecific barriers. We considered 5 these differences to be sufficient for species delimitation even in cases when such delimitation was not further supported by morphological or molecular markers.

\section{Morphology and function of copulatory organs}

Dysdera spiders possess a specific morphology of the copulatory used by Arnedo et al. (2000, 2009). Further, several features were unique to the copulatory organs of the D. erythrina-complex; we used new names for them to simplify descriptions (see the general morphological description of the complex at the beginning of the 'Results' and in Fig. 1). Here, we provide only a general description of Dysdera copulatory organs. The Dysdera male copulatory organ, the bulb (Fig. 1A), is composed of two parts the proximal tegulum and the distal division. The tegulum is sclerotised, mainly smooth; its distal margin bears a heavily sclerotised posterior apophysis. The distal division is composed of a whitish, membranous, distal haematodocha and darkcoloured sclerites.

$(A)$

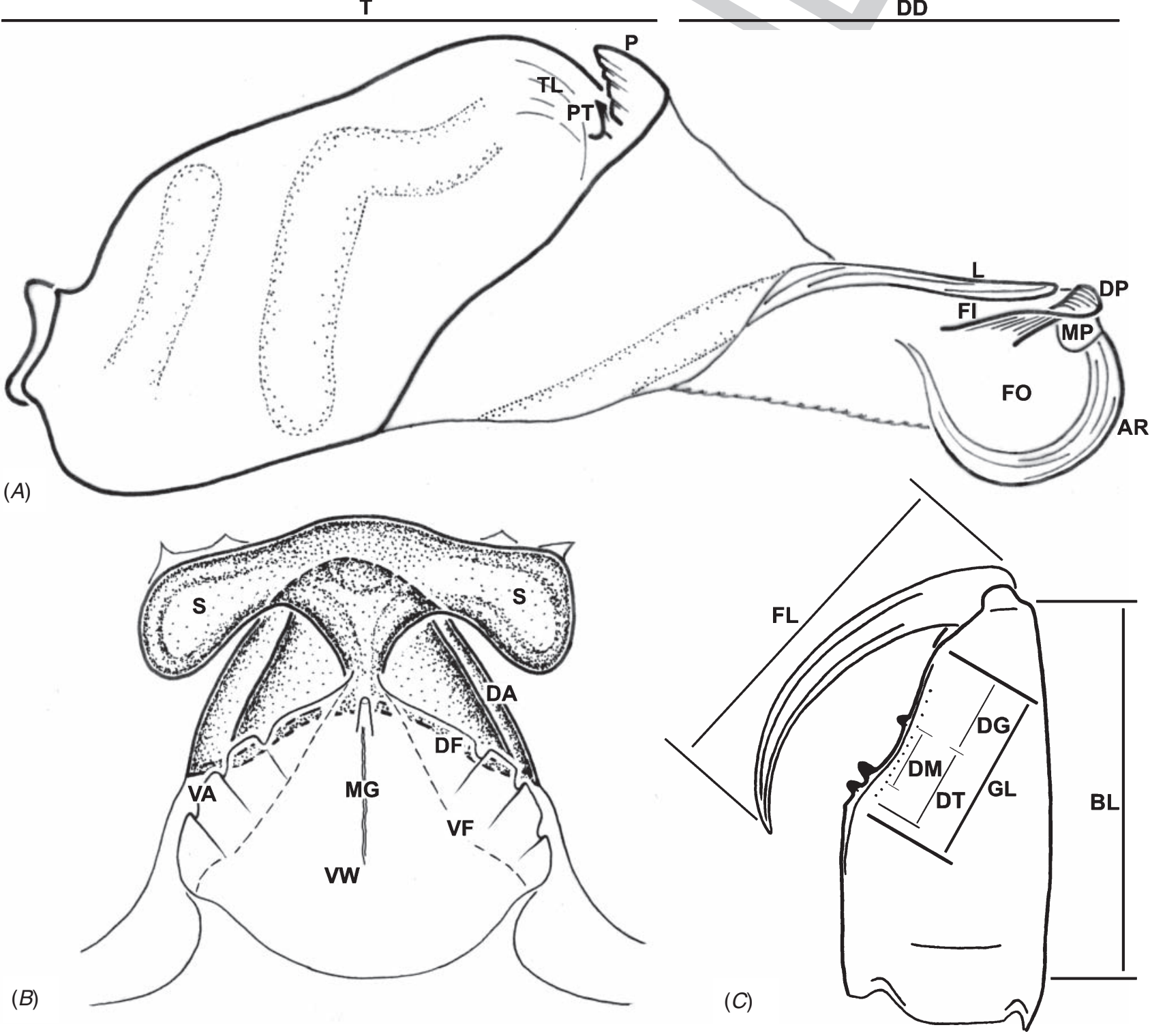

Fig. 1. Dysdera erythrina (Walckenaer, 1802), morphological characteristics: $(A)$ left bulb, retrolateral view; AR, arch-like ridge; DD, distal division; DP, distal projection; FI, fissure; FO, fosette; TL, lump; L, lateral sheet; MP, membranous patch; P, posterior apophysis; PT, tooth of posterior apophysis; T, tegulum; $(B)$ anterior part of vulva, spermatheca and copulatory bursa, ventral view; DA, dorsal arch; DF, dorsal fold; MG, medial groove; S, spermatheca; VA, ventral arch; VF, ventral fold; VW, ventral wall; $(C)$ chelicera, dorsal view; BL, basal segment (paturon) length; DG, distance of distal tooth from distal end of groove; DM, distance between distal and middle tooth; DT, distance between distal and proximal tooth; FL, fang length; GL, length of groove. 
Like other haplogyne spiders, Dysdera females lack an external complex of genitalic sclerotised structures (epigyna). The internal genitalic structures (vulva) include several diverticles with different levels of sclerotisation that may be 5 involved in postcopulatory female choice (Uhl 2000). To investigate the morphology of these structures under a light microscope, the vulva was dissected and brightened using concentrated glycerol. The vulva is located in the anterior ventral side of the opisthosoma and opens to the exterior

10 through the epigastric furrow. The vulva is composed of two main diverticles: the anterior diverticle that includes the spermatheca and the copulatory bursa (Fig. 1B) and the posterior diverticle, a membranous pocket that constitutes a putative synapomorphy of the families of the superfamily

15 Dysderoidea sensu Forster and Platnick (1985). The copulatory bursa is bound dorsally by a sclerotised crescent called the dorsal arch (DA), and ventrally by a membrane called the ventral wall (VW). The dorsal posterior margin of the DA is folded towards the uterus (dorsal fold, DF), whereas

20 the VW is directly connected to the genital opening. In a relaxed state, the lateral walls of the copulatory bursa are flexuous like an accordion, where sclerotised and membranous parts alternate. Ventrally from the DA, there is another sclerotised arch (ventral arch, VA) separated from the DA by a fold (ventral fold, VF). The

25 DA and the VA may exhibit different, species-specific levels of sclerotisation. In some Dysdera species not treated in this study, these two arches may fuse and the sclerotised VF becomes a flap-like internal rim (see Arnedo et al. 2000: figs 11-16). The VW may include a second lateral fold that ventrally defines an

30 additional ventral diverticle. Moreover, some species exhibit additional transverse folds on the ventral wall (Fig. 1B). The inner side of the ventral wall is longitudinally divided by a groove (medial groove), which anteriorly continues as a channel leading to the spermatheca. The spermatheca is a heavily sclerotised 35 transversal hollow rod with muscles attached anteriorly and glands on its dorsal side (for the function of these structures, see Uhl (2000) and Burger (2011)). The posterior diverticle hangs on the sclerotised arched transversal bar with muscle anchors. In its middle part, the bar has a wide lobe that locks to the dorsal

40 fold of the anterior part of the vulva, functioning through the action of muscles as a bursal valve. The posterior part of the vulva is not used in this study (absent in Fig. $1 B$ ) because we failed to find any informative characters for the members of the D. erythrina-complex.

45 For a better understanding of the function of particular structures of the copulatory organs, we froze five couples of $D$. erythrina by submerging them in liquid nitrogen during copulation. The vulva was then dissected with both bulbs retained inside it. The reciprocal position of the genitalic organs

50 was observed in glycerol with a dissecting microscope. The organs disconnected during manipulation before photodocumentation could take place; however, verbal description of the arrangement is sufficient for the purpose of this study.

\section{Measurements and views}

55 We took a range of measurements to facilitate recognition of particular species. We measured the length of the distal division and total length of the bulb (Fig. $1 A$ ) in retrolateral view. The bulb can rotate in the joint with the pedipalpal tarsus, thus changing its position in relation to the pedipalp. When describing the retrolateral view, we refer to the view when the posterior apophysis is pointing upwards and the fosette is facing the observer (Figs 1A, 5, 7). While observing the living, relaxed spider, this side is visible from the retrolateral view to the pedipalp. The side shown in Fig. 9 (opposite to the side equipped with the posterior apophysis) is facing the front when the pedipalp is stretched forward; here we will refer to this as the frontal view. Even a slight change of viewing angle can change an evaluation of the proportions. The bulb, when laid on a horizontal plane, has two stable positions; namely, the prolateral (i.e. opposite to retrolateral; Fig. 6) and hind view (i.e. opposite to frontal; Fig. 8). Thus, these views can be easily compared when the bulb is detached from the pedipalp.

The width of the carapace was taken at its widest point. The length of the gnathocoxa was measured from the tip to the base of the pedipalpal coxa. Measurements of the chelicerae are specified in Fig. $1 C$. The lateral measurement of the length of the basal cheliceral segment did not include the proximal part, which was hidden within the carapace. The width of this segment was measured in the middle of the lateral side.

\section{Scanning electron microscopy}

Specimens preserved in ethanol were used for scanning electron microscopy (SEM). The male prosomas and the male copulatory organs were isolated. The female genitalia were dissected, macerated in $5 \% \mathrm{KOH}$ until the soft tissues were dissolved, and washed in distilled water. Samples were then dried at room temperature, mounted on a stub, coated with gold and examined using SEM (JEOL 6380 LV).

\section{Molecular data analyses}

Molecular data were obtained for most species of the D. erythrina-complex (Table $\mathrm{S} 1$, available as supplementary material to this paper). The species D. valentina Ribera, 2004 was included as an outgroup following Arnedo et al. (2009). Protocols for specimen handling, DNA extraction, amplification and sequencing of the gene fragments followed those of MacíasHernández et al. (2008). In selected specimens, the DNA barcode fragment of the cytochrome $c$ oxidase I (COI) was amplified using the primer combination C1-J-1490 and C1-N-2191 (Folmer et al. 1994) or, alternatively, C1-J-1546 and C1-N-2194 (BidegarayBatista et al. 2007). Sequences were edited and handled using the computer program GENEIOUS v. 4.7 (Drummond et al. 2009). Additional outgroup sequences were obtained from GenBank (Table S1).

Sequences were clustered into groups using three different evolutionary criteria, namely, the general mixed Yule-coalescent (GMYC) model (Pons et al. 2006; Fujisawa and Barraclough 2013), the Poisson tree processes (PTP) model (Zhang et al. 2013) and the inferred independent haplotype networks, which have been shown to correspond roughly to nominal species (Hart and Sunday 2007). The GMYC uses a likelihood-based approach to fit coalescent (population) and speciation (Yules) models to an ultrametric sequence tree to identify a transition point below which branch lengths are better explained by species level processes. Unlike the GMYC approach, the PTP does not 
require an ultrametric tree as input and has been shown to outperform the GMYC when evolutionary distances between species are small (Zhang et al. 2013) and be less sensitive to the use of alternative phylogenetic methods (Tang et al. 2014).

For the GMYC, ultrametric trees were obtained using two different strategies. First, we inferred an ultrametric tree in a Bayesian framework, as implemented in the program BEAST v. 1.8.1 (Drummond et al. 2012), using a lognormal relaxed clock. The mean of a normally distributed prior for the ucld.mean was arbitrarily set to 1 , to obtain relative node heights. We adopted a conservative approach (i.e. to minimise overlumping) to GMYC clustering by setting the tree before to follow a constant population size as coalescent (Monaghan et al. 2009). The best partition scheme and the preferred model for each partition were 15 selected with the help of the software PartitionFinder (Lanfear et al. 2012) using the Bayesian Akaike infomation criterion. We conducted three independent runs of 10 million generations each. Convergence among runs and correct mixing of the chains was monitored with the program Tracer v. 1.6 (http://tree.bio.ed.ac.

$20 \mathrm{uk} /$ software/tracer/, accessed 5 June 2012). The burn-in was removed and the runs combined with the help of the BEAST accompanying programs LogCombiner and TreeAnnotator. Second, we inferred the best tree using a maximum likelihood (ML) approach. Searches were conducted with the stand-alone 25 version of the computer program RAxML v 7.2.8 (Stamatakis 2006). Individual models of nucleotide substitution (GTR $+\Gamma$ with 25 categories) were specified for the preferred partition scheme (see above). The best trees and non-parametric bootstrap clade support were jointly estimated using the extended majority-rule consensus (MRE)-based bootstrap stopping criterion (750 replicates). The best ML tree obtained was further transformed into ultrametric with the program PATHd8 (Britton et al. 2007), arbitrarily setting the root length to 1 . The R package SPLITS v. 1.0-19 was used to identify the GMYC clusters using the single 5 threshold method, after removing zero-length branches and forcing the tree to be fully dichotomous. PTP groupings were inferred using the stand-alone version of PTP (available at https://github.com/zhangjiajie/SpeciesCounting, accessed 10 May 2015) on the best ML tree. In all cases above, trees were constructed and manipulated with the assistance of the computer program FigTree v. 1.3.1 (http://tree.bio.ed.ac.uk/software/ figtree/, accessed 20 November 2012).

Finally, sequences were clustered based on haplotype subnetworks. Unique haplotypes were collapsed with the 45 help of the Templeton-Crandall-Sing (TCS) allele network construction method program (Clement et al. 2000), which was also used to build haplotype networks under statistical parsimony (connection limit $=11$ ).

Pairwise intra- and interspecific uncorrected distances were explored using the program TaxonDNA (Meier et al. 2006).

\section{Distribution, habitat preferences and phenology}

Data on distribution and habitat preference were obtained from the labels of specimens available in the revised collections and from surveys conducted by the authors (sites in the lists of 55 examined material where M. Řezác or M. Arnedo are stated as collectors, the complete list of the examined material is available as supplementary material to this paper). Vegetation of inspected sites in Czechia and Slovakia was characterised after Chytrý et al. (2001)

Phenological data were inferred from observations at the visited sites. Some Czech and Slovak sites of D. erythrina and D. cechica, sp. nov. were inspected repeatedly to ascertain the differences in population structure through the year. At least five individuals were checked for developmental stage during each inspection. Additional data were obtained from the collections by considering sampling dates and developmental stages.

\section{Prey preference}

We performed experiments to assess whether the studied species were oniscophagous (readily feeding on woodlice) and, if so, which tactic they use to grasp woodlice. Preliminary experiments indicated that a two-week starving period is sufficient to make Dysdera spiders moderately hungry. Therefore, the specimens for experiments were kept without prey for this period (at $20^{\circ} \mathrm{C}$ and $90 \%$ relative air humidity). The woodlouse Porcellio scaber (Latreille, 1804) was used as prey, as it was the most abundant woodlice at some of the study sites. As a control prey, we chose the juvenile house cricket Acheta domesticus (Linnaeus, 1758), which is a frequent prey of many polyphagous spiders (Nentwig 1987). The size of both the woodlouse and the cricket roughly corresponded to the length of the spider's prosoma in all Dysdera species. We placed a woodlouse into a Petri dish (diameter $33 \mathrm{~mm}$ ) occupied by a spider. When the spider did not capture the woodlouse after $30 \mathrm{~min}$, we removed it and offered a cricket for another $30 \mathrm{~min}$. Refusal versus acceptance of the prey was recorded. Specimens that refused both animals were tested on consecutive days.

Grasping tactics were classified into three types according to Řezác et al. (2008b). 'Pincers' refers to the spider turning the prosoma sideways between the chelicera, enabling the insertion of one fang into the soft ventral side while the other fang grasps the hard dorsal side of the woodlouse. Using the 'fork' tactic, the spider tucks the chelicerae under a woodlouse and inserts its fangs into the soft ventral side. Using the 'key' tactic, the spider searches with one fang for an edge of a sclerite on the woodlouse's dorsal side and then slides the same fang under the sclerite. The specimens used in the prey preference experiments are listed in the Table S2. We used the program $\mathrm{R}$ to compare the frequencies of used tactics by the exact binomial test.

\section{Interspecific mating}

Interspecific mating experiments were conducted for the species D. erythrina and D. cechica. These species occur parapatrically in central Europe, so hybridisation may be a possibility. Ten adults of each sex of $D$. erythrina (Czechia: Prague-Ruzyně, $50.0839^{\circ} \mathrm{N}$, $14.3125^{\circ} \mathrm{E}$ ) and D. cechica (Czechia: Pardubice, $50.07972^{\circ} \mathrm{N}$, $15.81222^{\circ} \mathrm{E}$ ) were collected in April 2003. Twenty couples were tested in total. Five males and five females of one species were coupled with partners of the other species. As a control, five males and five females were coupled with conspecific partners. Each pair was placed in a Petri dish (diameter $33 \mathrm{~mm}$ ) for an hour and the resulting behaviour (mating or avoidance) was recorded.

\section{Cytogenetic analysis}

The studied material is summarised in Table S3. The most appropriate ontogenetic stage for cytogenetic analysis for all 
species was found to be the adult male when collected between the end of summer and the beginning of spring. At this stage, the testes contained dividing cells suitable for study, including spermatogonial mitoses as well as a range of meiotic stages

5 (Řezáč et al. 2007, 2014). Spermatogenesis in adult males was classified into three periods according to the proportion of mitotic and meiotic cells and some variation in the timing of these periods was observed in particular species (Table S3). Female mitotic plates were obtained from the ovaries and/or 10 intestine. In seven species, several populations were available for study. These species show homogeneity of karyotypes across different populations. The chromosome preparations were obtained following the method described in Rezáč et al. (2006). Preparations were observed under an Olympus BX 50

15 microscope and black-and-white images were recorded using a DP 71 CCD camera (Olympus). Plates were photographed using an oil immersion lens $(100 \times)$. In each species, the chromosomes of five or 10 plates of a selected specimen were evaluated with the single exception of $D$. portsensis, in which only three 20 suitable plates were available. Mitotic metaphases were used for analysis except for $D$. dolanskyi, sp. nov., whose preparations did not contain a sufficient number of mitotic plates; 10 plates of anaphase I were used instead (Table S4). The relative chromosome lengths (RCL) were calculated as a percentage of the total chromosome length of the haploid set, including the sex chromosome.

\section{Abbreviations}

Collections are abbreviated as follows: AMS, Australian Museum, Sydney, Australia; BMNH, British Museum of

30 Natural History, London, UK; CRBA, Centre de Recursos de Biodiversitat Animal, Universitat de Barcelona, Barcelona, Spain; EBH, Eastern Bohemian Museum, Pardubice, Czechia; FG, F. Gasparo personal collection, Trieste, Italy; HNHM, Magyar Természettudományi Múzeum, Budapest, Hungary;

35 JL, J. C. Ledoux personal collection, Solignac sur Loire, France; MNHN, Muséum national d'Histoire naturelle, Paris, France; MR, M. Řezáč personal collection, Prague, Czechia; NHRS, Naturhistoriska Riksmuseet, Stockholm, Sweden; NMB, Naturhistorisches Museum, Basel, Switzerland;

40 NMBB, Naturhistorisches Museum der Burgergemeinde, Bern, Switzerland; NMPC, Národní Muzeum, Prague, Czechia; NMW, Naturhistorisches Museum, Wien, Austria; ZMHB, Museum für Naturkunde, Humbold Universität, Berlin, Germany.

The abbreviations used for the various morphology features 45 are as follows: ALE, anterior lateral eyes; AR, arch-like ridge; DA, dorsal arch; DD, distal division; DF, dorsal fold; DP, distal projection; FI, fissure; FO, fosette; L, lateral sheet; MG, medial groove; MP, membranous patch; P, posterior apophysis; PLE, posterior lateral eyes; PME, posterior median eyes; PT, tooth

50 of posterior apophysis; S, spermathecal; T, tegulum; TL, lump; VA, ventral arch; VF, ventral fold; VW, ventral wall.

\section{Taxonomy}

\section{Genus Dysdera Latreille}

Type species: Aranea erythrina Walckenaer, 1802, by original designation.

\section{Dysdera erythrina species complex}

\section{Description}

Carapace. Length $=2.0-5.3 \mathrm{~mm}$ (sexes do not differ in size). Relative length (length/maximum width ratio) $=1.17-1.34$, Relative height (maximum height/length ratio $)=0.25-0.33$. The carapace behind the eyes can be more (Fig. $2 A$ ) or less (Fig. 2B) domed when viewed from the lateral side. The frontal and posterior lateral margins of carapace are rounded, whereas the lateral margins could be rounded (e.g. Fig. 3Q) or slightly angular (e.g. Fig. $3 E$ ). The carapace is typically two times longer than the width of cephalic area and the surface is either gently (e.g. Fig. 2D) or roughly wrinkled (e.g. Fig. $2 E$ ) and ferruginous (e.g. Fig. 3E); chestnut brown (e.g. Fig. 3C) or reddish brown (e.g. Fig. 3B), with dense dark spots which mainly occur in front of the fovea. The cephalic part, especially clypeus, is covered with setae.

Eyes. The ALE have a diameter of $0.13-0.23 \mathrm{~mm}$, the PLE $0.12-0.23 \mathrm{~mm}$ and PME $0.10-0.19 \mathrm{~mm}$. Located close to the PLE, the ALE are located a distance from the edge of the frontal border equivalent to their diameter, and are separated from one another by a distance approximately equal to two-thirds of an eye diameter. The PME are located very close to each other, less than 1/4 of PME diameter from PLE.

Sternum. Ferruginous to yellow, almost smooth to roughly wrinkled (especially on sides between coxae). Small pits with slender black setae. These hairs are usually only found on the sides of the sternum.

Labium. Trapezoid, longer than wide at base, notched at the tip.

Gnathocoxae. Relative gnathocoxa length (gnathocoxa length/carapace length ratio) $0.36-0.40$.

Chelicerae. Relative chelicera length (paturon + fang length/carapace length ratio) $0.77-0.95$. Relative paturon width (paturon width at the centre of the lateral side/carapace length ratio) $0.17-0.23$. Relative fang length (fang length/ chelicera length ratio) 0.44-0.49. Relative fang furrow length (length of fang furrow/length of paturon ratio) 0.54-0.76. Fang 'furrow' with three teeth in one row (unclear whether pro- or retrolateral, there is no real furrow between the teeth - general feature of the genus Dysdera) and lamina at base is shown in Fig. $1 C$. The medial tooth is usually the largest, and the position of the distal tooth (the distance between the distal tooth and the distal end of the fang furrow/length of fang furrow ratio) is $0.63-0.83$. The basal tooth is located close to the basal lamina and the position of the middle tooth (the distance between the distal and middle tooth/distance between the distal and proximal tooth ratio) is $\sim 0.43-0.70$. The anterior side of the paturon may be slightly concave (Fig. $2 A$ ) or straight (Fig. $2 B$ ). On the proximal (basal) part of the paturon the setae grow from dark bulbed bases (tubercules), whereas on the distal part of the paturon they grow from small pits. In some species, dark tubercles are only found at the base (e.g. Fig. 3C), whereas in others they can cover up to two-thirds of the cheliceral front (e.g. Fig. 3O).

Legs. Relative length of legs differs among the species (e.g. first femur length/carapace length ratio is $0.75-0.91$, detailed in Appendix 1). All segments have the same colouration (brown, ferruginous or yellow) although legs I and II are usually slightly darker. The tarsal claws at the end of the legas have 9 or 10 teeth. 

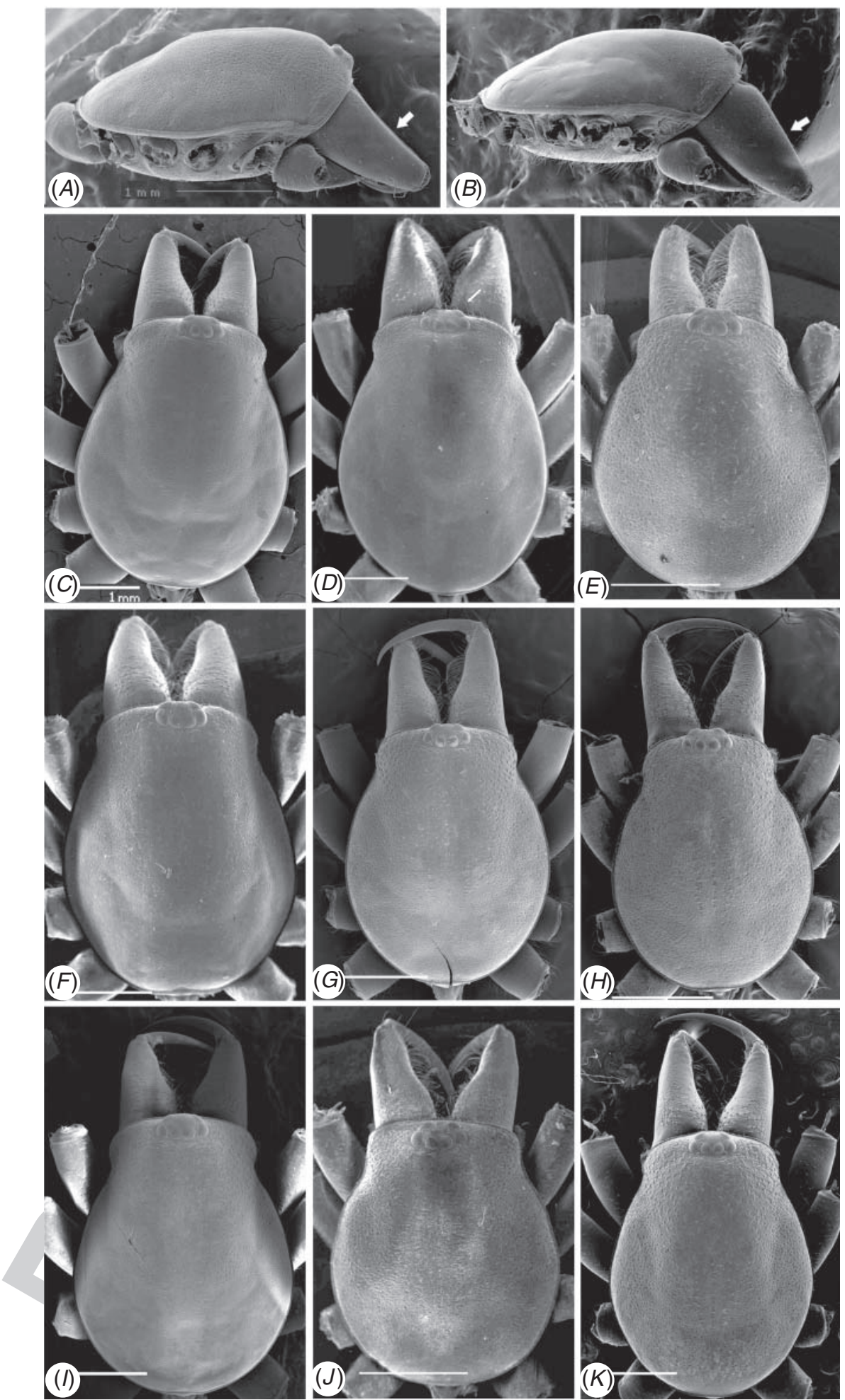

Fig. 2. Male prosomas (SEM). $(A, B)$ Lateral view; $(C-K)$ dorsal view. $(A, E)$ Dysdera cechica, sp. nov., Slovakia, Hrušov, the arrow points to the concave edge of the chelicera; $(B, F) D$. erythrina (Walckenaer, 1802), Czechia, Prague, the arrow points to the straight edge of the chelicera; $(C) D$. catalonica, sp. nov., Spain, Montseny, Turó de l'Home Mt.; $(D) D$. corallina Risso, 1826, France, Provence, the arrow points to the long setae on the clypeus; $(G) D$. garrafensis, sp. nov., Spain, Garraf; $(H) D$. portsensis, sp. nov., Spain, Ports de Beseit; (I) D. pradesensis, sp. nov., Spain, Montserrat; (J) D. stahlavskyi, sp. nov., France, Agay; $(K)$ D. undecimal, sp. nov., Spain, Montseny. Scale bar $=1 \mathrm{~mm}$. 

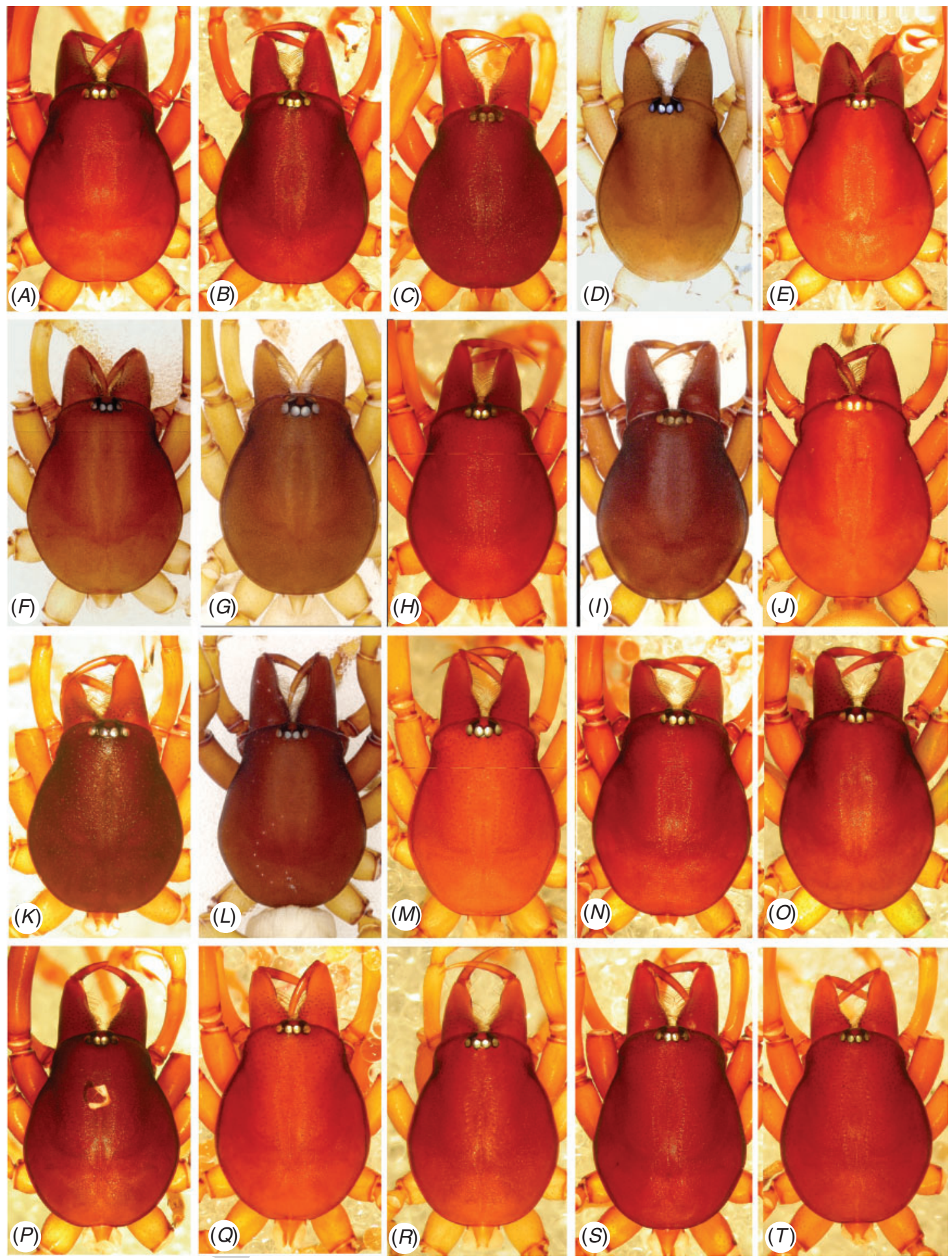

Fig. 3. Male prosomas (dorsal view, light microscopy). (A) Dysdera catalonica, sp. nov., Spain, Montseny; (B) D. corallina Risso, 1826, France, Provence; $(C)$ D. cechica sp. nov., Czechia, Drslavice; $(D)$ D. dolanskyi, sp. nov., Spain, Montblanc; $(E) D$. erythrina (Walckenaer, 1802), Czechia, Prague; $(F) D$. fabrorum sp. nov., Spain, Setcases; $(G) D$. fervida Simon, 1882, France, Corsica, Rogliano; (H) D. garrafensis, sp. nov., Spain, Garraf; (I) D. graia sp. nov., France, Hérault, Clauzels; (J) D. kropfi, sp. nov., Switzerland, Liesberg; $(K) D$. lantosquensis Simon, 1882, Italy, Genova; $(L) D$. minairo, sp. nov., Spain, Planes de Son; $(M) D$. portsensis, sp. nov., Spain, Ports de Beseit; $(N)$ D. pradesensis, sp. nov., Spain, Montserrat; $(O)$ D. pyrenaica, sp. nov., Spain, Pyrenees, Riu de Cerdanya; $(P) D$. quindecima, sp. nov., Spain, Montseny; $(Q) D$. septime, sp. nov., Spain, Montseny; $(R) D$. stahlavskyi, sp. nov., France, Agay; $(S)$ D. tredecima, sp. nov., Spain, Montseny; (T) D. undecimal, sp. nov., Spain, Montseny. 
The tibiae and metatarsi of the third and fourth legs have several short, strong spines (detailed in Appendix 1). The femora are spineless.

Opisthosoma. Cylindrical, whitish. Abdominal dorsal hairs 5 usually long $(\sim 0.08 \mathrm{~mm})$ and more or less clavated (Fig. $4 A, B)$. In adult males of some species they are short $(\sim 0.02 \mathrm{~mm}$; Fig. $4 C, D)$.

Bulb (Figs 1A, 5-11). Bulb 0.9-1.6 mm long; the ratio distal division length/bulb length is $0.43-0.54$ (distal division length shown in Fig. 1A). Tegulum and distal division anterior margins are angled or almost straight in retrolateral view (Figs 5, 7). The distal half of tegulum in retrolateral view is as wide as (e.g. Fig. $7 E$ ) or wider than its proximal half (e.g. Fig. $7 F$ ). On the very distal edge of the tegulum, on the posterior margin, there is a heavily sclerotised triangular posterior apophysis, which is 15 obtuse (e.g. Fig. 10O) or pointed (e.g. Fig. 10S), and of varying size relative to the whole bulb. In some species, the proximal side of the posterior apophysis is equipped with an additional tooth (e.g. Fig. 11A). Proximally from the posterior apophysis, there is a smooth (e.g. Fig. $7 F$ ) or striated lump (e.g. Fig. $7 G$ ) of variable tegulum, gives the tegulum a bituberculate appearance in retrolateral view.

The distal division is composed of a membranous haematodocha and a bifurcated sclerite. The external branch of this sclerite forms a lateral sheet, whereas the internal branch broadens at its apical end. From this structure, a small sub-branch carrying a membranous sheet called the distal projection runs towards the apical end of the lateral sheet. Between the lateral sheet and the distal projection there is a small gap (fissure), which is more (e.g. Fig. $7 E$ ) or less covered by the lateral sheet. This lateral sheet projects distally and is either parallel (e.g. Fig. $7 B$ ) or at an angle (e.g. Fig. $7 C$ ). The apical part of the distal projection is either suddenly or gradually bent down (e.g. Fig. 7B, arrow). The opening of the sperm duct is located between the apical part of the lateral sheet and this distal projection. The margin of the distal division, opposite the lateral sheet, is composed of a haematodocha with tiny proximally pointing (reverse) teeth. Distal division ends in an arch-like ridge. When looking to the bulb from above (when the posterior apophysis is close to the observer-hind view, see Fig. 8), the proximal part of the arch-like
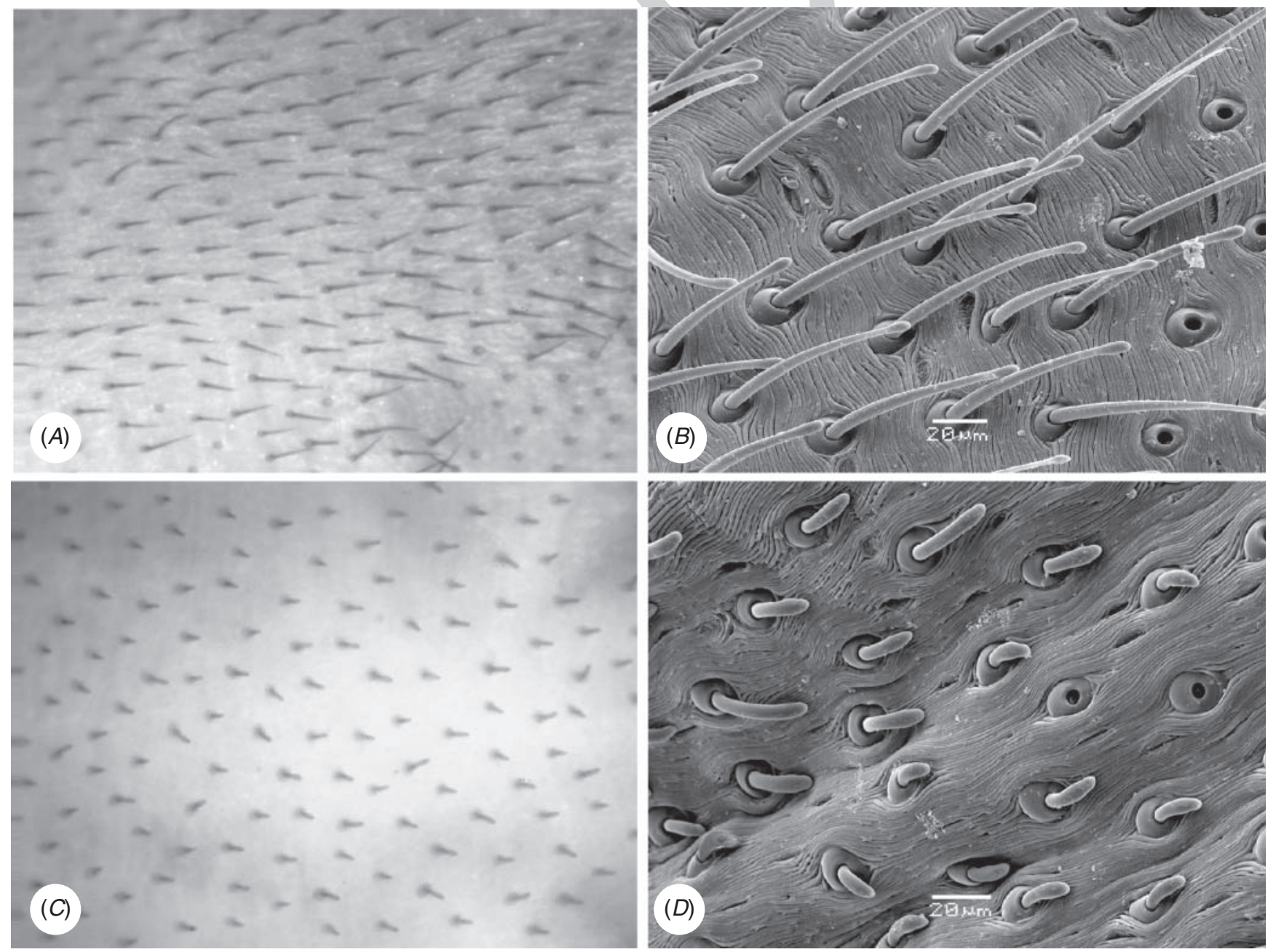

Fig. 4. Adult males, hairs on the dorsal side of opisthosoma. $(A, C)$ Light microscopy images; $(B, D)$ SEM images. $(A, B) D y s d e r a$ cechica, sp. nov., Czechia, Drslavice; $(C, D)$ D. erythrina (Walckenaer, 1802), Czechia, Králův Dvůr. 

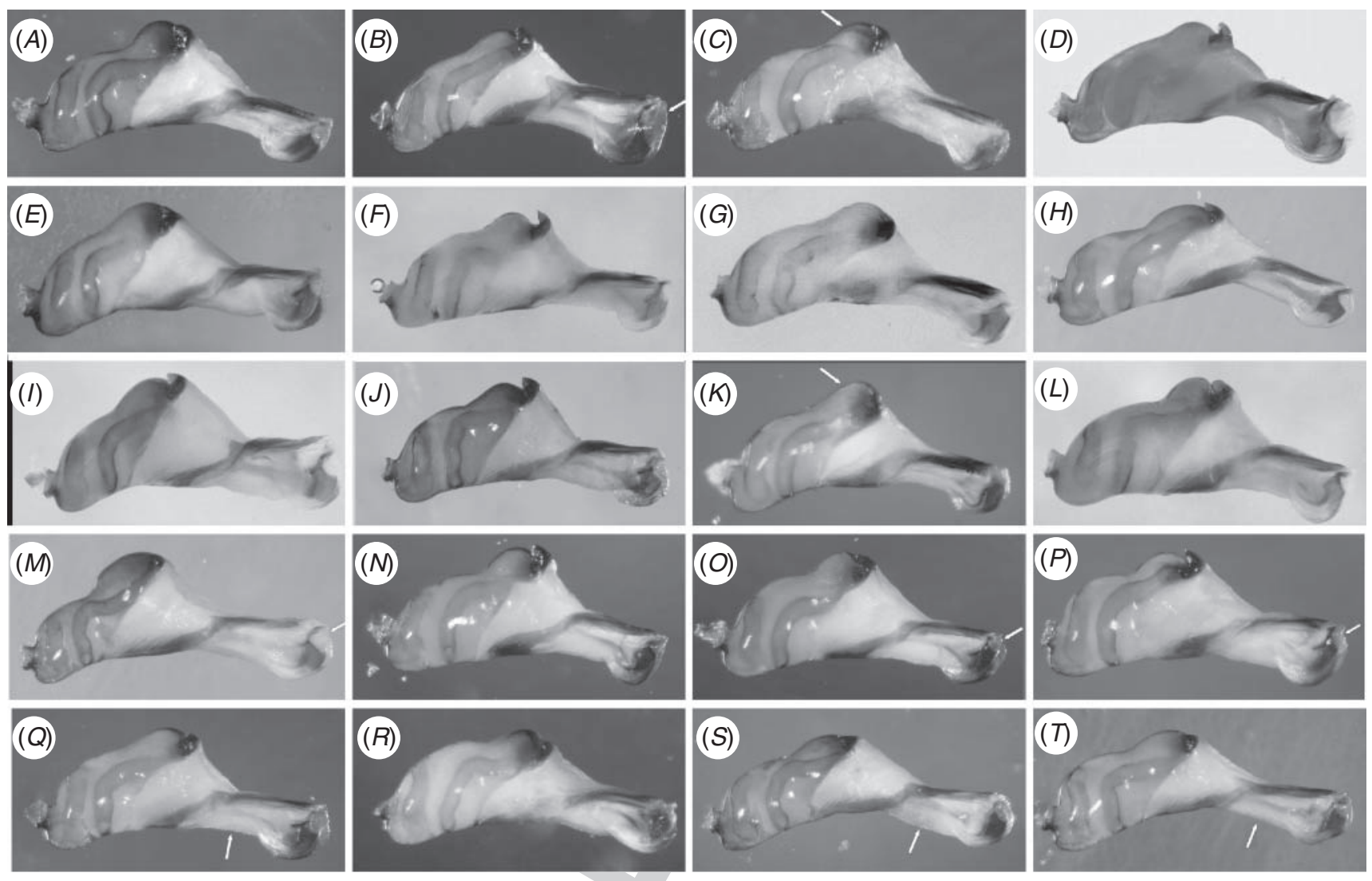

Fig. 5. Left male bulb (retrolateral view, light microscopy). (A) Dysdera catalonica, sp. nov., Spain, Montseny; (B) D. corallina Risso, 1826, France, Provence, the arrow points to the very large membranous patch; $(C) D$. cechica, sp. nov., Czechia, Drslavice, the arrow shows a diagnostic of the relatively narrow distal half of tegulum; (D) D. dolanskyi, sp. nov., Spain, Montblanc; (E) D. erythrina (Walckenaer, 1802), Czechia, Prague; (F) D. fabrorum sp. nov., Spain, Setcases; (G)D.fervida Simon, 1882, France, Corsica, Rogliano; (H) D. garrafensis, sp. nov., Spain, Garraf; (I) D. graia, sp. nov., France, Hérault, Clauzels; (J)D. kropfi, sp. nov., Switzerland, Liesberg; $(K) D$. lantosquensis Simon, 1882, Italy, Genova, the arrow points to the high lump, making the distal half of tegulum markedly wider than its proximal half; $(L) D$. minairo, sp. nov., Spain, Planes de Son; $(M) D$. portsensis, sp. nov., Spain, Ports de Beseit, the arrow points to the large membranous patch; $(N)$ D. pradesensis, sp. nov., Spain, Montserrat; $(O)$ D. pyrenaica, sp. nov., Spain, Pyrenees, Riu de Cerdanya, the arrow points to the membranous patch that is larger than in $D$. pradesensis, but smaller than in D. erythrina; $(P) D$. quindecima, sp. nov., Spain, Montseny, the arrow points to the membranous patch that is smaller than in D. erythrina; $(Q) D$. septime, sp. nov., Spain, Montseny, the arrow points to the margin of the distal division that is not convex; $(R) D$. stahlavskyi sp. nov., France, Agay; (S) Dysdera tredecima, sp. nov., Spain, Montseny, the arrow points to the margin of the distal division that is convex; (T) D. undecimal, sp. nov., Spain, Montseny, the arrow points to the straight haematodocha.

ridge protrudes from the bulb outline gradually (e.g. Fig. $8 S$, arrow) or almost at a right angle (e.g. Fig. $8 O$, arrow). Close to the lateral sheet, a small part of the arch-like ridge is membranous (membranous patch, MP in Fig. 1A).

Vulva (Figs $1 B, 12)$. Spermatheca $0.61-0.76 \mathrm{~mm}$ long; the anterior margin in dorsoventral view appears convex (e.g. Fig. 12E), straight or concave (e.g. Fig. 12C), and the lateral parts extend directly to the side (e.g. Fig. 12B) or are incurvated backwards (e.g. Fig. 12I). In some species, they are more

10 retroventrally bulging, which appears as 'folds' (retroventral folds, RF) in ventral view (e.g. Fig. 12C). The anterior lateral sides of the spermatheca are equipped with sclerotised (e.g. Fig. 12D, upper arrow, $12 U$ ) or inconspicuous tooth-like muscle anchors. In dorsoventral view, the anterior margin of 15 the dorsal arch is either regularly round (e.g. Fig. 12D) or almost straight (e.g. Fig. 12F), or in some species has shoulder-like lateral lobes (LL; e.g. Fig. 12C). The ventral wall has either conspicuous (e.g. Fig. 12D, lower arrow) or inconspicuous transversal furrows (e.g. Fig. 12E) and on its inner side there is a medial groove leading to the spermatheca, which can be simple (e.g. Fig. 12U) or with sclerotised spicules (Fig. 12B, arrow, 12T) or pupiles (Fig. 12E, arrow).

\section{Functional morphology of the copulatory organs}

During copulation, both bulbs are inserted into the vulva simultaneously. By inserting the bulbs, the posterior diverticle, a pocket that typically lies behind the epigastric furrow, expands and is pulled in front of the epigastric furrow. In this way, the copulatory bursa is significantly enlarged, completely enclosing the distal divisions of both bulbs. The expansion of the copulatory bursa is further allowed by the flexuous lateral walls, where folded sclerotised and membranous parts alternate like an accordion. The posterior apophyses are hooked to the posterior 
edge of the epigastric furrow; the distal division lies between the sclerotised dorsal arch (posteriorly attached to inflated posterior diverticle) and the membranous ventral wall. The opening of the sperm duct falls close to the opening of the channel leading to the

5 spermatheca, while the frontal lobe of the arch-like ridge of the bulb pokes at the ventral wall. The haematodochae of the distal divisions are equipped with a number of small reverse teeth, which, together with the posterior apophysis, probably help to lock the bulbs inside the vulva.

\section{Morphological diagnostic differences of species}

The body size and colour, carapace shape and sculpture, relative length and chaetotaxy of legs, as well as the shape and morphology of the mouthparts and the genitalic organs are specific to each species. See Appendix 1 for a detailed list of diagnostic characters.

\section{Remarks}

The taxonomic category 'species-group', traditionally used in Dysdera (introduced by Deeleman-Reinhold and Deeleman 1988), is superior to the species-complex. The species-group

20 also contains more evolutionarily distant species that clearly differ in morphology. Deeleman-Reinhold and Deeleman (1988) established the D. erythrina-group to include D. erythrina and some other species from the Iberian Peninsula; in particular, D. fuscipes Simon, 1882, D. anonyma 25 Ferrández, 1984 and D. veigai Ferrández, 1984. Species of this group shared a depressed anterior carapace, concave chelicerae, spineless femora and a male bulb lacking lateral projection. Subsequently, Arnedo et al. (2009) described two additional species in the $D$. erythrina-group endemic to Sardinia, namely,

30 D. shardana Opatova \& Arnedo, 2009 and D. jana Gasparo \& Arnedo, 2009. A multilocus phylogenetic analysis confirmed that the two new species were closely related to $D$. erythrina, $D$. fervida and D. lantosquensis, but that the Iberian species originally suggested by Deeleman-Reinhold and Deeleman (1988) were not (Arnedo et al. 2009). They referred to the clade including the species $D$. erythrina, $D$. fervida, $D$. jana and $D$. shardana as the $D$. erythrina species-complex, and proposed genitalic traits, in particular the large, semicircular expansion (AR in Fig. 1) at the distal male bulb and the 40 bilobular, granulated posterior diverticulum in the female vulva as its main synapomorphies. They further suggested the existence of a more inclusive lineage, including $D$. erythrina, characterised by the particular shape of the tegulum with a mid-part constraint and an expansion around the posterior 5 apophysis $(\mathrm{P})$ region. Here, we describe 16 new species and redescribe four previously known species belonging to the D. erythrina-complex: $D$. catalonica, sp. nov., D. corallina Risso, 1826, D. cechica, sp. nov., D. dolanskyi, sp. nov., D. erythrina, D. fabrorum, sp. nov., D. fervida,

50 D. garrafensis, sp. nov., D. graia, sp. nov., D. kropfi, sp. nov., D. lantosquensis, D. minairo, sp. nov., D. portsensis, sp. nov., D. pradesensis, sp. nov., D. pyrenaica, sp. nov., D. quindecima, sp. nov., D. septima, sp. nov., D. stahlavskyi, sp. nov., D. tredecima, sp. nov. and D. undecima, sp. nov.
Dysdera catalonica Řezáč, sp. nov.

(Figs $2 C, 3 A, 5 A, 6 A, 7 A, 8 A, 9 A, 10 A, 11 A, 12 A, 13,14,15 B$ )

http://zoobank.org/urn:lsid:zoobank.org:act:6F80228A-7F33-45499C27-CFB79B9BE823

\section{Material examined}

Holotype. $\quad \hat{\jmath}$, Spain: Catalonia: Montseny Natural Park, Camping Can Cervera near Montseny town, $41.774^{\circ} \mathrm{N}, 2.411^{\circ} \mathrm{E}$, Quercus forest, 9-10. ix.2006, M. Řezáč (NMPC).

Paratypes. Spain: Catalonia: Barcelona: Montseny Natural Park, Camping Can Cervera near Montseny town, $41.774^{\circ} \mathrm{N}, 2.411^{\circ} \mathrm{E}$, Quercus forest, 2 đิ, 8 q, 1 juv., 9-10.ix.2006, 1 q, 30.iv.2009, M. Řezáč (MR); Montseny Natural Park, Camping Les Piscines, $41.75916^{\circ} \mathrm{N}, 2.3893^{\circ} \mathrm{E}, 1$ ô, 18.iv.2008, S. Carranza (CRBA VO141); Montseny Natural Park, Font de Passavets, Santa Fe, $41.78083^{\circ}$ N, $2.45222^{\circ} \mathrm{E}, 1$ ô, 11.iv.2008, M. Arnedo, V. Opatova, L. Bidegaray-Batista and N. Macías-Hernández (CRBA VO000125); 1 ô (CRBA VO000132); Montseny Natural Park, Turó de l'Home Mt., $41.777^{\circ} \mathrm{N}, 2.445^{\circ} \mathrm{E}$, Abies forest, 1 q, 10.ix.2006, 5 ๙ै, 1 q, 30.iv.2009, M. Rezáč (MR); Montseny Natural Park, Turó de l'Home, along road to Sant Celoni, 1 \&, 9.vi.2002, E. De Mas (CRBA VO000039); Cantonigros, between Vic and Olot, $42.075^{\circ} \mathrm{N}, 2.484^{\circ} \mathrm{E}$, Fagus forest, 1 oे, 10.ix.2006, F. Št áhlavský (MR).

Other material. See Supplementary material file.

Diagnosis

Dysdera catalonica is very similar to $D$. corallina. Both these species are large, possess a dark carapace (Fig. $3 A, B$ ), and distal projection of the bulb forms a rounded membranous lobe in its apical part, which is visible in frontal view (Figs 9A, $B, 11 A, B$, arrows). Dysdera catalonica differs from $D$. corallina in several aspects: (1) the carapace is reddish brown, smoother and relatively shorter (Figs $2 C, 3 A ; D$. corallina: Figs $2 D, 3 B$ ); (2) spines on the ventral side of leg IV tibia are more numerous (five or six: two proventral, one retroventral, two or three ventral); (3) the membranous patch of the male bulb is smaller (Fig. $5 A$; D. corallina: Fig. $5 B$ ) and the distal projection is suddenly bent down; and (4) the vulva is without sclerotised spicules along the medial groove (D. corallina: Fig. $12 T)$ and the spermatheca has a concave anterior margin (Fig. 12A, arrow) (in D. corallina it is straight or slightly convex: Fig. 12B).

\section{Description}

Features common to all species of the complex are specified in the general description of the complex above; for descriptions of particular species see Appendix 1. The tabular presentation of descriptions is non-traditional, but it allows easy comparison.

\section{Intraspecific variation}

Carapace length $3.6-4.9 \mathrm{~mm}$; five or six spines on ventral 45 (including proventral and retroventral) side of leg IV tibia; bulb length $1.35-1.69 \mathrm{~mm}$; spermatheca width $0.61-0.76 \mathrm{~mm}$.

\section{Habitat}

Various types of forest on mountain slopes. 

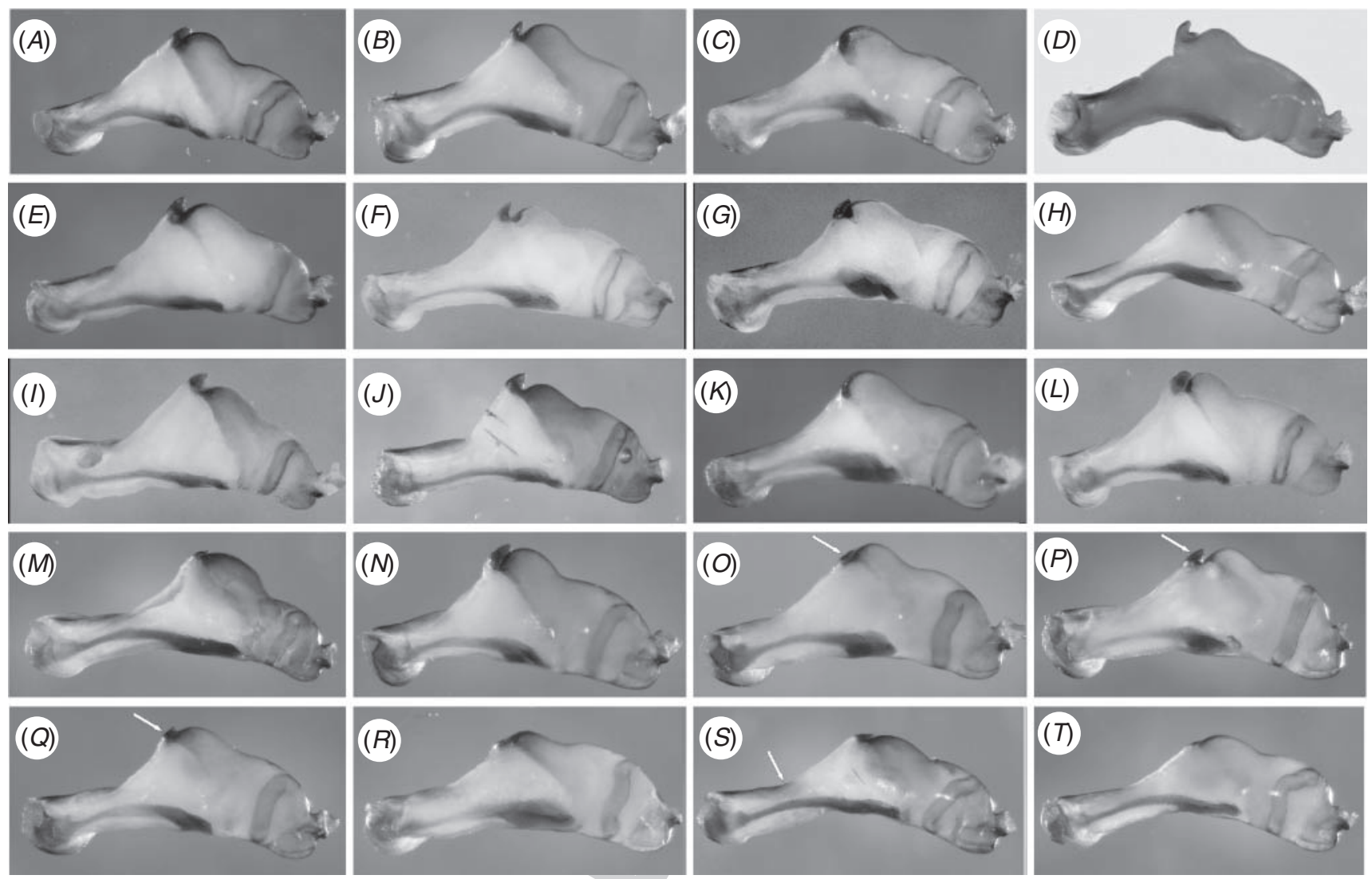

Fig. 6. Left male bulb (prolateral view, light microscopy). (A) Dysdera catalonica, sp. nov., Spain, Montseny; (B) D. corallina Risso, 1826, France, Provence; (C) D. cechica, sp. nov., Czechia, Drslavice; (D) D. dolanskyi, sp. nov., Spain, Montblanc; (E) D. erythrina (Walckenaer, 1802), Czechia, Prague; (F) D. fabrorum sp. nov., Spain, Setcases; $(G)$ D. fervida Simon, 1882, Corsica, Rogliano; $(H)$ D. garrafensis, sp. nov., Spain, Garraf; (I) Dysdera graia, sp. nov., France, Hérault, Clauzels; $(J)$ D. kropfi, sp. nov., Switzerland, Liesberg; $(K)$ D. lantosquensis Simon, 1882, Italy, Genova; $(L)$ D. minairo, sp. nov., Spain, Planes de Son; (M) D. portsensis, sp. nov., Spain, Ports de Beseit; $(N)$ D. pradesensis, sp. nov., Spain, Montserrat; $(O)$ D. pyrenaica, sp. nov., Spain, Pyrenees, Riu de Cerdanya, the arrow points to the distally placed posterior apophysis that does not exceed the lump; $(P) D$. quindecima, sp. nov., Spain, Montseny, the arrow points to the posterior apophysis that is placed more distally than in D. erythrina; $(Q) D$. septime, sp. nov., Spain, Montseny, the arrow points to the posterior apophysis that does not exceed the lump; $(R) D$. stahlavskyi, sp. nov., France, Agay; $(S)$ D. tredecima, sp. nov., Spain, Montseny, the arrow points to the small angle between the haematodocha and the lateral sheet; $(T) D$. undecimal, sp. nov., Spain, Montseny.

\section{Distribution}

Dysdera corallina is found in Catalonia on the north-eastern Iberian Peninsula, southern France (revised material) and the Apennines in Italy (Simon 1914) (Fig. 13).

\section{Etymology}

Named after Catalonia, the autonomous Spanish region where the majority of specimens of this species were collected.

\section{Dysdera cechica Řezáč, sp. nov.}

(Figs $2 A, E, 3 C, 4 A, B, 5 C, 6 C, 7 C, 8 C, 9 C, 10 C, 11 C, 12 C, 13$, $14,15 E)$

http://zoobank.org/urn:lsid:zoobank.org:act:EAAC9428-A082-4211A043-3CBC50AA1E68

Dysdera erythrina (Walckenaer): Loksa, 1969: 75, figs 52C, D, 53F (370);

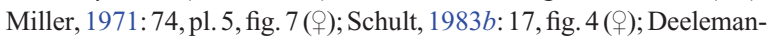
Reinhold \& Deeleman, 1988: 164, figs 12, 44-49 (ふ̋+o); Heimer \&

Nentwig, 1991: 44, fig. 95.1 (ふో) (misidentifications).

Dysdera lantosquensis Simon: Řezáč et al., 2007: 455-457.

\section{Material examined}

Holotype. Ô, Czechia: Ráby, Kunětická hora Mt., $50.0796^{\circ} \mathrm{N}$, $15.8121^{\circ} \mathrm{E}$, bush on gravel under the castle ruin, 4.v.- 18.vi.1997, pitfall trap, J. Dolanský (EBH).

Paratypes. Czechia: Bohemia: Hradčany, reserve Báň, $50.1587^{\circ} \mathrm{N}$, 5 $15.2777^{\circ} \mathrm{E}$, marl slope, 3 ô, 1 ㅇ, 2.v.-3.vi.2002, pitfall traps, J. Dolanský (EBH); Žehuň, reserve Kněžičky, $50.1535^{\circ} \mathrm{N}, 15.3132^{\circ} \mathrm{E}$, thermophilous Quercus forest, 1 + , 26.v.1961, 1 ô, 4.vi.1968, J. Buchar (coll. J. Svatoň); Ráby, castle Kunětická hora, $50.0796^{\circ} \mathrm{N}, 15.8121^{\circ} \mathrm{E}$, bush on gravel under the castle ruin, 1 ô, 2 क, 4.v.-18.vi.1997, pitfall traps, J. Dolanský, 1 ô, 19.iv.2003, J. Dolanský and M. Řezáč (MR); České Lhotice, reserve Krkanka, $49.8627^{\circ} \mathrm{N}, 15.7824^{\circ} \mathrm{E}$, stony slope partly covered by trees, 1 ô, 11 .vi.1.viii.2008, pitfall traps, J. Dolanský (EBH); Žumberk, $49.8764^{\circ} \mathrm{N}$, $15.8556^{\circ} \mathrm{E}$, dry thermophilous Quercus wood with Calluna, 2 ô, 7.v.10.vii.1996, pitfall traps, J. Dolanský (MR). Moravia: Staré Oldřùvy, valley of the river Odra, $49.7355^{\circ} \mathrm{N}, 17.6761^{\circ} \mathrm{E}$, Quercus-Carpinus forest, 1 o, 28.v.2006, pitfall traps, Š. Gruchala (coll. Š. Gruchala); Teplice nad Bečvou, near the entrance of the Zbrašovské jeskyně caves, $49.5319^{\circ} \mathrm{N}$, $17.7458^{\circ} \mathrm{E}$, forest on stony slope, 2 +, 21 .iv.-31.v.2004, pitfall traps, K. Tajovský and I. Tuf (MR); Blansko, $49.3628^{\circ} \mathrm{N}, 16.6597^{\circ} \mathrm{E}, 1$ ô, 1 \%, 15.v.1979, F. Miller (NMP); Vilémovice, $49.3670^{\circ} \mathrm{N}, 16.7409^{\circ} \mathrm{E}, 1$ ㅇ, 28.ix.2004, pitfall trap, J. Vašátko (MR); Těchov, reserve Vývěry Punkvy, 

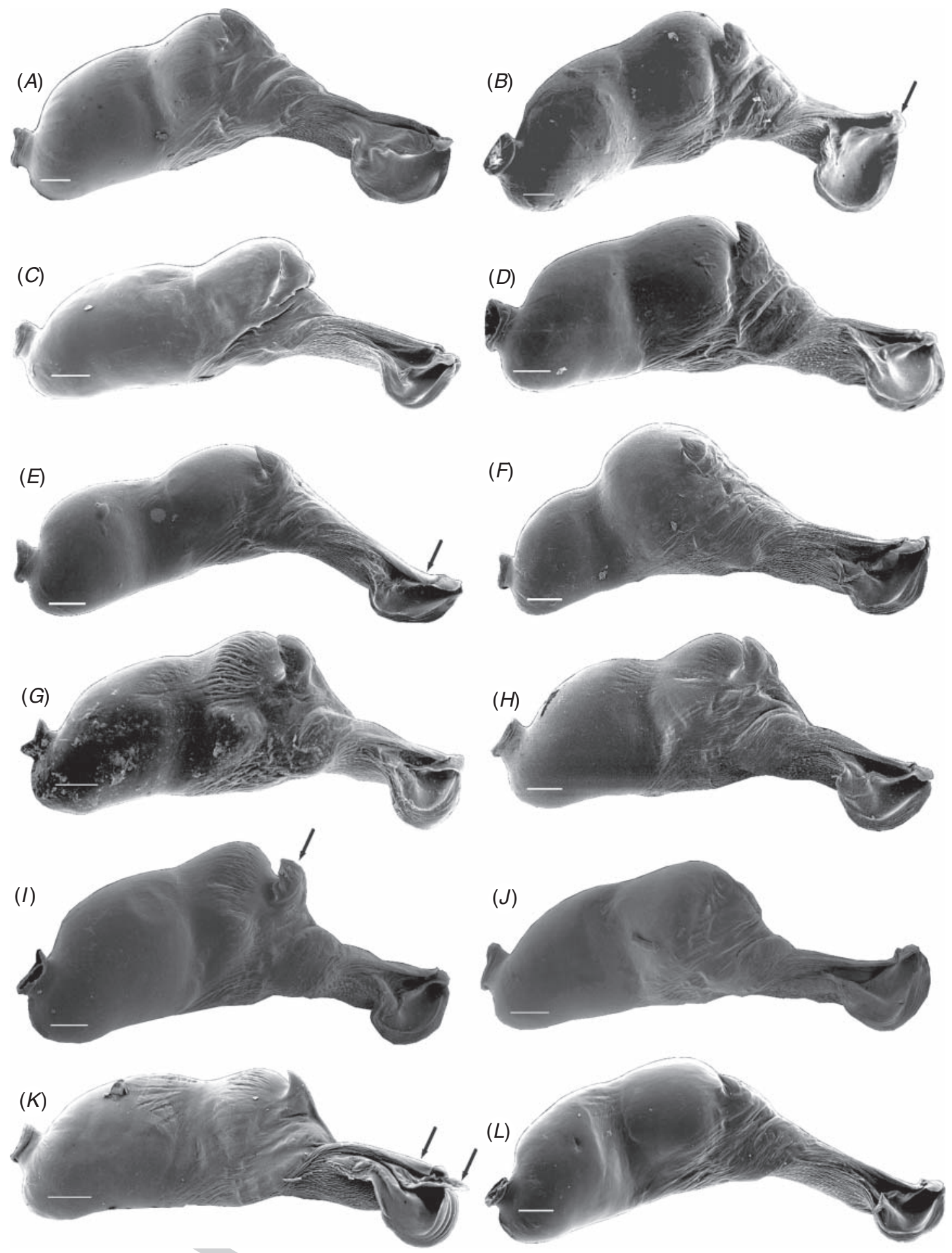

Fig. 7. Left male bulb (retrolateral view, SEM). (A) Dysdera catalonica, sp. nov., Spain, Montseny, Turó de l'Home; (B) D. corallina Risso, 1826, France, Provence, the arrow points to the characteristic lobe formed by the distal projection; $(C) D$. cechica, sp. nov., Slovakia, Hrušov; (D) D. erythrina (Walckenaer, 1802), Czechia, Prague; (E) D. garrafensis, sp. nov., Spain, Garraf, the arrow points to the distal projection partly covering the fosette; $(F) D$. portsensis, sp. nov., Spain, Ports de Beseit; $(G) D$. pradesensis, sp. nov., Spain, Montserrat; $(H)$ D. pyrenaica, sp. nov., Spain, Pyrenees, Riu de Cerdanya; $(I) D$. quindecima, sp. nov., Spain, Montseny, the arrow points to the markedly distally placed posterior apophysis; $(J) D$. septima, sp. nov., Spain, Montseny; $(K) D$. stahlavskyi, sp. nov., France, Agay, the left arrow points to the lobe on the distal projection, the right arrow points to the protrusion of the distal projection; $(L)$ D. undecima, sp. nov., Spain, Montseny. Scale bar $=0.1 \mathrm{~mm}$. 

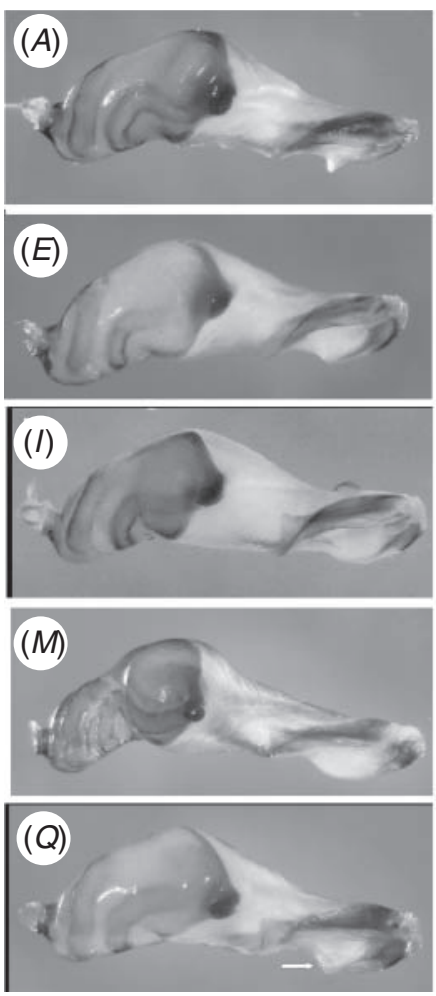
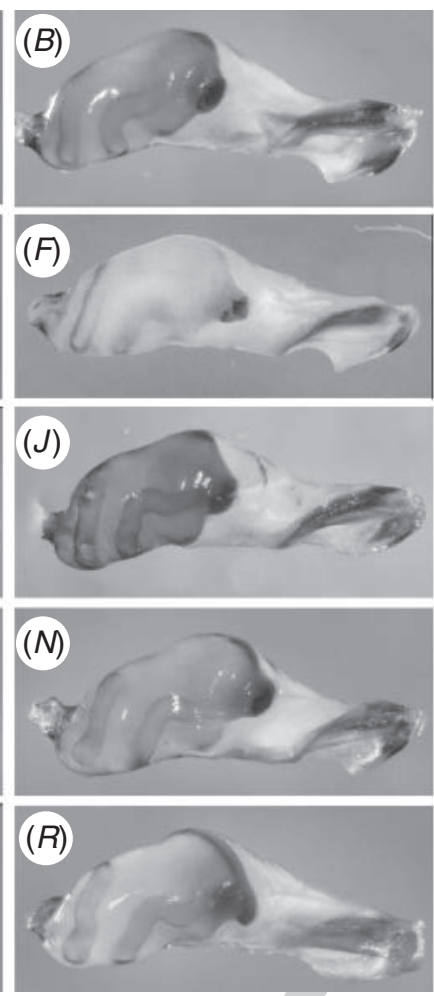
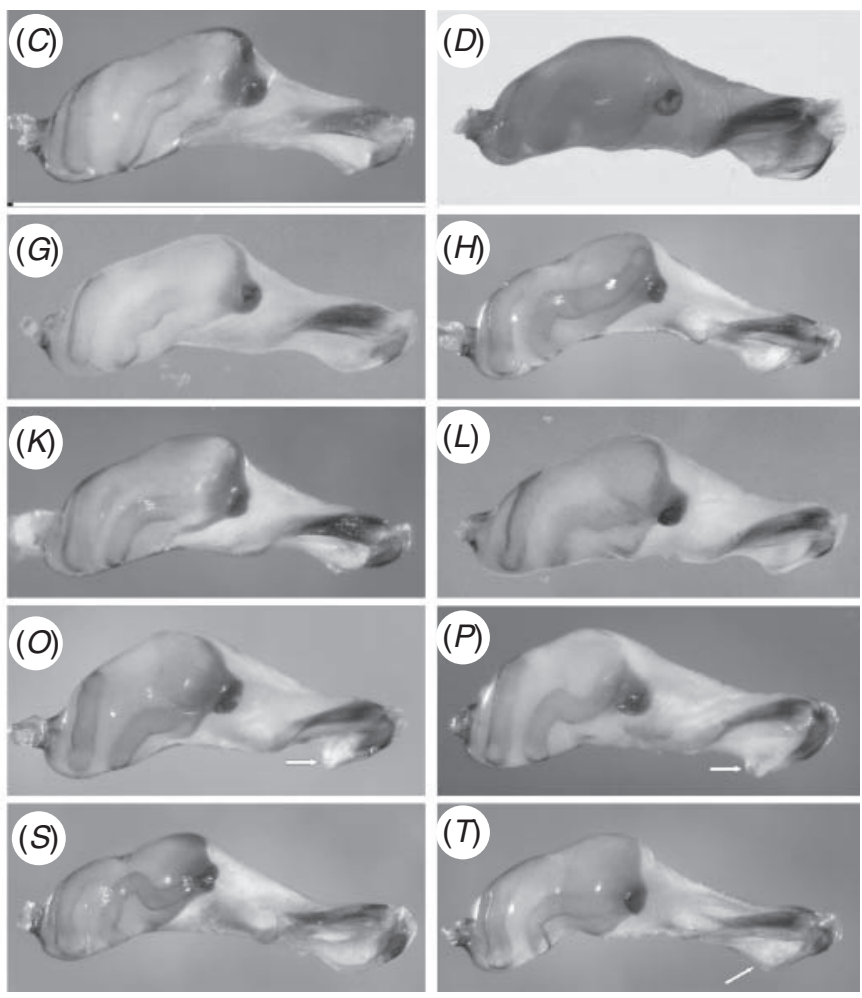

Fig. 8. Left male bulb (hind view, light microscopy). (A) Dysdera catalonica, sp. nov., Spain, Montseny; (B) D. corallina Risso, 1826, France, Provence; (C)D. cechica, sp. nov., Czechia, Drslavice; (D) D. dolanskyi, sp. nov., Spain, Montblanc; (E) D. erythrina (Walckenaer, 1802), Czechia, Prague; $(F) D$. fabrorum, sp. nov., Spain, Setcases; $(G) D$. fervida Simon, 1882, France, Corsica, Rogliano; $(H) D$. garrafensis, sp. nov., Spain, Garraf; (I) D. graia, sp. nov., France, Hérault, Clauzels; $(J) D$. kropfi, sp. nov., Switzerland, Liesberg; $(K)$ D. lantosquensis Simon, 1882, Italy, Genova; $(L)$ D. minairo, sp. nov., Spain, Planes de Son; (M) D. portsensis, sp. nov., Spain, Ports de Beseit; $(N)$ D. pradesensis, sp. nov., Spain, Montserrat; $(O)$ D. pyrenaica, sp. nov., Spain, Pyrenees, Riu de Cerdanya, the arrow points to the proximal part of the arch-like ridge that protrudes from the outline of the bulb almost at right angles; $(P) D$. quindecima, sp. nov., Spain, Montseny, the arrow points to the proximal part of arch-like ridge that protrudes from the outline of the bulb almost at right angles; $(Q) D$. septima, sp. nov., Spain, Montseny, the arrow points to the proximal part of arch-like ridge, that protrudes from the outline of the bulb almost at right angles; $(R) D$. stahlavskyi, sp. nov., France, Agay; (S) D. tredecima, sp. nov., Spain, Montseny; (T) D. undecima, sp. nov., Spain, Montseny.

chasm Macocha, $49.3734^{\circ} \mathrm{N}, 16.7300^{\circ} \mathrm{E}$, sunny rocks in Fagus forest, 2 , 22.v.-13.vi.2008, pitfall traps, V. Rủžička (coll. V. Rủžička); Brno, reserve Obřanská strán̆, $49.2259^{\circ} \mathrm{N}, 16.6636^{\circ} \mathrm{E}$, steppe grassland with bush, 1 q, 10.vi.2007, pitfall trap, S. Vinkler (coll. V. Bryja); Brno, Hádky, 5 valley between Ochoz and Hostěnice, $49.2507^{\circ} \mathrm{N}, 16.7648^{\circ} \mathrm{E}, 1$, 5.vi.unknown year, F. Miller (NMP); Mohelno, reserve Mohelenská hadcová step, $49.1061^{\circ} \mathrm{N}, 16.1872^{\circ} \mathrm{E}, 1$ ○ิ, 1983, F. Miller (NMP), forest fringe, 1 ô, 10.v.1995, rocky steppe, 1 ô, 12.vi.1995, pitfall traps, J. Buchar (NMP); Střelice u Brna, reserve Strelický les, $49.1361^{\circ} \mathrm{N}, 16.5108^{\circ} \mathrm{E}$,

10 Quercus-Carpinus forest, 1 \% , 28.iv.1999, V. Bryja (MR); Bučovice, reserve Malhotky, $49.1484^{\circ} \mathrm{N}, 17.0543^{\circ} \mathrm{E}$, steppe grassland with bush,

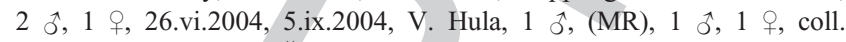
V. Hula; Dambořice, Ždánický les, $49.0417^{\circ} \mathrm{N}, 16.9244^{\circ} \mathrm{E}, 1$ ô, 30. vi.1967, F. Miller (NMP); Hradčovice, reserve Terasy, $49.0574^{\circ} \mathrm{N}$,

$1517.6011^{\circ} \mathrm{E}$, steppe grassland with bush, 4 ô, 2 क , 1 juv., 2.vi.2005, 8.viii.2005, 15.ix.2005, pitfall traps, Z. Majkus (coll. Z. Majkus); Hradčovice, reserve Rovná hora, $49.0691^{\circ} \mathrm{N}, 17.5893^{\circ} \mathrm{E}$, steppe grassland with bush, 1 \& , 15.ix.2005, pitfall trap, Z. Majkus (MR); Pouzdřany, Kolby forest, $48.9548^{\circ} \mathrm{N}, 16.6303^{\circ} \mathrm{E}$, Quercus-Carpinus forest, 1 oै, 1 के, 16.v.-

20 12.vi.2004, 1 ठै, 1 + , 22.v.-12.vi.2005, pitfall traps, S. Vinkler(coll. V. Bryja); Pouzdřany, reserve Pouzdřanská step-Kolby, $48.9445^{\circ} \mathrm{N}, 16.6435^{\circ} \mathrm{E}$, steppe grassland with Stipa, 1 + , 25.x.1967, F. Miller (NMP); Žítková, reserve Hutě, $48.9913^{\circ} \mathrm{N}, 17.9079^{\circ} \mathrm{E}$, Carpinus and Acer wood surrounded by grassland, 1 วิ, 1 + , 15.vi.-19.vii.2008, pitfall traps, M. Soviš and I. Tuf (MR); Horní 25 Věstonice, reserve Děvín-Kotel-Soutěska, $48.8643^{\circ} \mathrm{N}, 16.6510^{\circ} \mathrm{E}, 1$ ㅇ, 15.vi.1956, F. Miller (NMP); stony debris on foothill, $1 \hat{\jmath}, 1$ q, 2.viii.2003, V. Bryja (MR); Horní Věstonice, reserve Děvín-KotelSoutěska, $49.7224^{\circ} \mathrm{N}, 14.3689^{\circ} \mathrm{E}$, forest on stony slope, 1 ô, 26.x.1992-14.v.1994, pitfall traps, V. Růžička (coll. V. Růžičcka); Bulhary, Milovický les, $48.4900^{\circ} \mathrm{N}, 16.4200^{\circ} \mathrm{E}$, sunny place in Quercus pubescens wood, 6 ô, 23.v.2005, 2 ô, 30.vii.2005, pitfall traps, L. Spitzer (coll. R. Tropek). Silesia: Bruntál, reserve Ptačí hora, $50.0294^{\circ} \mathrm{N}, 17.5430^{\circ} \mathrm{E}$, Fagus forest, 1 ㅇ, 19.v.1998, Z. Majkus (coll. J. Svatoň).

Other material. See Supplementary material file.

\section{Diagnosis}

Dysdera cechica appears to be one of the smallest species of the complex. Together with $D$. lantosquensis, D. chechia differs from the other Dysdera in that: (1) the carapace is dark brown (Fig. 3C; D. lantosquensis: Fig. $3 K$ ), relatively high (Fig. $2 A$ ), shorter and roughly wrinkled (Fig. 2E); (2) mediodorsally the basal cheliceral segment is very concave (Fig. $2 A$ ); (3) the posterior apophysis of the male bulb is relatively large, almost pointed (Fig. 10C; D. lantosquensis: Fig. $10 K)$, and curved, without a tooth on its proximal side (Fig. 11C; D. lantosquensis: Fig. 11K); finally, (4) the spermatheca has a very concave anterior margin, the lateral edges directing to the sides, and the folds on the lateral parts of the spermatheca are conspicuous when viewed ventrally (Fig. 12C; 

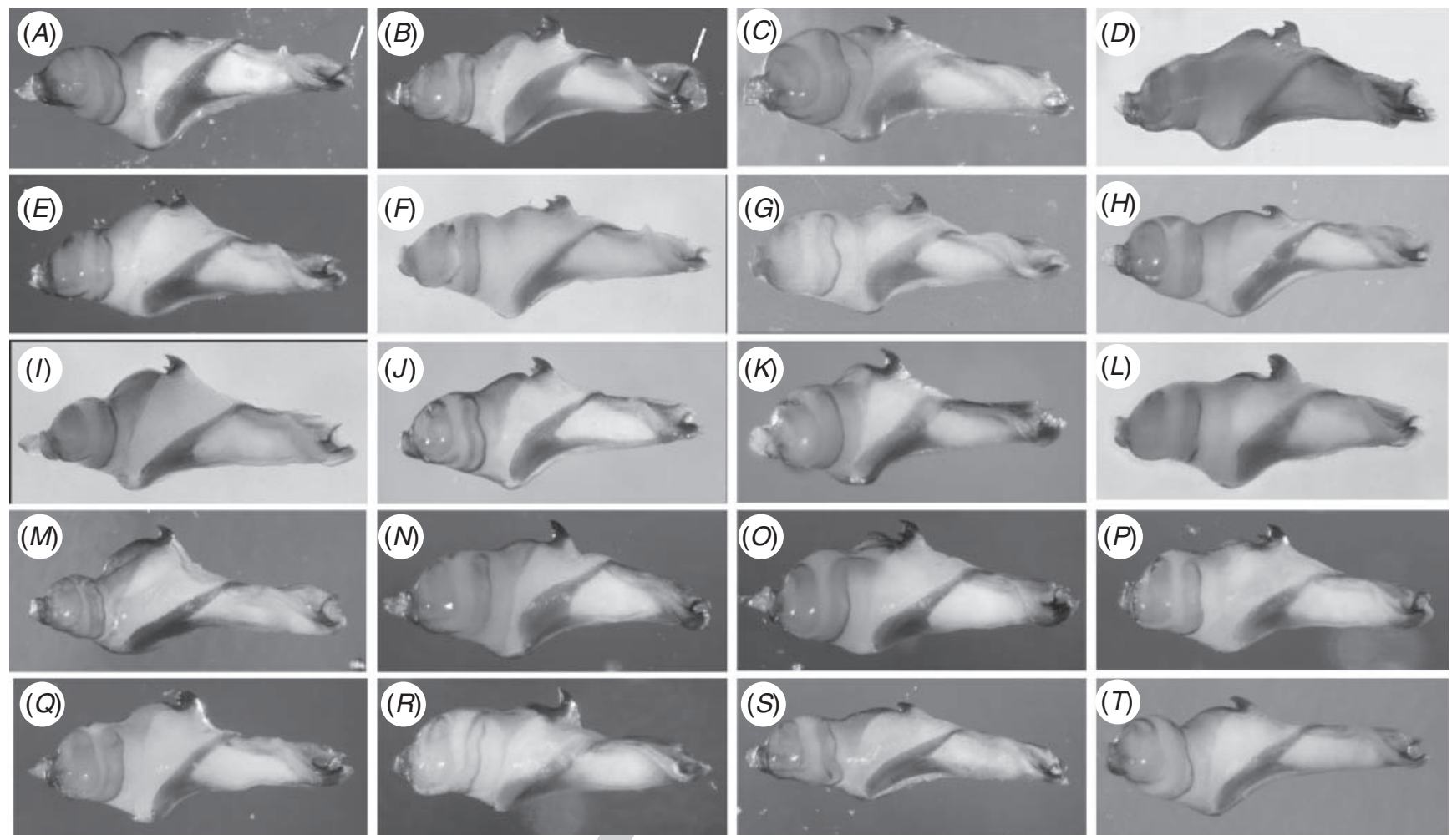

Fig. 9. Left male bulb (frontal view, light microscopy). (A) Dysdera catalonica, sp. nov., Spain, Montseny, the arrow points to the characteristic lobe; (B) D. corallina Risso, 1826, France, Provence, the arrow points to the lobe formed by the distal projection; $(C) D$. cechica, sp. nov., Czechia, Drslavice; (D) D. dolanskyi, sp. nov., Spain, Montblanc; $(E)$ D. erythrina (Walckenaer, 1802), Czechia, Prague; $(F) D$. fabrorum, sp. nov., Spain, Setcases; $(G) D$. fervida Simon, 1882, France, Corsica, Rogliano; (H) D. garrafensis, sp. nov., Spain, Garraf; (I) D. graia, sp. nov., France, Hérault, Clauzels; (J) D. kropfi, sp. nov., Switzerland, Liesberg; $(K)$ D. lantosquensis Simon, 1882, Italy, Genova; $(L) D$. minairo, sp. nov., Spain, Planes de Son; $(M) D$. portsensis, sp. nov., Spain, Ports de Beseit; $(N) D$. pradesensis, sp. nov., Spain, Montserrat; $(O) D$. pyrenaica, sp. nov., Spain, Pyrenees, Riu de Cerdanya; $(P) D$. quindecima, sp. nov., Spain, Montseny; $(Q) D$. septima, sp. nov., Spain, Montseny; $(R) D$. stahlavskyi, sp. nov., France, Agay; $(S) D$. tredecima, sp. nov., Spain, Montseny; $(T) D$. undecima, sp. nov., Spain, Montseny.

D. lantosquensis: Fig. 120). Adults possess long hairs on the dorsal side of the opisthosoma (Fig. 4A, B), similar to $D$. fervida, D. garrafensis, D. lantosquensis, D. portsensis and D. stahlavskyi. Dysdera chechia differs morphologically from

5 its sister species D. lantosquensis in the male bulb; the distal half of the tegulum is as wide as its proximal half (Fig. $5 C$; D. lantosquensis: Fig. $5 \mathrm{~K}$; arrows).

\section{Intraspecific variation}

Carapace length $2.1-3.6 \mathrm{~mm}$; three or four spines on the ventral

\section{Remarks}

Although this species has been collected many times, it has been commonly confused with $D$. erythrina (e.g. Deeleman-Reinhold and Deeleman 1988; Heimer and Nentwig 1991). The specimens to as D. lantosquensis in Řezáč et al. (2007) are actually members of the proposed species.

\section{Habitat}

In Czechia, this species occurs in xerothermic forests on 20 slopes (e.g. in plant communities of Carpinion, Quercion pubescenti-petraeae, Quercion petraeae, Genisto germanicaeQuercion and, less often, Fagion) and their fringes (Geranion sanguinei), in bushes (Berberidion) and in shaded parts of dry grasslands and heaths (Festucion valesiacae, Bromion erecti, Euphorbio-Callunion). It is also common in planted forests and semi-rural woods and bushes (often with Hedera helix on the ground), especially in areas surrounding ruins. Its occurrence is mainly concentrated in habitats enriched by calcium carbonate, which is essential for the proliferation of woodlice (Řezáč et al. 2007).

\section{Distribution}

Like D. erythrina, D. cechica is found across much of Europe, particularly central Europe (Fig. 13). It does not reach as far north as D. erythrina, but occurs further east. It is found in the eastern part of Austria, the eastern part of Czechia (see map in Rezáč 2012), Slovakia and Hungary. Because of its occurrence close to the borders between Czechia and Poland (Bruntál, $50.033^{\circ} \mathrm{N}$, $17.547^{\circ} \mathrm{E}$ ), Slovakia and Ukraine (Brekov, $48.902^{\circ} \mathrm{N}, 21.835^{\circ} \mathrm{E}$ ), and Hungary and Croatia (Pécs, $46.10^{\circ} \mathrm{N}, 18.22^{\circ} \mathrm{E}$ ) (Řezáč et al. 2007), it may also occur in southern Poland, the sub-Carpathian Ukraine and Croatia. Moreover, further migration can be expected due to its affinity with semi-rural habitats. 

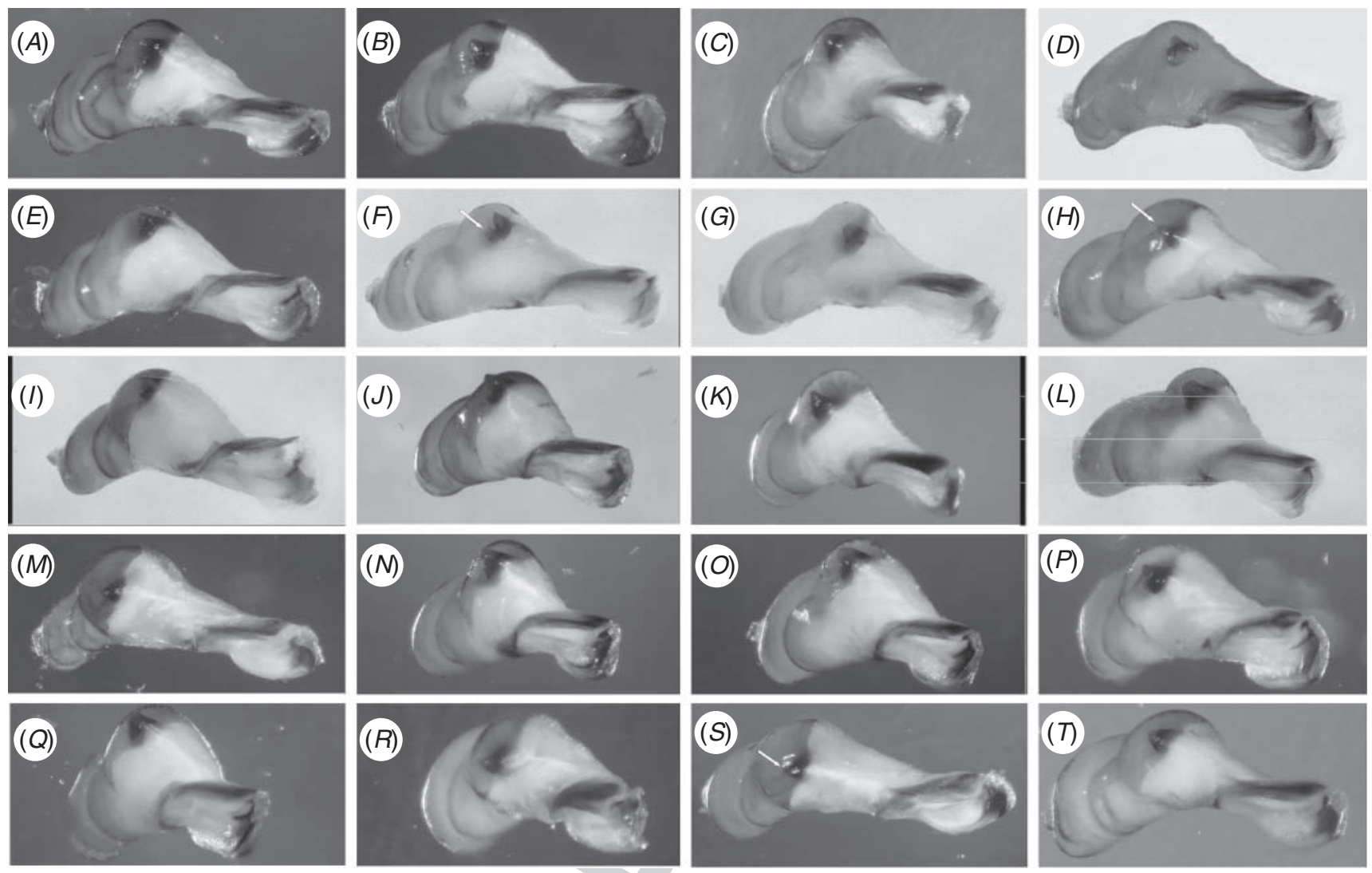

Fig. 10. Frontal view to the posterior apophysis of the left male bulb (light microscopy). (A) Dysdera catalonica, sp. nov., Spain, Montseny; (B) D. corallina Risso, 1826, France, Provence; $(C)$ D. cechica, sp. nov., Czechia, Drslavice; $(D)$ D. dolanskyi, sp. nov., Spain, Montblanc; (E) D. erythrina (Walckenaer, 1802), Czechia, Prague; $(F) D$. fabrorum, sp. nov., Spain, Setcases, the arrow points to the diagnostic bifurcate additional tooth of the posterior apophysis; $(G) D$. fervida Simon, 1882, France, Corsica, Rogliano; $(H) D$. garrafensis, sp. nov., Spain, Garraf, the arrow points to the pointed tip of the small posterior apophysis incurvated towards the prolateral side; (I) D. graia, sp. nov., France, Hérault, Clauzels; (J) D. kropfi, sp. nov., Switzerland, Liesberg; $(K)$ D. lantosquensis Simon, 1882, Italy, Genova; (L) D. minairo, sp. nov., Spain, Planes de Son; $(M)$ D. portsensis, sp. nov., Spain, Ports de Beseit; (N) D. pradesensis, sp. nov., Spain, Montserrat; $(O)$ D. pyrenaica, sp. nov., Spain, Pyrenees, Riu de Cerdanya; $(P) D$. quindecima, sp. nov., Spain, Montseny; $(Q) D$. septima, sp. nov., Spain, Montseny; (R) D. stahlavskyi, sp. nov., France, Agay; (S) D. tredecima, sp. nov., Spain, Montseny, the arrow points to the tip of the posterior apophysis incurvated towards the prolateral side; (T) D. undecima, sp. nov., Spain, Montseny.

\section{Etymology}

Named for the country in which the type locality of this species is found. Cechia (in English, Czechia) is of female gender, hence the suffix '-ica'.

\section{Material examined}

See Supplementary material file.

\section{Diagnosis}

Dysdera corallina is, together with $D$. catalonica, the largest species of the complex. It is characterised by a reddish brown carapace (Fig. $3 B$ ), long setae on the clypeus (Fig. 2D, arrow), by the shape of the copulatory organs, particulary the bulb with its very large membranous patch (Fig. $5 B$, arrow), and a vulva with a medial groove with sclerotised spicules (Figs 12B, T, arrows). As in $D$. catalonica, the bulb possesses a distal projection that forms a characteristic lobe in its apical part (Fig. 7B, arrow), visible in frontal view (Figs 9B, 11B, arrows). Unlike in $D$. catalonica, this lobe is regularly bent down in $D$. corallina (Figs 9B, 11B; C. catalonica: Figs 9A, 11A, arrows).

\section{Intraspecific variation}

Carapace length 3.3-4.4 mm; three of four spines on the ventral side of the leg IV tibia; bulb length $1.48-1.50 \mathrm{~mm}$.

\section{Remarks}

The original description of $D$. corallina is brief and the type material (unspecified number of syntypes of unspecified sex) 

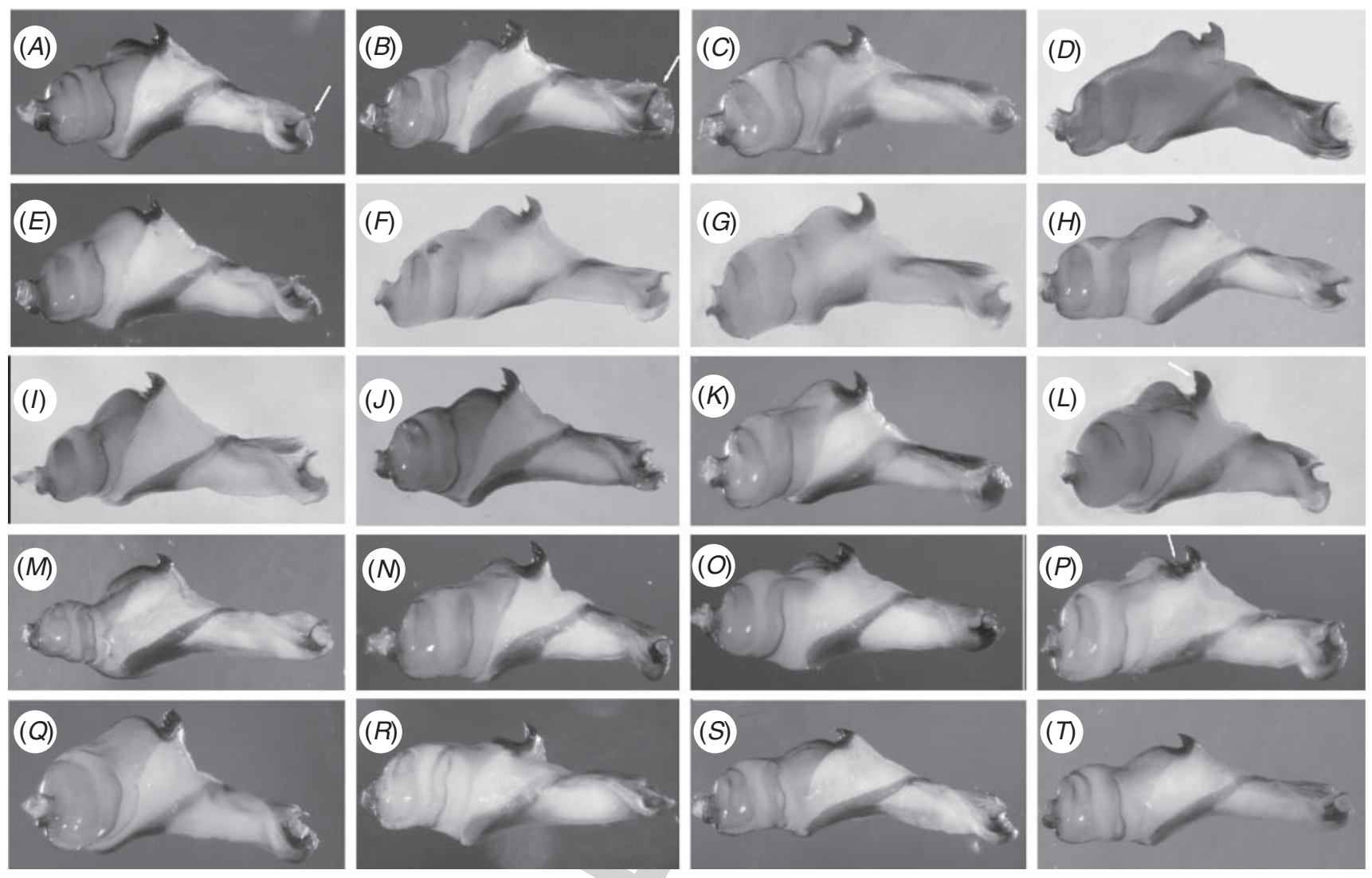

Fig. 11. Lateral view to the posterior apophysis of the left male bulb (light microscopy). (A) Dysdera catalonica, sp. nov., Spain, Montseny, the arrow points to the characteristic lobe; $(B) D$. corallina Risso, 1826, France, Provence, the arrow points to the lobe formed by the distal projection; $(C) D$. cechica, sp. nov., Czechia, Drslavice; $(D) D$. dolanskyi, sp. nov., Spain, Montblanc; $(E)$ D. erythrina (Walckenaer, 1802), Czechia, Prague; $(F) D$. fabrorum, sp. nov., Spain, Setcases; $(G)$ D. fervida Simon, 1882, France, Corsica, Rogliano; $(H)$ D. garrafensis, sp. nov., Spain, Garraf; (I) D. graia, sp. nov., France, Hérault, Clauzels; $(J) D$. kropfi, sp. nov., Switzerland, Liesberg; $(K)$ D. lantosquensis Simon, 1882, Italy, Genova; $(L) D$. minairo, sp. nov., Spain, Planes de Son, the arrow points to the proximal side of the posterior apophysis without an additional tooth; $(M) D$. portsensis, sp. nov., Spain, Ports de Beseit; $(N) D$. pradesensis, sp. nov., Spain, Montserrat; $(O)$ D. pyrenaica, sp. nov., Spain, Pyrenees, Riu de Cerdanya; $(P) D$. quindecima, sp. nov., Spain, Montseny, the arrow points to the pronounced tooth on the proximal side of the posterior apophysis; $(Q) D$. septima, sp. nov., Spain, Montseny; $(R) D$. stahlavskyi, sp. nov., France, Agay; $(S) D$. tredecima, sp. nov., Spain, Montseny; (T) D. undecima, sp. nov., Spain, Montseny.

has probably been lost, as it could not be found in the MNHN. Two species of the complex occur in the surroundings of Nice, the type locality of $D$. corallina. According to the original description, D. corallina should

5 have red chelicerae, which fit better with this species than the second, $D$. erythrina. The likely junior synonym of $D$. corallina is $D$. erythrina provincialis, a taxon originally described by Simon (1882) as D. provincialis and later degraded by the same author to subspecific level (Simon 1914). The original

10 description of $D$. erythrina provincialis does not include drawings. The type specimens of this species (unspecified number of syntypes of both sexes) were not found in Simon's collection at the MNHN; they were probably later mixed with other material. We found specimens of this species among other 15 species of the complex in a vial labelled ' $D$. erythrina, France'. However, hints to its identity can be found in the original verbal description (Simon 1882) and subsequent diagnosis published in the monograph 'Spiders of France' (Simon 1914): large body size and brown-red prosoma. Since its initial description, D. erythrina 20 provincialis has been neglected.

\section{Habitat}

Various Mediterranean forests and bushes (Quercus, Pinus, Fagus, Corylus).

\section{Distribution}

Dysdera corallina is known from the north-eastern Iberian Peninsula, southern France (revised material) and the Apennines in Italy (Simon 1914) (Fig. 13).

Dysdera dolanskyi Řezáč, sp. nov.

(Figs $3 D, 5 D, 6 D, 8 D, 9 D, 10 D, 11 D, 12 K, 13,14,15 Q, 16 I-O$ )

http://zoobank.org/urn:lsid:zoobank.org:act:C6C5DA60-EDCA-4F1AB945-7FD437948F28

\section{Material examined}

Holotype. $\hat{\jmath}$, Spain: Catalonia: Tarragona: Serra de Prades, Montblanc, $41.37^{\circ} \mathrm{N}, 1.15^{\circ} \mathrm{E}$, xerothermic Quercus forest, 3.ix.2006 [matured in January 2007], M. Řezáč and J. Dolanský (NMPC). 
(A)
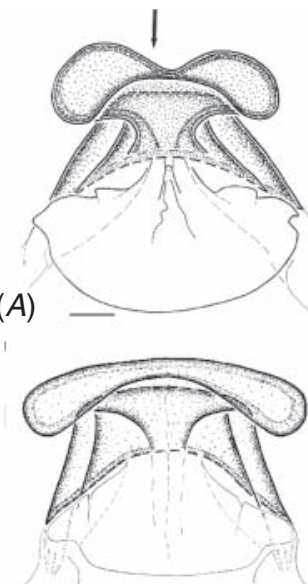

$(F)$
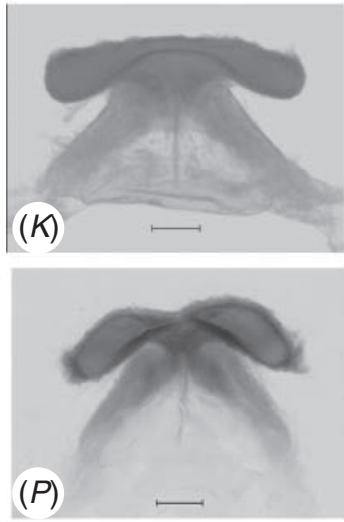

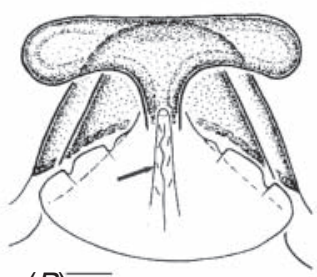

(B)

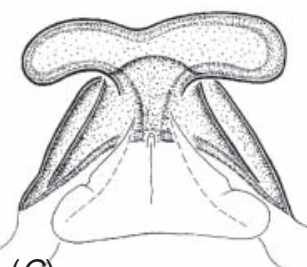

(G)
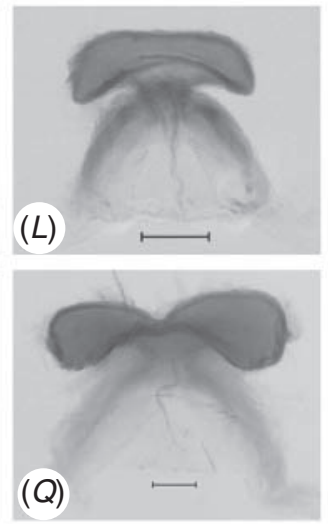

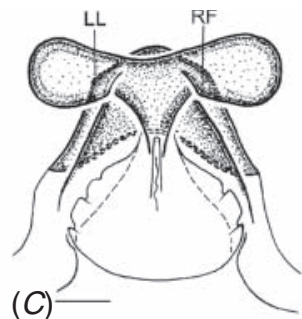

(D)
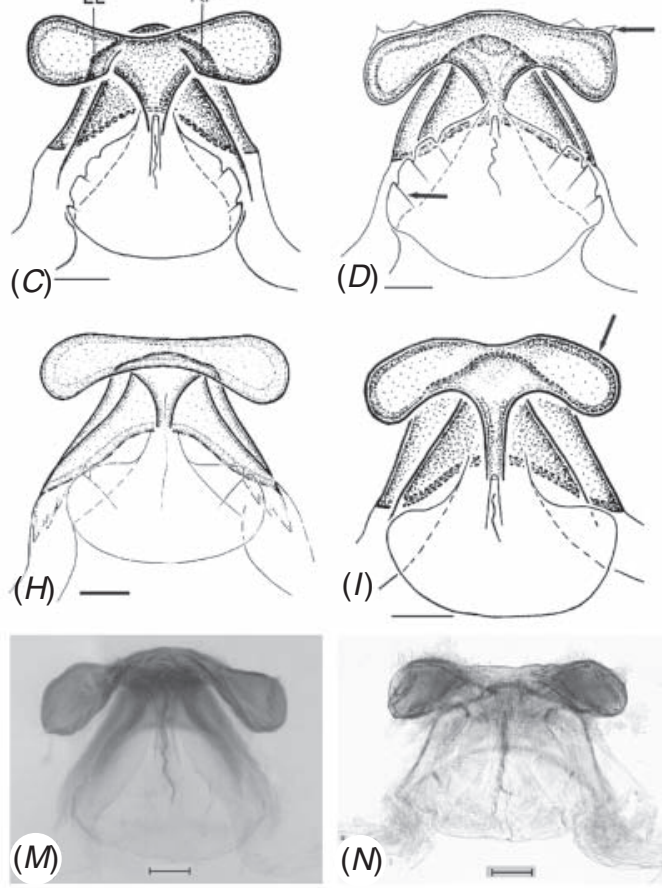

$(J)$
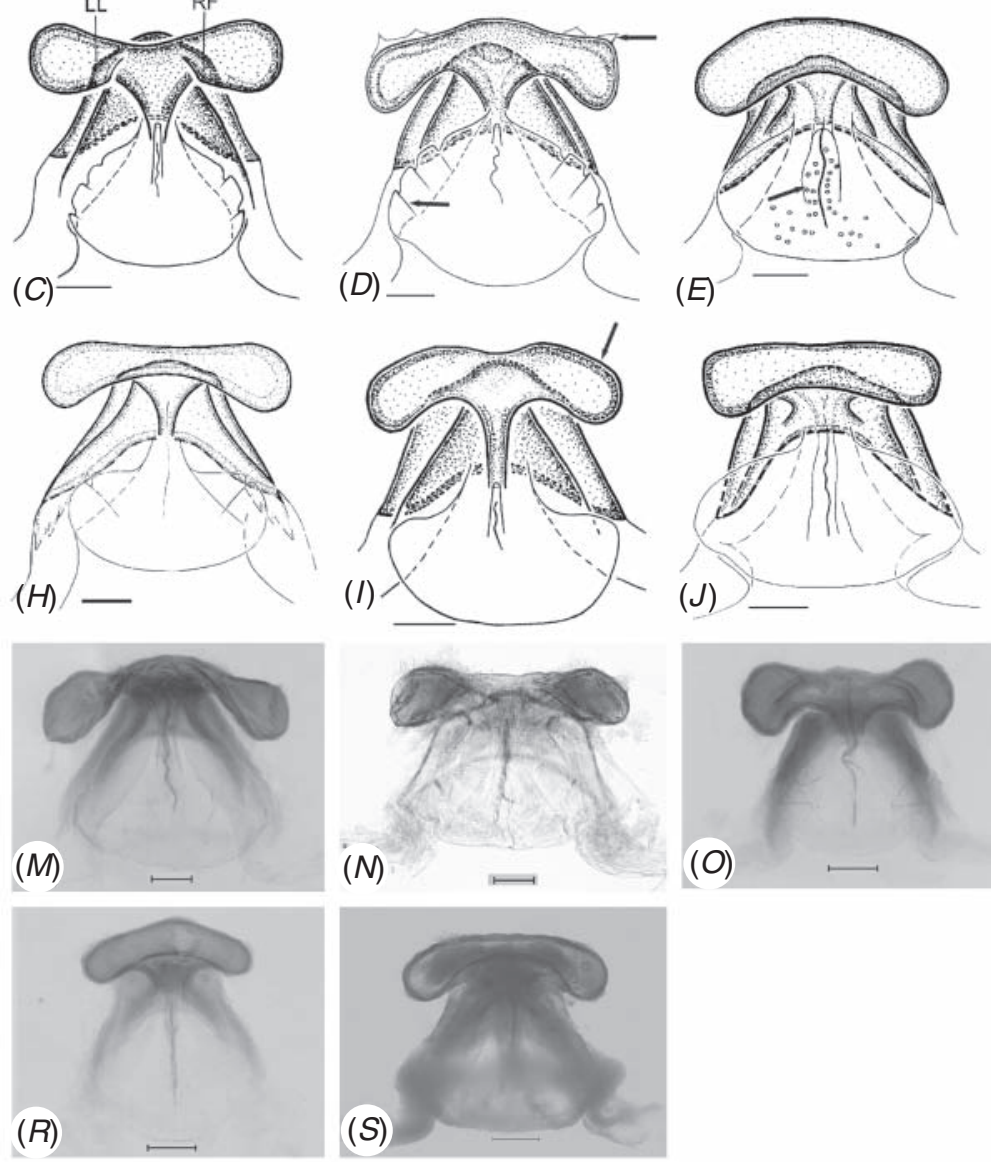
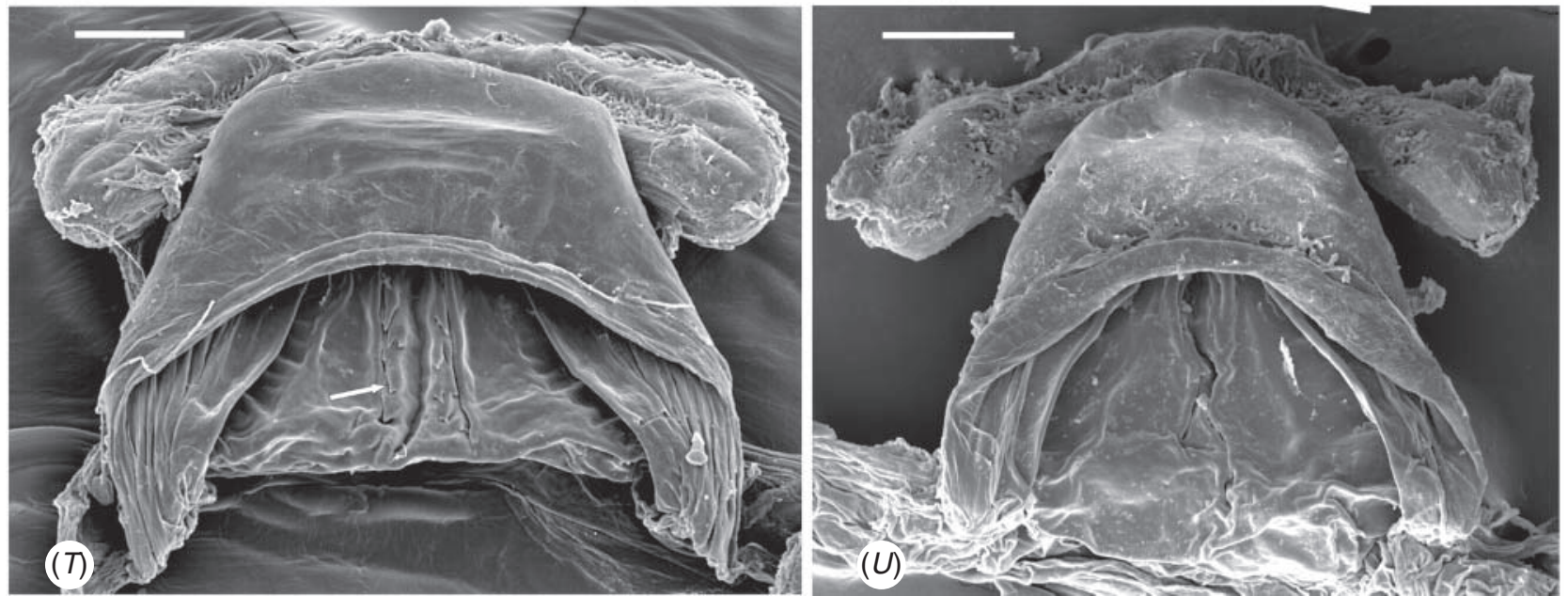

Fig. 12. Vulvae: $(A-J)$ drawings, ventral view; $(K-S)$ light microscopy, ventral view; $(T, U)$ SEM, dorsal view. $(A) D y s d e r a$ catalonica, sp. nov., Spain, Montseny, Cardedeu, the arrow points to the concave anterior margin of the spermatheca; $(B) D$. corallina Risso, 1826 , France, Provence, the arrow points to the sclerotised spicules in the medial groove; $(C) D$. cechica, sp. nov., Slovakia, Hrušov; LL, lateral lobe; RF, retroventral fold; $(D) D$. erythrina $($ Walckenaer, 1802), Czechia, Prague, the arrow points to the sclerotised teeth on the spermatheca; $(E) D$. garrafensis, sp. nov., Spain, Garraf, the arrow points to the wide medial groove with sclerotised pupiles; $(F)$ D. portsensis, sp. nov., Spain, Ports de Beseit, Cova del Vidre; $(G) D$. pradesensis, sp. nov., Spain, Serra de Prades; $(H)$ D. pyrenaica, sp. nov., Spain, Cadí-Moixeró, Riu de Cerdanya; $(I)$ D. stahlavskyi, sp. nov., France, Agay, the arrow points to the lateral edges of the spermatheca, which are incurvated backwards; $(J) D$. undecima, sp. nov., Spain, Montseny, Turó de 1'Home Mt.; (K) D. dolanskyi, sp. nov., Spain, Montblanc; $(L)$ D. fervida Simon, 1882, France, Corsica, Rogliano; $(M)$ D. graia, sp. nov., France, Salins of Clauzels; $(N)$ D. kropfi, sp. nov., Switzerland, Liesberg; (O) D. lantosquensis Simon, 1882, Italy, Genova; $(P)$ D. minairo, sp. nov., Spain, Planes de Son; $(Q) D$. quindecima, sp. nov., Spain, Montseny, Turó de l'Home Mt.; $(R)$ D. tredecima, sp. nov., Spain, Montseny, Sot del Bernadal; $(S)$ D. undecima, sp. nov., Spain, Montseny, Turó de 1'Home Mt.; (T) D. corallina, France, Provence; $(U)$ D. erythrina, Czechia, Prague. Scale bar $=0.1 \mathrm{~mm}$. 


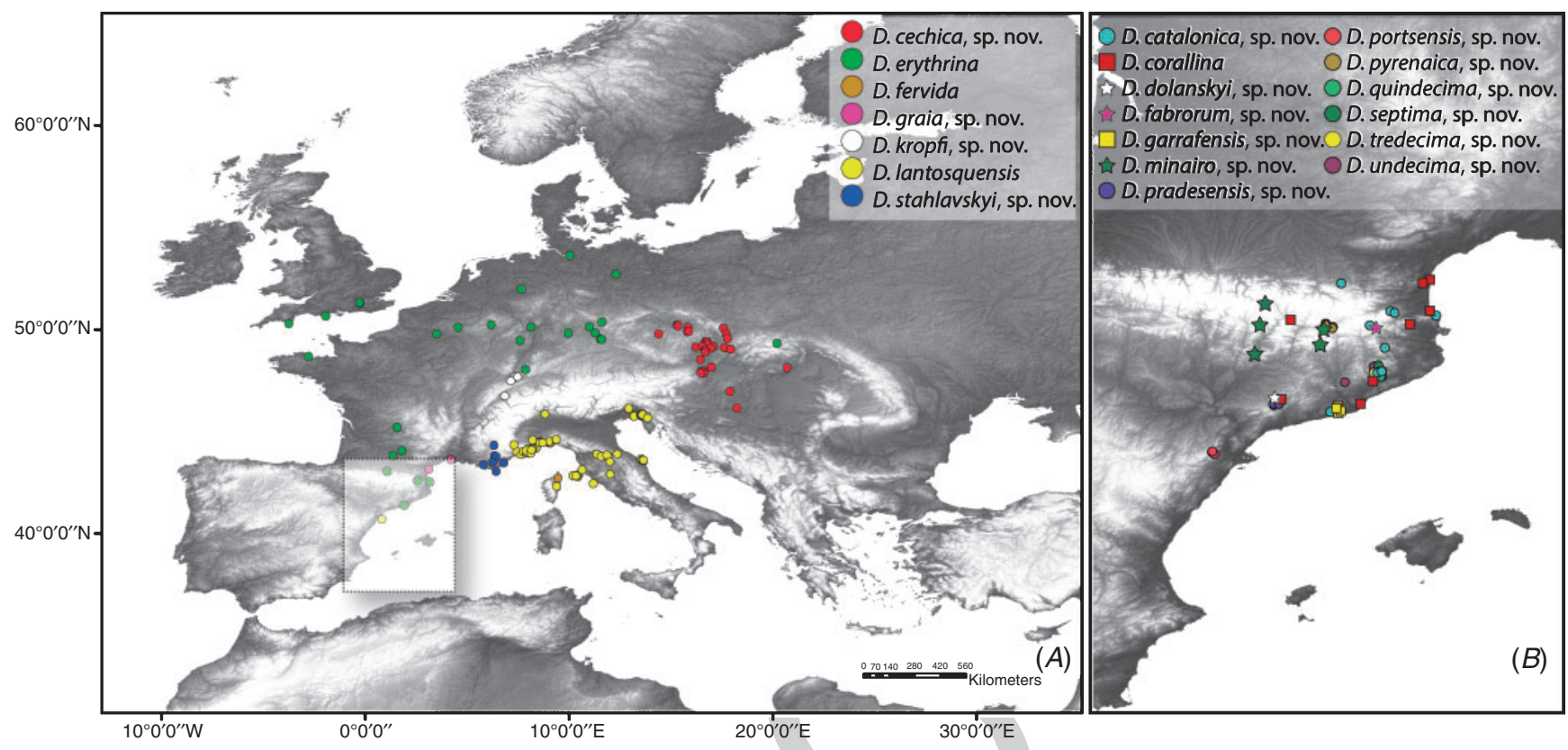

Fig. 13. Distribution of the species of the Dysdera erythrina-complex. (A) Distribution of the species found outside the Iberian Peninsula (box delineates area magnified in Fig. 13B); (B) distribution of species on the Iberian Peninsula.

Paratype. Spain: Catalonia: Tarragona: Serra de Prades, Montblanc, $41.37^{\circ} \mathrm{N}, 1.15^{\circ} \mathrm{E}$, xerothermic Quercus forest, 1 q , 3.ix.2006, M. Rezáć (MR). Other material. See Supplementary material file.

\section{Diagnosis}

5 Concerning the shape of the copulatory organs, D. dolanskyi is most similar to $D$. erythrina and $D$. fabrorum. The posterior apophysis of $D$. dolanskyi is more obtuse than in D. fabrorum and smaller than in $D$. erythrina (Figs $10 D, 11 D ; D$. fabrorum: Fig. $10 F$; D. erythrina: Fig. 10E). In contrast to D. erythrina,

10 the margins of the tegulum and distal division, opposite the posterior apophysis, are remarkably broken in the middle of the distal division (Figs $5 D, 6 D ; D$. erythrina: Figs $5 E, 6 E$ ). In contrast to D. fabrorum, the proximal part of the arch-like ridge gradually protrudes from the outline of the bulb when viewed

15 from behind (hind view) (Fig. 8D; D. fabrorum: Fig. $8 F$ ), and the membranous patch in the apical part of arch-like ridge is relatively large (Fig. 5D; D. fabrorum: Fig. $5 F$ ). The female copulatory organ of $D$. dolanskyi differs from that of $D$. erythrina in the absence of sclerotised teeth on the lateral anterior tips

20 of the spermatheca, and by the almost straight anterior margin of the dorsal arch (Fig. 12K) (in D. erythrina it is regularly round; Fig. 12D). The holotype possesses a dorsal spine on the left femur of the fourth leg; femoral spines are unique in the D. erythrina-complex. However, because of the irregular 25 presence of femoral spines in other Dysdera species, we think that their presence in the D. dolanskyi holotype could be merely an intraspecific anomaly.

\section{Intraspecific variation}

Carapace length 3.1-3.9 mm, spines on ventral side of fourth leg

\section{Remarks}

This species is not well defined by morphological or molecular markers. However, it can be clearly distinguished from the other species of the complex by a derived karyotype that includes a unique $\mathrm{X}_{1} \mathrm{X}_{2} 0$ sex-determination system. The karyotypes in all examined cells were identical, making the possibility of erroneous interpretation of our observation impossible. The evolution of the $D$. dolanskyi karyotype must have involved more chromosomal changes (Table S4). Despite this fact, we found entirely regular segregation of chromosomes in male meiosis - only standard gametes with a complete genome are produced. Therefore, we exclude the possibility that the karyotyped individual has an aberrant karyotype.

\section{Habitat}

Dysdera dolanskyi was found in the forest fringe, at around $410 \mathrm{~m}$ elevation.

\section{Distribution}

This species has only been found in the area surrounding Tarragona, Catalonia (north-eastern part of the Iberian Peninsula (Fig. 13)).

\section{Etymology}

Named after the Czech arachnologist Jan Dolanský, our colleague who helped to discover this species.

\section{Dysdera erythrina (Walckenaer)}

(Figs $1,2 B, F, 3 E, 4 C, D, 5 E, 6 E, 7 D, 8 E, 9 E, 10 E, 11 E, 12 D$,

$$
U, 13,14,15 O, 16 H \text { ) }
$$

Aranea erythrina Walckenaer, 1802: 224. Type locality: France, surroundings of Paris. The type material has been lost. 


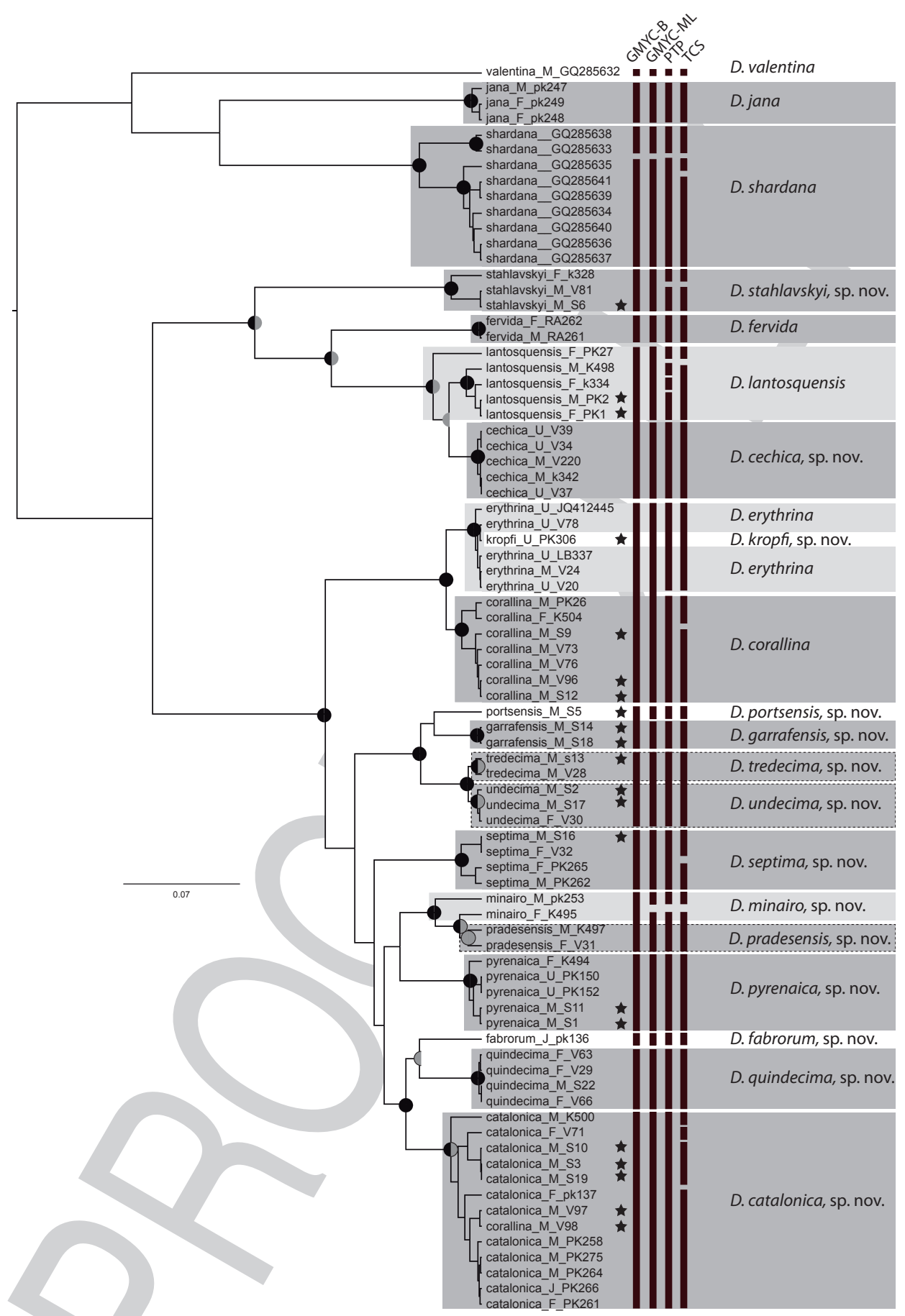

Fig. 14. Bayesian consensus tree inferred with BEAST using the parameter values specified in the text. Circles on nodes denote clade support as follows: the left semicircle corresponds to Bayesian posterior probability (PP) and the right semicircle to maximum likelihood (ML) bootstrap; black semicircles indicate clades supported by PP $>0.95$ and ML bootstrap $>80 \%$; grey semicircles are clades supported below the former values; white dots indicate clades not recovered in this particular analysis; grey boxes delimit nominal species; dark grey boxes indicate species recovered as monophyletic; light grey boxes are paraphyletic species; species with a single representative were not boxed. Bars on the right columns correspond to the clusters inferred under alternative delimitation methods: groups recovered by the general mixed Yule-coalescent (GMYC) model, based either on the Bayesian ultrametric tree (GMYC-B) or the Pd8 transformed ML tree (GMYC-ML), groups delimited by the Poisson tree processes (PTP) method or groups corresponding to independent Templeton-Crandall-Sing (TCS) allele networks. Individuals analysed both by molecular and cytogenetic methods are marked by stars. 
(4) 35753<smiles>[2H]</smiles>

(B)

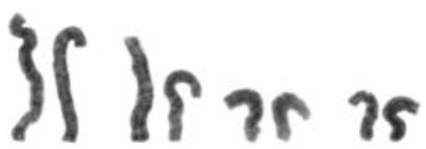

9

(C) $\mathrm{O}$ If 16 is

$\checkmark$

(D) $7 \mathrm{f} 7 \mathrm{r}$ ir ir

(E) SC II if II

)

( $)$ In If Ie 18 If

1

(G) ?C le is $ו$ in

3

(H)

1)

(I) 36 be ge ic se It

2

(J) $7 \mathrm{e}$ 3e is is is is

$\xi$

(K) If It le le or of il

2

(L) TF TS TS Do To is ie

3

(M) le if is is 15 is at

7

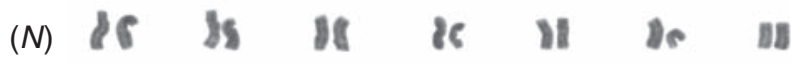

\}

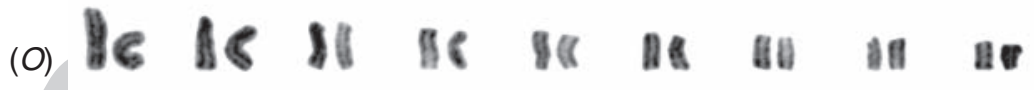

?

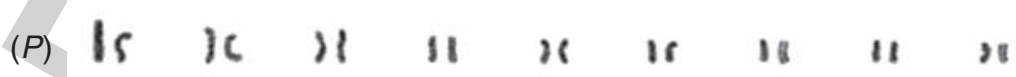

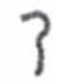

(Q)

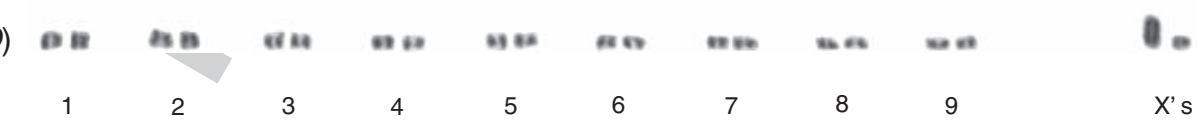

Fig. 15. Male karyotypes, unless otherwise indicated, based on spermatogonial metaphase. (A) Dysdera septima, sp. nov.; (B) D. catalonica, sp. nov.; (C) D. stahlavskyi, sp. nov.; (D) D. pyrenaica, sp. nov.; (E) D. cechica, sp. nov.; $(F) D$. undecima, sp. nov.; $(G) D$. pradesensis, sp. nov.; $(H) D$. minairo, sp. nov.; (I) D. lantosquensis Simon, $1882 ;(J) D$. tredecima, sp. nov.; $(K) D$. garrafensis, sp. nov.; $(L) D$. portsensis, sp. nov.; $(M) D$. quindecima, sp. nov.; $(N) D$. kropfi, sp. nov.; $(O) D$. erythrina (Walckenaer, 1802); $(P) D$. corallina Risso, 1826; $(Q) D$. dolanskyi, sp. nov. (anaphase I). Scale bar $=10 \mu \mathrm{m}$. 

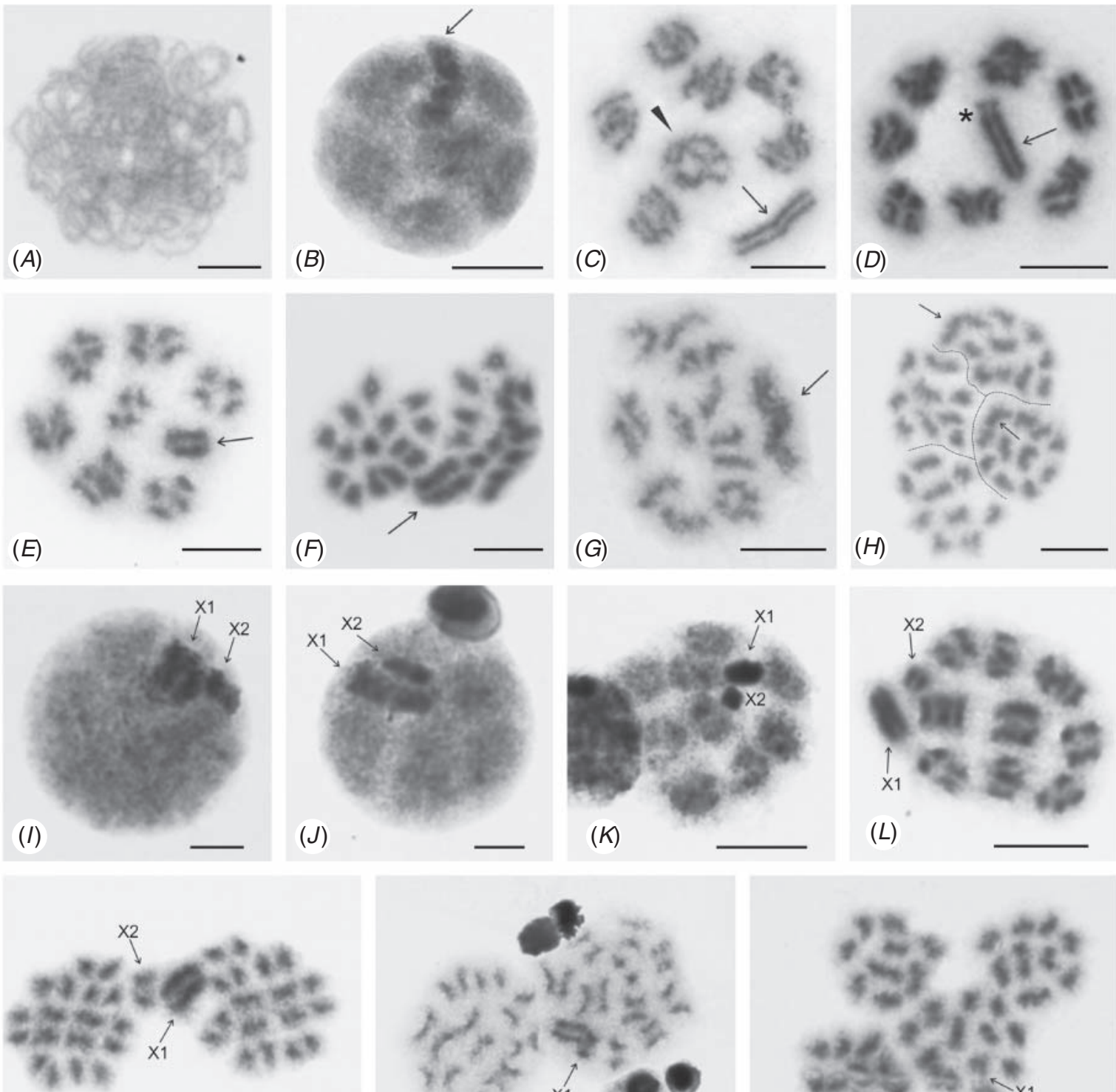

$(M)$
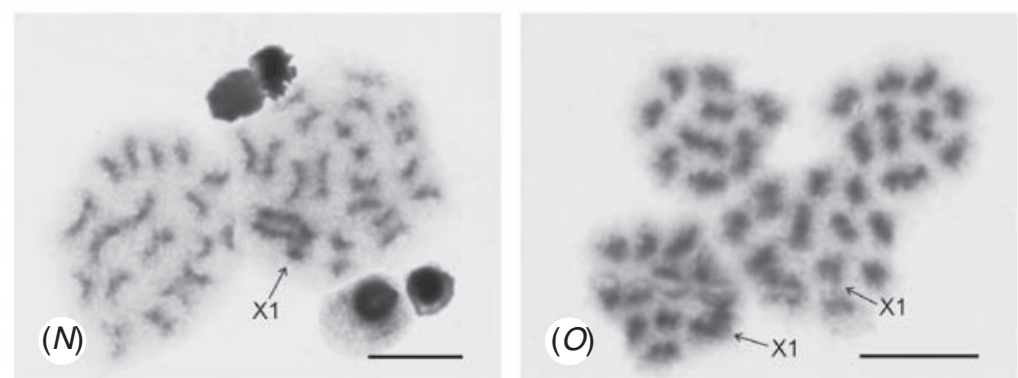

Fig. 16. Male meiosis of the Dysdera erythrina-complex. The prophase of the first meiotic division in Dysdera males includes a specific period exhibiting considerable decondensation of autosome bivalents (i.e. the so-called diffuse stage). $(A-H)$ Dysdera species with X0 system. ( $B, J, K)$ In contrast to autosomes, the $\mathrm{X}$ chromosome is intensively stained during diffuse stage due to overcondensation. $(E, L)$ Chiasmata of autosome bivalents are completed during late metaphase I. (A) Dysdera pyrenaica, sp. nov., zygotene - the X chromosome shows the same intensity of staining (i.e. isopycnosis) as autosomes, and therefore is unidentifiable; X chromosome (arrow) exhibits positive heteropycnosis except for zygotene; $(B) D$. garrafensis, sp. nov., diffuse stage; (C) D. garrafensis, diakinesis (arrowhead, bivalent with two chiasmata); $(D)$ $D$. garrafensis, early metaphase I (asterisk - subterminal constriction of X chromosome); (E) D. quindecima, sp. nov., late metaphase, separation of X chromosome chromatids is delayed from late metaphase I; $(F)$ D. garrafensis, anaphase I (sex chromosome consists of two chromatids and exhibits a delayed segregation); $(G)$ D. garrafensis, prometaphase II; $(H) D$. erythrina(Walckenaer, 1802), two sister anaphases II, one containing $\mathrm{X}$ chromosome. ( $I-O)$ Dysdera dolanskyi, sp. nov., $\mathrm{X}_{1} \mathrm{X}_{2} 0$ system $\left(\mathrm{X}_{1}\right.$ and $\mathrm{X}_{2}$ are the sex chromosomes). (I-M) Note an association of $\mathrm{X}$ chromosomes. The $\mathrm{X}_{1}$ chromosome is positively heteropycnotic at premeiotic interphase $\mathrm{I}$ and from diffuse stage to metaphase II. $(I-K)$ By contrast, heteropycnosis of the $\mathrm{X}_{2}$ chromosome is restricted to interphase and diffuse stage; during metaphase $\mathrm{I}, \mathrm{X}_{1}$ chromosome exhibits only slight positive heteropycnosis; separation of $\mathrm{X}_{1}$ chromatids is delayed from metaphase I to metaphase II. (I) Premeiotic interphase; $(J)$ early diffuse stage; sex chromosomes are arranged in parallel; $\mathrm{X}_{2}$ chromosome is composed of two parts differing by intensity of heteropycnosis; left segment of this chromosome is stained less intensively than right one; $(K)$ late diffuse stage; $(L)$ metaphase I; $(M)$ anaphase I (sex chromosomes comprise two chromatids and exhibit a delayed segregation); $(N)$ metaphase II consisting of two sister plates, one containing 11 chromosomes including two $\mathrm{X}$ chromosomes, the other one containing nine chromosomes (note the constriction in the right part of $\mathrm{X}_{1}$ chromosome); $(O)$ two sister anaphase II, one containing X chromosomes. Scale bar $=10 \mu \mathrm{m}$ except for $I$ and $J(5 \mu \mathrm{m})$. 
Dysdera erythrina: Blackwall, 1864: 370, pl. 28, fig. 266 ( (3우); Becker,

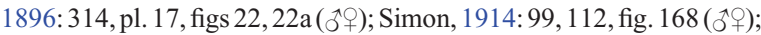
Roewer, 1928: 50, pl. 7, fig. 562 (ঐ)); Locket \& Millidge, 1951: 84, fig. 42A, D (3)); Wiehle, 1953: 16, figs 36-43 (3ㅇ); Charitonov, 1956: 26 , fig. 18 (ङ); Alicata, 1964: 6, fig. 4 (†); Cooke, 1966: fig. 3 (†); Muller,

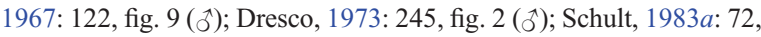

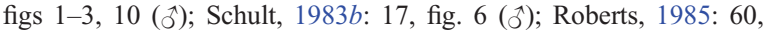
fig. 19a, c, e, g ( $\left.\hat{\sigma}^{\circ}\right)$; Deeleman-Reinhold \& Deeleman, 1988: 164, figs 8, 50 (ํํ); Heimer \& Nentwig, 1991: 44, figs 95.4-95.6 ()); Roberts,

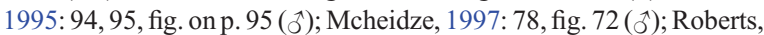

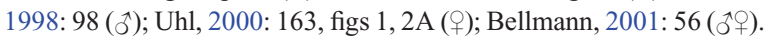
Dysdera cambridgii Thorell, 1873: 465. Type localities: Germany: Bad Pyrmont, Kissingen; Great Britain: England. Synonymised by Simon (1914): 113. Dysdera cambridgii Thorell: Chyzer \& Kulczyński, 1897 : 268, pl. 10, figs 40, 45 (ぷ+o).

Dysdera rubicunda C. L. Koch, 1838: 79, fig. 390a, b (ô) (misidentification).

\section{Material examined}

Lectotype of Dysdera cambridgii (present designation, originally undifferentiated syntypes). Germany: Kissingen: 0 , T. Thorell (NHRS: 95/147b) (used here for redescription of D. erythrina).

Paralectotypes of Dysdera cambridgii. Germany: Kissingen: $1 \hat{\jmath}, 1$, 7 juv., T. Thorell (NHRS: 95/147b); Bad Pyrmont: 4, 1 juv., 24 ix, year unspecified, T. Thorell (NHRS: 95/147a). Great Britain: England: 1 s,

Other material. See Supplementary material file.

\section{Diagnosis}

Dysdera erythrina differs from the other species of the complex by: the whole sternum having setae, even in older individuals; the

30 shape of copulatory organs, especially the male bulb, which has an almost apically positioned (Fig. 6E), straight (Fig. 11E), triangle-shaped (Fig. 10E) posterior apophysis with a tooth on its proximal side (Fig. 9E); and the anterior sides of the lateral tips of the spermatheca having conspicuous sclerotised teeth-like w; 12U) chromosome number with $D$. corallina, from which it clearly differs in the much smaller membranous patch in the apical part of bulb (Fig. 5E, D. corallina: Fig. $5 B$ ) and the absence of sclerotised spicules in the medial groove of the vulva

40 (Fig. $12 D, U ; D$. corallina: Fig. $12 B, T$ ).

\section{Intraspecific variation}

Carapace 2.6-4.0 mm long, 3-5 spines on the ventral side of the leg IV tibia, bulb 1.1-1.6 mm long. The material from southern France and the north-eastern Iberian Peninsula shows remarkable the posterior apophysis. Samples of these aberrant populations were not available for karyological or DNA analyses. This variation may reflect further, thus far uncovered species diversity.

\section{Remarks}

50 The type material of D. erythrina (unspecified number of syntypes of unspecified sex) has probably been lost, as it could not be found in the MNHN. However, the identity of $D$. erythrina is clear, as the type material was collected from the area surrounding Paris, which is a region where only one species 55 from the $D$. erythrina species-complex occurs. The name $D$. cambridgii is the junior synonym of $D$. erythrina, as the examined type material of $D$. cambridgii (the syntypes come from Germany and Great Britain) is identical to D. erythrina. We chose the syntype from Germany for the lectotype.

Several references of $D$. erythrina are considered doubtful. The bulbs illustrated in Dufour (1820: 38, pl. 73, fig. 7, 今̂) and Koch (1838: 76, fig. 389, ô) do not seem to belong to any species of the $D$. erythrina species-complex. However, their schematic drawings, as well as drawings in Hahn (1831: 7, pl. 1, fig. 3, o ) and Fage (1913: 499, figs 3-6, unspecified sex), which can be attributed to $D$. erythrina-complex, do not allow for more accurate identification. The female body illustrated by Audouin (1826: 380, pl. 5, fig. 3) was from the Middle East, where the $D$. erythrina-complex does not occur. The drawing in Drensky (1938: 93, fig. 8e, ô) was perhaps redrawn after Chyzer and Kulczyński (1897) and Simon (1914). In this case, however, the shape of the bulb rather resembles that of $D$. cechica. The bulb illustrated under the name $D$. cambridgei [sic] in Bösenberg (1902: 320, pl. 30, fig. 473c) resembles $D$. corallina in shape. However, D. corallina probably does not occur in Germany. The drawings in Charitonov (1956) and Mcheidze (1997) were redrawn after Chyzer and Kulczyński (1897). The drawing in Dresco (1973) was adapted from Simon (1914).

The male of $D$. erythrina was probably described by C.L. Koch in 1838 as Dysdera rubicunda. The depicted bulb is inflexed, resembling rather D. cechica. However, the Dysdera rubicunda type material came from Germany and the western part of Czechia, where only D. erythrina occurs. Therefore, the author most probably worked with $D$. erythrina, with any resemblance to $D$. cechica caused by inaccuracy in the figure. We failed to find the type material in the collections listed at the end of 'Materials and methods'. Koch coupled males of D. erythrina with females belonging to the genus Harpactea (the species nowadays bearing the name $H$. rubicunda). In the introduction of the description, he emphasised the eye arrangement, which is present in Harpactea, but not in Dysdera. Thus, the female was probably more important to the author in establishing the new species. In order to stabilise the nomenclature, the species name rubicunda should be henceforth used for this common central European species of Harpactea. Thaler and Knoflach (2002) also noted this confusion.

\section{Habitat}

In Czechia, this species occurs in xerothermic forests on slopes (e.g. in plant communities of Carpinion, Quercion pubescentipetraeae, Quercion petraeae, Genisto germanicae-Quercion and, less often, Fagion) and their fringes (Geranion sanguinei), in bushes (Berberidion) and in shaded parts of dry grasslands and heaths (Festucion valesiacae, Bromion erecti, Euphorbio-Callunion). It is also common in planted forests and semi-rural woods and bushes (often with Hedera helix on the ground), especially in areas surrounding ruins. Its occurrence is mainly concentrated in habitats enriched by calcium carbonate, which is essential for the proliferation of woodlice (Řezáč et al. 2007).

\section{Natural history}

According to observations of Czech populations, mating likely takes place between April and June, with eggs laid in June and 
July. Spiderlings disperse from the maternal retreat in August and September. Most mature in the September of the following year, overwinter as adults and mate the next spring. Thus, this species has a biennal life cycle.

\section{Distribution}

Dysdera erythrina has probably the largest distribution of all species of this complex, stretching from the Iberian Peninsula to the western parts of Czechia (see map in Řezác 2012) and Austria. It reaches as far north as England, Belgium, Netherlands, northern

10 Germany and Poland (Fig. 13). The species is probably able to disperse outside its natural distribution using means of human transportation across semi-rural habitats. Such introduction is documented by material from Slovakia and Mauritius (although in the latter case, mislabelling should also be taken into

15 consideration). The record of this species from the Middle East (Audouin 1826) is probably a misidentification.

The maps for Germany (Staudt 2015) and Great Britain (British Arachnological Society 2015) are probably based solely on material of $D$. erythrina. The distribution map of

20 D. erythrina for Slovakia (Gajdoš et al. 1999) is based on the material of D. cechica; the map for Czechia (Buchar and Rưžička 2002) combines both $D$. erythrina and D. cechica, and the map for Serbia (Deltshev et al. 2003) is likely based on material of D. cechica. The distribution maps for Spain (Romano and

25 Ferrández 1983; Ribera et al. 1986) may depict any species of the $D$. erythrina-complex.

Dysdera fabrorum Řezáč, sp. nov.

(Figs $3 F, 5 F, 6 F, 8 F, 9 F, 10 F, 11 F, 13,14$ )

http://zoobank.org/urn:lsid:zoobank.org:act:940E304F-1BD5-42118B08-40DFB0F42D24

\section{Material examined}

Holotype. $\hat{\jmath}$, Spain: Catalonia: Girona: Setcases, $42.391^{\circ} \mathrm{N}, 2.295^{\circ} \mathrm{E}$, humid Fagus forest near stream, 20.x.2004, M.A. Arnedo and E. De Mas (CRBA 000811).

Other material. See Supplementary material file.

\section{Diagnosis}

It is similar to D. quindecima, D. pyrenaica, D. septima and D. minairo. In males of these species, the margin of the tegulum and distal division, opposite the posterior apophysis, are almost in

40 line when viewed retrolaterally (Fig. 5F; D. quindecima: Fig. 5P; D. pyrenaica: Fig. 5O; D. septima: Fig. 5Q;D. minairo: Fig. $5 L$ ). However, the posterior apophysis in $D$. fabrorum is relatively small and pointed (Figs $10 F, 11 F ; D$. quindecima: Figs $10 P, 11 P$; D. pyrenaica: Figs $10 O, 11 O$; D. septima: Figs 10Q, 11Q;

45 D. minairo: Figs $10 \mathrm{~L}, 11 \mathrm{~L}$ ). Unlike in other species of the complex, the proximal side of the posterior apophysis of D. fabrorum bears a bifurcate additional tooth (Fig. 10F, arrow).

\section{Habitat}

High elevation (>1200 m) beech forest, in a narrow valley near a

\section{Distribution}

Known from a single locality in the Girona Pyrenees, Catalonia (Spain) (Fig. 13).

\section{Etymology}

'Fabrorum' is a genitive plural of 'faber', the Latin word for 5 forger or smith. The name of this spider thus means Dysdera of the forgers. The region where the species comes from was famous in the Middle Ages for its forgers, who produced some of the finest European iron and steel.

\section{Dysdera fervida Simon}

$$
\text { (Figs } 3 G, 5 G, 6 G, 8 G, 9 G, 10 G, 11 G, 12 L, 13,14 \text { ) }
$$

Dysdera fervida Simon, 1882: 216. Type localities: France, Corsica and Provence.

Dysdera erythrina fervida: Simon, 1914: 99, 113 (ぷ).

\section{Material examined}

Lectotype. Dysdera fervida (present designation, originally undifferentiated syntypes), $1 \hat{\jmath}$, France: Corsica (coll. E. Simon in MNHN AR5952).

Paralectotype. 1 क, France: Corsica (coll. E. Simon in MNHN AR5952).

Other material. See Supplementary material file.

\section{Diagnosis}

Dysdera fervida is one of the smallest species of the complex. It differs from the other species by the shape of the copulatory organs. It is most similar to D. cechica and even more to D. lantosquensis. It differs from them by having a bulb with a higher and wider lump and a larger arch-like ridge. Furthermore, the margin of the tegulum and distal division opposite the posterior apophysis in retrolateral view is almost in line (Fig. $5 G$; D. cechica: Fig. $5 C$; D. lantosquensis: $5 K$ ). In contrast to $D$. cechica, the distal half of the tegulum is wider than the proximal half. In contrast to D. stahlavskyi, which was considered conspecific by Simon (1882), the distal projection of the bulb of $D$. fervida does not form a lobe in its proximal part and does not protrude forwards from the distal part of the bulb. The vulva of $D$. fervida is characterised by a narrow spermatheca with a straight anterior margin (Fig. 12L). In contrast to D. stahlavskyi, the anterior margin of the dorsal arch lacks shoulders (D. stahlavskyi: Fig. 12I). Moreover, D. fervida differs from most other species (except for D. cechica, D. lantosquensis, D. garrafensis, D. portsensis and $D$. stahlavskyi) by relatively long (almost $0.1 \mathrm{~mm}$ ) setae on the dorsal side of the opisthosoma.

\section{Intraspecific variation}

Carapace length 2.1-2.3 mm, two or three spines on the ventral 45 side of the leg IV tibia.

\section{Remarks}

The original description of $D$. fervida does not include any drawings. However, the written description (Simon 1882) and diagnosis (Simon 1914) provide some diagnostic characteristics: small body size, brown-ferruginous prosoma, only three spines on 
the ventral side of leg IV tibia. The species has not been reported since its orginal description. We examined two syntypes $(1 \hat{\jmath}, 1+)$ from Corsica, which allows us to confirm its validity. Although we were not able to trace the syntypes from Provence in Simon's 5 collection in the MNHN, we found that specimens matching Simon's original description were mixed with other species of the complex in a vial labelled ' $D$. erythrina, France' stored at the MNHN. It is probable that Simon himself mixed the specimens he used to describe the orginal species proposed in

101882 and that were later sunk into D. erythrina (Simon 1914). After careful examination, we concluded that the Corsican specimens and the continental ones were not conspecific, and the later are here described as D. stahlavskyi. To fix the identity of the species, we designate a male syntype from Corsica as a 15 lectotype. However, the redescription of $D$. fervida here is based on the male from Rogliano, Cape Corse, from which we successfully isolated the DNA.

Thorell (1873: 580) described Dysdera pumila Thorell, 1873 based on a male collected by F. Söderlund from Formentera 20 (Balearic Islands, Spain). Unfortunatelly, the original description of $D$. pumila lacks drawings and we were not able to examine the type specimen, which is probably lost, as it is missing in Thorell's collection in the NHRS (T. Kronestedt, pers. comm.). The World Spider Catalog (2016) lists D. pumila as a junior 5 synonym of $D$. erythrina. This synonymy is probably based on misinterpretation of Simon's suggestion of synonymy with D. erythrina fervida (Simon 1914: 113). He marked the synonymisation with a question mark, which could mean that he did not see the type and speculated on the synonymy because of

30 the small body size and close type localities. Thorell obviously knew D. erythrina well (he considered it a new species, because he did not compare it with Walckenaer's material) because he described D. pumila and D. cambridgii (a junior synonym of D. erythrina) in the same paper. Further collecting of 35 Dysdera in the Balearic Islands is required to clarify the identity of $D$. pumila, which may also have an impact on the nomenclature of $D$. fervida.

\section{Habitat}

Secondary coastal Quercus ilex forest at low elevation.

\section{Distribution}

Dysdera fervida is known from Corsica (Fig. 13). Dysdera pumila, a putative synonymy of $D$. fervida, is known from the island of Formentera (Balearic Islands).

Dysdera garrafensis Řezáč, sp. nov.

(Figs $2 G, 3 H, 5 H, 6 H, 7 E, 8 H, 9 H, 10 H, 11 H, 12 E, 13,14$, $15 K, 16 B-D, F, G$

http://zoobank.org/urn:1sid:zoobank.org:act:CC3CFE45-60D5-4E259CD7-01E93AAE20EB

\section{Material examined}

Holotype. ô, Spain: Catalonia: Barcelona: Garraf Natural Park, along the road from Pleta to Begues, $41.305^{\circ} \mathrm{N}, 1.881^{\circ} \mathrm{E}$,.vi.2002, E. De Mas (CRBA VO000050).

Paratypes. Spain: Catalonia: Barcelona: Garraf Natural Park, along the road from the Monasterio Budista del Garraf to Begues, $41.305^{\circ} \mathrm{N}, 1.881^{\circ} \mathrm{E}, 2$
ऽ, 6.vi.2002, E. De Mas (CRBA VO000049-50); Garraf Natural Park, $41.290^{\circ} \mathrm{N}, 1.874^{\circ} \mathrm{E}, 1$ ㅇ, 21.vi.2002, E. De Mas (CRBA VO000051); Garraf Natural Park, Garraf, $41.270^{\circ} \mathrm{N}, 1.915^{\circ} \mathrm{E}$, Pinus and Quercus ilex forest, $41.2567^{\circ} \mathrm{N}, 1.9089^{\circ} \mathrm{E}$, humid gravel covered by moss and Juncus grass on the bottom of the valley, 5 ô, 4 \&, 4 juv., 27.iv.2009, M. Řezác (MR).

Other material. See Supplementary material file.

\section{Diagnosis}

Dysdera garrafensis is characterised by rich spination on the ventral side of the leg IV tibia (often more than four spines), relatively long legs compared with the rest of the prosoma, relatively long hairs on the dorsal side of the opisthosoma, and by the shape of the copulatory organs. The bulb is similar to those of $D$. portsensis, D. undecima and D. tredecima. Distal division of the bulb is characterised by slightly counter-clockwise rewinding around the longitudinal axis of the bulb and it is remarkably inclined in respect to the tegulum, in retrolateral view (Figs $5 \mathrm{H}$, $7 E$ ). The pointed tip of the small posterior apophysis is incurvated towards the prolateral side (Fig. 10H, arrow, incurvated upwards in the figure). The distal projection partly covers the fosette (Fig. $7 E$, arrow). The vulva is characterised by a very wide medial groove, with sclerotised pupiles inside and posteriorly also outside the groove (Fig. 12E, arrow). It differs from similar $D$. undecima and $D$. tredecima in having a more wrinkled carapace (Fig. $2 G$; D. undecima: Figs $2 K, 3 T$; D. tredecima: Fig. $3 S$ ), and from $D$. portsensis in having a red-brown carapace (Fig. $3 H$; D. portsensis: Fig. 3M).

\section{Intraspecific variation}

Carapace length 2.8-3.3 mm; 4-7 spines on ventral side of the fourth leg tibia; bulb length $1.10-1.25 \mathrm{~mm}$.

Habitat

Dysdera garrafensis was found in evergreen oak forest and pine forest (Pinus alepensis).

\section{Distribution}

Known only from the Garraf Massif on the north-eastern Iberian Peninsula (Fig. 13).

Etymology

Named after the Garraf Massif, part of the Catalan Coastal Range, where all currently known specimens were found. The suffix '-ensis' means place.

$$
\text { Dysdera graia Řezáč, sp. nov. }
$$

$$
\text { (Figs 3I, 5I, 6I, 8I, 9I, 10I, 11I, 12M, 13, 14) }
$$

\section{http://zoobank.org/urn:lsid:zoobank.org:act:5B1C8518-5480-462E- 8274-61E427AA3D70}

\section{Material examined}

Holotype. $\hat{\jmath}$, France: Languedoc-Roussillon: Hérault: Villeneuve les Maguelone: Salins de Villeneuve, Clauzels, $43.51691^{\circ} \mathrm{N}, 3.84794^{\circ} \mathrm{E}$, salt marshes, altitude $3 \mathrm{~m}$, pitfall trap, 12.ix.2011, G. Maxime (NMPC).

Paratypes. France: Languedoc-Roussillon: Gard: Gallargues le Montueux, Roc de Luche, chemin de Sommières, $43.72918^{\circ} \mathrm{N}, 4.16789^{\circ} \mathrm{E}$, altitude $30 \mathrm{~m}$, garrigue, 2 \%, 16.iii.2008, S. Danflous (coll. S. Danflous); Hérault: Villeneuve les Maguelone: Salins de Villeneuve, Clauzels, 
$43.51691^{\circ} \mathrm{N}, 3.84794^{\circ} \mathrm{E}$, salt marshes, altitude $3 \mathrm{~m}$, pitfall trap, 1 , 12.ix.2011, 1 +, 9.x.2011, G. Maxime (coll. S. Déjean); Aude: Gruissan, $43.1125^{\circ} \mathrm{N}, 3.091111^{\circ} \mathrm{E}$, salt marsh, 1 oै $^{\circ} 1$ \%, 24.iv.1980, R. Bosmans (coll. R. Bosmans); Bouches-du-Rhône: Aigues Mortes, $43.5606^{\circ} \mathrm{N}, 4.1778^{\circ} \mathrm{E}, 1$ 今, 52 \%, 16.iv.1984, P. Poot (coll. R. Bosmans).

Other material. See Supplementary material file.

\section{Diagnosis}

Dysdera graia is similar to D. erythrina, from which it differs mainly in that the distal cheliceral tooth is positioned more distally

10 (distance of distal tooth from distal end of fang furrow/length of groove ratio $<0.45$ ). The male copulatory organ is very similar to that of $D$. erythrina, from which it differs by a narrower proximal part of the tegulum relative to the rest of the bulb, and a longer distal division relative to the tegulum (Fig. 5I; D. erythrina:

15 Fig. $5 E$ ). The vulva is characterised by a spermatheca with the lateral parts markedly bent distally (Fig. 12M). In contrast to $D$. erythrina, their anterior sides are without sclerotised muscle anchors (D. erythrina: Fig. 12D).

\section{Intraspecific variation}

20 Carapace length $2.9-4.8 \mathrm{~mm} ; 3-5$ spines on the ventral side of the leg IV tibia; bulb length $1.3-1.5 \mathrm{~mm}$; position of the distal tooth (distance of distal tooth from distal end of groove/length of groove ratio) $0.20-0.40$.

\section{Habitat}

25 Salt marshes and other lowland habitats close to the sea coast.

\section{Distribution}

Coast around Montpellier in southern France (Fig. 13).

\section{Etymology}

The Graiai are three old women from Greek mythology. They

30 share a single detatchable eye and tooth and they always argue about them. This species is characteristic by its pronounced tooth on the chelicerae. In Greek, Dysdera means grumpy, this adjective describes Graia's personality well. It is to be treated as a noun in apposition.

\section{Dysdera kropfi Řezáč, sp. nov.}

(Figs 3J, 5J, 6J, 8J, 9J, 10J, 11J, 12N, 13A, 14, 15N)

http://zoobank.org/urn:lsid:zoobank.org:act:36739279-1D2F-4ACE803C-9285AFEEBC2B

\section{Material examined}

Holotype. ô, Switzerland: Baselland: Liesberg, $42.48^{\circ} \mathrm{N}, 7.75^{\circ} \mathrm{E}$, forest fringe on steep stony south-facing slope, 10.ix.2013, C. Kropf and L. Sentenská (NMPC).

Paratypes. Switzerland: Baselland: Langenbrück, $47.348^{\circ} \mathrm{N}, 7.767^{\circ} \mathrm{E}$, 14 f, 7 \&, 3 juv., E. Schenkel (NMB: ARAN-00156a-b); Meistelberg,

45 Liesberg, $47.408^{\circ} \mathrm{N}, 7.436$, Quercus forest, altitude $560 \mathrm{~m}, 1$ ô, 11-26. vi.1995, C. Berney (NMB: ARAN-00156ac).

Other material. See Supplementary material file.

\section{Diagnosis}

Dysdera kropfi is morphologically and molecularly almost of chromosomes $(2 \mathrm{n} \hat{0}=15)$, and details on the bulbus (more distinct constriction in the middle of the tegulum, Fig. 5J; $D$. erythrina: Fig. $5 E$; posterior apophysis more diverted from the bulbus, Fig. $11 \mathrm{~J} ;$ D. erythrina: Fig. $11 E$ ) and vulva (straight anterior margin of spermatheca, without sclerotised teeth, anterior margin of dorsal arch with shoulders, Fig. $12 N ; D$. erythrina: Fig. 12D).

\section{Intraspecific variation}

Carapace length 3.1-3.7 mm; 4-6 spines on the ventral side of the leg IV tibia; bulb length $1.2-1.4 \mathrm{~mm}$.

Habitat

Xerothermic open forest on south-facing slopes.

\section{Distribution}

Swiss canton Baselland. Morphologically similar material also comes from other regions of the western Alps in Switzerland (Wallis, Aargau and Jura) and southern Germany, but we were not able to confirm the identity of these populations by karyological survey.

\section{Etymology}

Named after Christian Kropf, an Austrian arachnologist based in 20 Switzerland who helped to discover this species.

\section{Dysdera lantosquensis Simon}

(Figs $3 K, 5 K, 6 K, 8 K, 9 K, 10 K, 11 K, 12 O, 13,14,15 I$ )

Dysdera lantosquensis Simon, 1882: 215. Type locality: France: Alpes Maritimes: Saint Martin Vésubie near Lantosque. We did not find the designated type material in Simon's collection in the MNHN.

Dysdera erythrina lantosquensis: Simon, 1914: 99, 113 (ठ̊).

Dysdera lantosquensis: Rezáč et al. 2007 (misidentification).

\section{Material examined}

We used the following specimen for redescribing the species: 1 , Italy: Genova, $44.4192^{\circ} \mathrm{N}, 8.9933^{\circ} \mathrm{E}$, ruins on pasture, 11.xi.2011, J. Dolanský (NMPC). We selected this specimen because it was used also for karyotype study.

Other material. See Supplementary material file.

\section{Diagnosis}

Dysdera lantosquensis is among the smallest species of the complex. It differs, together with $D$. cechica, from the other species in: (1) the dark brown, relatively high and short, roughly wrinkled carapace (Fig. $3 K$; D. cechica: Fig. 3C); (2) the mediodorsally very concave basal cheliceral segment; (3) the male bulb with its relatively large, almost pointed (Fig. 10K; D. cechica: Fig. 10C) curved posterior apophysis without a tooth on its proximal side (Fig. 11K; D. cechica: Fig. 11C); and (4) the wide spermatheca with concave anterior margin and lateral edges incurvated backwards, the conspicuous folds on the lateral parts of the spermatheca in ventral view (Fig. 12O;D. cechica: Fig. 12C), and anterior margin of the dorsal arch with small shoulders. Adults possess long hairs on the dorsal side of the opisthosoma. It differs from the morphologically very similar D. cechica in that the distal half of the tegulum is markedly wider 
than its proximal half in the male bulb (Fig. $5 K$; D. cechica: Fig. $5 C$, arrows).

\section{Intraspecific variation}

Carapace length $2.2-3.1 \mathrm{~mm}$; three or four spines on the ventral

\section{Remarks}

The only vial in the MNHN labelled as D. lantosquensis (Martigues, xi.1913, AR5877, 25195) was empty. The type material of this species was probably later mixed with other

10 material - specimens of this species were found among other species of the complex in the vial labelled ' $D$. erythrina, France' stored at the MNHN. Original descriptions of this species did not include drawings. However, its identity can be deduced from the verbal description (Simon 1882) and diagnosis (Simon 1914).

15 Simon described it as a species with a very dark, relatively short, strongly wrinkled carapace, strong tooth-like posterior apophysis, and only three spines on the ventral (including proand retroventral) side of the leg IV tibia.

The material from Austria, Czechia, Hungary and Slovakia

20 referred as D. lantosquensis in Rezáč et al. (2007) belongs to D. cechica.

\section{Habitat and phenology}

This species occurs in Mediterranean forests (mainly Quercus, less often Fagus and Abies), Mediterranean bush and shaded

25 parts of dry grassland. It is also common in planted forests (e.g. Pinus), orchards (e.g. Olea, Castanea) and vineyards, especially surrounding ruins. It was also found in wetlands with Phragmites, with seashore halophile vegetation, or habitats with rural vegetation.

\section{Distribution}

Dysdera lantosquensis occurs mainly in northern Italy, Corsica and on the French side of the Alpes Matitimes (Fig. 13). The single location in southern Catalonia should be subject to further confirmation using molecular data. Because of its occurrence 35 close to the borders between Italy and Slovenia (Gorizia, $45.94^{\circ} \mathrm{N}$, $13.62^{\circ} \mathrm{E}$ ), it may also occur in western Slovenia. In central Europe, it is replaced by the vicariant species $D$. cechica.

\section{Dysdera minairo Řezáč, sp. nov.}

(Figs $3 L, 5 L, 6 L, 8 L, 9 L, 10 L, 11 L, 12 P, 13,14,15 H$ )

http://zoobank.org/urn:lsid:zoobank.org:act:E03B8610-27BC-419CBE11-7BF2513C5B19

\section{Material examined}

Holotype. Ŝ, Spain: Catalonia: Lleida: Planes de Son, $42.61361^{\circ} \mathrm{N}$, $1.08278^{\circ} \mathrm{E}, 1525 \mathrm{~m}$, Pinus uncinata forest, 10.vi.2011, C. Ribera (CRBA

Parater

Paratypes. Spain: Catalonia: Lleida: Cadí-Moixeró Natural Park, Riu de Cerdanya, $42.323^{\circ} \mathrm{N}, 1.817^{\circ} \mathrm{E}, 1472 \mathrm{~m}$, Abies forest, 1 \%, 16.iv.2003, M. Arnedo and E. De Mas (CRBA 000402, k495); Estany de Montcortés, $42.330839^{\circ} \mathrm{N}, 0.995197^{\circ} \mathrm{E}, 1030 \mathrm{~m}$, submediterranean evergreen oak forest,

502 क, 9.viii.2007, N. Macías-Hernández and S. de la Cruz (CRBA VO000112-3); Montsde Rúbies, Hostal Roig trail, $42.03672^{\circ} \mathrm{N}$, $0.00032^{\circ} \mathrm{E}, 1154 \mathrm{~m}$, Quercus suber forest, under stones, 1 , 27.ii.2007,
M. Arnedo, V. Opatova, L. Bidegaray-Batista and N. Macías-Hernández (CRBA VO000032); Planes de Son, $42.61361^{\circ} \mathrm{N}, 1.08278^{\circ} \mathrm{E}, 1525 \mathrm{~m}$, Pinus uncinata forest, 1 ^ิ, 1 †, 7.ix.2008, M. Arnedo, L. Bidegaray-Batista and N. Macías-Hernández (CRBA 1701, CRBA 1699); 1 + , 10.vi.2011, C. Ribera (CRBA 002037); Rasos de Paguera, near Castellar del Riu, 42.13917º , $1.75917^{\circ} \mathrm{E}, 1$ 今, 6.x.2008, M. Arnedo (CRBA 1721).

Other material. See Supplementary material file.

\section{Diagnosis}

Similar to $D$. pyrenaica, but larger. Bulb of $D$. minairo possesses a more prominent lump (Fig. 5L; D. pyrenaica: Fig. 5O) and more prominent lobate posterior apophysis, without a tooth on its proximal side (Fig. 11L, arrow; D. pyrenaica: Fig. 11O). The proximal part of the arch-like ridge gradually protrudes from the outline of the bulb (Fig. $8 L$ ), but not at a right angle as seen in D. pyrenaica (Fig. 80). The vulva is characterised by a wide spermatheca with the lateral parts markedly bent distally, and an almost straight anterior margin of the dorsal arch (Fig. 12P).

\section{Intraspecific variation}

Carapace length 3.4-4.5 mm; 3-6 spines on the ventral side of the leg IV tibia; bulb length $1.2-1.3 \mathrm{~mm}$.

\section{Habitat}

From subalpine (Abies, Pinus uncinata) to submediterranean forest (Quercus suber, Q. ilex), usually above $1000 \mathrm{~m}$.

\section{Distribution}

Across the eastern and central parts of the Catalan Pyrenees and pre-Pyrenees (Cadí, Montsec) ranges.

\section{Etymology}

Most of the specimens of this species come from the Pallars country in the western Catalan Pyrenees. In local folklore, 'minairons' are a kind of gnome supposedly born under a local plant. We use the name 'minairo' (singular) in aposition.

Dysdera portsensis Řezáč, sp. nov.

(Figs $2 H, 3 M, 5 M, 6 M, 7 F, 8 M, 9 M, 10 M, 11 M, 12 F, 13,14,15 L$ )

http://zoobank.org/urn:1sid:zoobank.org:act:24CDE6AA-6316-455BA165-100F074E0BF1

\section{Material examined}

Holotype. $\hat{\jmath}$, Spain: Catalonia: Tarragona: Ports de Beseit Natural Park, Cova del Vidre, $40.764^{\circ} \mathrm{N}, 0.309^{\circ} \mathrm{E}, 13 . v i .2002$, E. De Mas (CRBA VO000054).

Paratypes. Spain: Catalonia: Tarragona: Ports de Beseit Natural Park, Cova del Vidre, $40.764^{\circ} \mathrm{N}, 0.309^{\circ} \mathrm{E}, 1$ 今ै, 13.vi.2002, E. De Mas (CRBA VO000055); Ports de Beseit Natural Park, along the valley Galera, $40.745^{\circ} \mathrm{N}$, 0.333 ${ }^{\circ}$ E, 2 今ै, 31.v.2002, E. De Mas (CRBA VO000056-7); Ports de Beseit Natural Park, along the valley Galera, $40.737^{\circ} \mathrm{N}, 0.338^{\circ} \mathrm{E}, 1$ o, $31 . v .2002$, E. De Mas (CRBA VO000058); Ports de Beseit Natural Park, near Cova del 45 Vidre, $40.770^{\circ} \mathrm{N}, 0.314^{\circ} \mathrm{E}$, Pinus forest, 1 今 ${ }^{\circ} 1$ \% , 28.iv.2009, M. Řezáč (MR).

Other material. See Supplementary material file.

\section{Diagnosis}

Among the species of the D. erythrina-complex, D. portsensis is unique in that males have a roughly wrinkled basal cheliceral 
segment on the frontal side (Fig. 2H). Further, it is characterised by a small body size, relatively long legs, relatively long hairs on the dorsal opisthosoma of adults, elongated distal part of the basal cheliceral segment (Fig. $2 \mathrm{H}$, the cheliceral teeth are positioned 5 relatively more proximally), a pale prosoma (Fig. $3 M$ ), a very wrinkled, relatively long carapace (Fig. $2 H$ ), and by the shape of the copulatory organs, especially the bulb with very small, pointed (Fig. 10M), straight posterior apophysis without a tooth on its proximal side (Fig. 11M), and a very wide, regularly domed

10 and smooth lump (Figs $5 M, 7 F$ ). This large lump makes the distal half of the tegulum much wider than the proximal half, in retrolateral view. It differs from the very similar $D$. undecima and $D$. tredecima by ferruginous rather than reddish carapace (Fig. 3M; D. undecima: Fig. 3T; D. tredecima: Fig. 3S) and the 15 shape and relative size of the bulb. The bulb of $D$. portsensis is larger; the distal division is relatively shorter and less inclined with regards to the tegulum in retrolateral view (Fig. 5M; D. undecima: Fig. 5T; D. tredecima: Fig. 5S). Furthermore, it differs from $D$. undecima and $D$. tredecima in a relatively larger membranous patch (Fig. $5 M$, arrow), the lateral sheet not covering the fissure (Fig. $7 F$; D. undecima: Fig. $7 L$ ), and a roughly wrinkled carapace (Fig. $2 H$; D. undecima: Fig. $2 K$ ).

\section{Intraspecific variation}

Carapace length 2.6-2.9 mm; three or four ventral spines on the

25 leg IV tibia; bulb length $1.22-1.35 \mathrm{~mm}$.

\section{Habitat}

Dysdera portsensis was found in montane Pinus forest.

\section{Distribution}

Known only from the Ports Massif in Catalonia, north-eastern

Iberian Peninsula (Fig. 13).

\section{Etymology}

Named after the Ports Massif, where the species occurs. This massif is located on the north-eastern end of the Iberian mountain range. The suffix '-ensis' means place.

\section{Dysdera pradesensis Řezáč, sp. nov.}

(Figs $2 I, 3 N, 5 N, 6 N, 7 G, 8 N, 9 N, 10 N, 11 N, 12 G, 13,14,15 G$ )

http://zoobank.org/urn:lsid:zoobank.org:act:B23B7863-1BD9-454EA18B-44993E82F0FF

\section{Material examined}

Holotype. $\hat{\jmath}$, Spain: Catalonia: Tarragona: Serra de Prades, Barranc de la Font d'en Garro, $41.355^{\circ} \mathrm{N}, 1.086^{\circ} \mathrm{E}$, 28.v.2003, M. A. Arnedo and E. De Mas (CRBA 000505).

Paratypes. Spain: Catalonia: Barcelona: Montserrat, $41.6^{\circ} \mathrm{N}, 1.8^{\circ} \mathrm{E}$, 1 o (MR); Tarragona: Serra de Prades, Barranc de la Font d'en Garro,

$4541.355^{\circ} \mathrm{N}, 1.086^{\circ} \mathrm{E}, 1$ , 28.v.2003, M. A. Arnedo and E. De Mas (CRBA 000505); Poblet Natural Park, Poblet town, $41.372^{\circ} \mathrm{N}, 1.086^{\circ} \mathrm{E}$, Laurus nobilis and Arbutus unedo forest, 1 ô, 1 juv., 29.iv.2009, M. Řezáč (MR).

Other material. See Supplementary material file.

\section{Diagnosis}

50 Dysdera pradesensis is characterised by relatively long legs and the shape of the bulb, which exhibits short distal division in relation to the tegulum (Fig. $5 N$ ), a robust tegulum with a pronounced, remarkably striated lump (Fig. 7G), and a relatively large curved obtuse posterior apophysis (Fig. 10N) without a tooth on its proximal side (Fig. 11N). The bulbs of $D$. erythrina, D. pyrenaica and $D$. quindecima are similar, but possess this tooth (D. erythrina: Fig. $11 E$; D. pyrenaica: Fig. 110 ; D. quindecima: Fig. 11P).

\section{Intraspecific variation}

Carapace length 3.3-3.9 mm; three or four spines on the ventral side of leg IV tibia; bulb length $1.20-1.44 \mathrm{~mm}$.

Habitat

Dysdera pradesensis was found in mountain forest dominated by Pinus sylvestris, Laurus nobilis and Arbutus unedo, above $500 \mathrm{~m}$ elevation.

\section{Distribution}

This species is known from two massifs (Serra de Prades, Montserrat) on the Catalan Pre-Coastal Range, on the northeastern Iberian Peninsula (Fig. 13). Its occurrence in France is dubious.

\section{Etymology}

Named after Serra de Prades, a calcareous massif part of the Catalan Pre-Coastal Range, from where the type material of this species comes. The suffix '-ensis' means place.

Dysdera pyrenaica Řezáč, sp. nov.

(Figs 3O, 5O, 6O, 7H, 8O, 9O, 10O, 11O, 12H, 13, 14, 15D, 16A)

http://zoobank.org/urn:lsid:zoobank.org:act:F503DEC9-C927-4111A0D5-B33D8D855871

\section{Material examined}

Holotype. Sô, Spain: Catalonia: Lleida: Cadí-Moixeró Natural Park, Riu de Cerdanya, $42.336^{\circ} \mathrm{N}, 1.826^{\circ} \mathrm{E}$, Pinus forest, 1.v.2009, M. Řezáč (NMPC).

Paratypes. Spain: Catalonia: Lleida: Cadí-Moixeró Natural Park, Riu de Cerdanya, $42.336^{\circ} \mathrm{N}, 1.826^{\circ} \mathrm{E}$, Pinus forest, 1 ô, 7 o, 1.v.2009, M. Řezác (MR).

Other material. See Supplementary material file.

\section{Diagnosis}

Dysdera pyrenaica differs from the other species of the complex (including similar $D$. pradesensis and D. quindecima) in a relatively long and smooth carapace (Fig. 3O) and the shape of the copulatory organs. The bulb is similar to that of $D$. pradesensis and $D$. erythrina. In contrast to $D$. pradesensis, the membranous patch of the bulb is relatively larger (Fig. 5O, arrow; D. pradesensis: Fig. $5 N$ ), and the proximal part of the archlike ridge protrudes from the outline of the bulb almost at a right angle in hind view (Fig. 8O, arrow; D. pradesensis: Fig. 8N). In contrast to $D$. erythrina, the membranous patch of the bulb is relatively smaller (Fig. 5O, arrow; D. erythrina: Fig. 5E); the posterior apophysis is placed more distally, and does not exceed the lump in lateral view (Fig. 60, arrow; D. erythrina: Fig. $6 E$ ). The spermatheca of $D$. pyrenaica differs from that in D. pradesensis by an almost straight anterior margin (Fig. 12H; 5

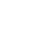


D. pradesensis: Fig. 12G). Moreover, the ventral wall, especially in the vicinity of the medial groove, is equipped with sclerotised spots.

\section{Intraspecific variation}

5 Carapace length 3.2-3.4 mm; bulb length $1.2-1.4 \mathrm{~mm}$.

\section{Habitat}

Mountain forests dominated by Pinus sylvestris and Abies alba, at around $1000 \mathrm{~m}$ elevation.

\section{Distribution}

10 Known only from the Catalonian south-eastern Pyrenees on the north-eastern Iberian Peninsula (Fig. 13). It is also likely to occur in France.

\section{Etymology}

Named after the Pyrenees, the mountain range where this species occurs.

Dysdera quindecima Řezáč, sp. nov.

(Figs $3 P, 5 P, 6 P, 7 I, 8 P, 9 P, 10 P, 11 P, 12 Q, 13,14,15 M, 16 E$ )

http://zoobank.org/urn:lsid:zoobank.org:act:451AC0DC-39CD-4FC59B31-B2851B055B74

\section{Material examined}

Holotype. ô, Spain: Catalonia: Barcelona: Montseny Natural Park, Font de Passavets, Santa Fe, $41.78083^{\circ} \mathrm{N}, 2.45222^{\circ} \mathrm{E}, 1222 \mathrm{~m}$, Fagus sylvatica forest, 11.iv.2008, M. Arnedo, V. Opatova, L. Bidegaray-Batista and N. Macías-Hernández (CRBA VO000129).

Paratypes Spain: Catalonia: Barcelona: Montseny Natural Park, Font de Passavets, Santa $\mathrm{Fe}, 41.7808^{\circ} \mathrm{N}, 2.4522^{\circ} \mathrm{E}, 1222 \mathrm{~m}$, Fagus forest, 2 ㅇ, 11.iv.2007, M. Arnedo, V. Opatova, L. Bidegaray-Batista and N. MacíasHernández (CRBA VO000122, 130); ibidem, $41.774^{\circ} \mathrm{N}, 2.460^{\circ} \mathrm{E}$, Fagus forest, 3 \%, 18.v.2007, M. Arnedo, V. Opatova, L. Bidegaray-Batista and

30 N. Macías-Hernández (CRBA VO000074, 76, 79); Turó de l'Home Mt., $41.776^{\circ} \mathrm{N}, 2.445^{\circ} \mathrm{E}$, Fagus forest, 1 +, 30. iv.2009, M. Řezáč (MR) (CRBA VO000015).

Other material. See Supplementary material file.

\section{Diagnosis}

35 Dysdera quindecima differs from the other species of the complex in the shape of the copulatory organs. This species is similar to $D$. pradesensis, D. erythrina and especially $D$. pyrenaica, but its carapace is darker (Fig. $3 P$; D. pradesensis: Fig. $3 N$; D. erythrina: Fig. $3 E$; D. pyrenaica: Fig. $3 O$ ). In contrast to $D$. pradesensis, the

40 membranous patch of bulb is relatively larger (Fig. $5 P$, arrow; D. pradesensis: Fig. $5 N$ ) and the proximal part of the arch-like ridge protrudes from the outline of the bulb almost at a right angle in hind view (Fig. 8P, arrow; D. pradesensis: Fig. 8N). In contrast to $D$. erythrina, the membranous patch of bulb is 45 relatively smaller (Fig. $5 P$, arrow; D. erythrina: Fig. $5 E$ ); the posterior apophysis is placed more distally (Figs 7I, 6P, arrows; $D$. erythrina: Figs $7 D, 6 E$ ) and it does not exceed the lump in lateral view. The bulb of $D$. quindecima differs from that of $D$. pyrenaica by a longer distal division in relation to the tegulum

50 (Fig. 5P; D. pyrenaica: Fig. 5O), and by the posterior apophysis being equipped with a pronounced tooth on its proximal side
(Fig. 11P, arrow; D. pyrenaica: Fig. 11O). The vulva of $D$. quindecima is characterised by conspicuous folds on the lateral parts of the spermatheca, concave anterior margin of the spermatheca and an almost straight anterior margin of the dorsal arch.

\section{Intraspecific variation}

Carapace length 3.3-4.5 mm; three or four spines on the ventral side of the leg IV tibia.

\section{Habitat}

Dysdera quindecima was found in Fagus sylvatica forest, at an 10 altitude of $\sim 1000 \mathrm{~m}$

\section{Distribution}

Known only in the Montseny Mts, part of the Catalan Pre-Coastal Range, on the north-eastern Iberian Peninsula (Fig. 13).

Etymology

'Quindecima' is a Latin expression for fifteen, the chromosome number of males of this species. This chromosome number is unique among the six species of the $D$. erythrina-complex found in the Montseny Mts, the presently known distribution area of D. quindecima.

Dysdera septima Řezáč, sp. nov.

(Figs $3 Q, 5 Q, 6 Q, 7 J, 8 Q, 9 Q, 10 Q, 11 Q, 13,14,15 A$ )

http://zoobank.org/urn:lsid:zoobank.org:act:23B2D8F9-6DBC-4A599640-8D710F617265

\section{Material examined}

Holotype. ô, Spain: Catalonia: Barcelona: Montseny Natural Park, Camping Can Cervera, $41.7700^{\circ} \mathrm{N}, 2.4041^{\circ} \mathrm{E}, 30$. iv.2009, M. Řezáč (NMPC).

Paratypes. Spain: Catalonia: Barcelona: Montseny Natural Park, Camping Les Piscines, $41.7610^{\circ} \mathrm{N}, 2.3889^{\circ} \mathrm{E}, 1$ ô, 30.iv.2009, M. Řezáč (MR); Montseny Natural Park, Camping Can Cervera, $41.7700^{\circ} \mathrm{N}, 2.4041^{\circ} \mathrm{E}$, 1 †, 30.iv.2009, M. Řezáč (NMPC, CRBA VO000018).

Other material. See Supplementary material file.

\section{Diagnosis}

Dysdera septima is among the smallest species of the complex and is characterised by relatively long chelicerae and legs. This species is very similar to $D$. erythrina. It differs by (1) a smaller body, (2) a smoother carapace (Fig. 3Q; D. erythrina: Fig. 3E), (3) and details of the bulb. In particular, the distal division of the bulb is shorter relative to the tegulum (Fig. $5 Q ; D$. erythrina: Fig. $5 E$ ); the posterior apophysis of the bulb does not exceed the lump in lateral view (Fig. 6Q, arrow; D. erythrina: Fig. 6E); the margin of the distal half of the distal division opposite the lateral sheet is not convex in lateral view (Fig. 5Q, arrow; D. erythrina: Fig. $5 E$ ); the proximal part of the arch-like ridge protrudes almost at a right angle from the outline of the bulb (Fig. 8Q, arrow; 45 D. erythrina: Fig. 8E).

\section{Intraspecific variation}

Carapace length 2.4-2.8 mm. 


\section{Habitat}

Dysdera septima was found in Quercus forest.

\section{Distribution}

Known only from the Montseny Mts, part of the Catalan Pre5 Coastal Range, on the north-eastern Iberian Peninsula (Fig. 13).

\section{Etymology}

'Septima' is a Latin expression for seven, the number of chromosomes in males of this species. This chromosome number is not only unique among six species of the

10 D. erythrina-complex from Montseny Mts, but also the lowest in the genus Dysdera.

\section{Dysdera stahlavskyi Řezáč, sp. nov.}

(Figs $2 J, 3 R, 5 R, 6 R, 7 K, 8 R, 9 R, 10 R, 11 R, 12 I, 13,14,15 C$ )

http://zoobank.org/urn:lsid:zoobank.org:act:576FB80F-EED4-4FDDB47A-5966AFF16D3B

\section{Material examined}

Holotype. $\widehat{\jmath}$, France: Var: Trigance, Grand Canyon, Balcons de la Mescla, $43.731^{\circ} \mathrm{N}, 6.387^{\circ} \mathrm{E}$, deciduous Quercus forest with Buxus shrubs, 25.iv.2009, J. Dolanský, E. Líznarová and M. Řezáč (NMPC).

20 Paratypes. France: Var: Trigance, Grand Canyon, Balcons de la Mescla, $43.759^{\circ} \mathrm{N}, 6.311^{\circ} \mathrm{E}, 1$ ô, 13.vi.2007, F. Št áhlavský (MR); Var, Trigance, Grand Canyon, Balcons de la Mescla, $43.731^{\circ} \mathrm{N}, 6.387^{\circ} \mathrm{E}$, deciduous Quercus forest with Buxus shrubs, 2 +, 25.iv.2009, J. Dolanský, E. Líznarová and M. Řezáč (MR).

Other material. See Supplementary material file.

\section{Diagnosis}

Dysdera stahlavskyi is among the smallest species of the complex. It differs from the other species by the shape of the copulatory organs, especially by the slender and straight bulb:

30 tegulum and distal division are in line in retrolateral view (Figs $5 R, 6 R, 7 K$ ). The membranous patch is almost absent. The lateral sheet overlaps the fissure between the lateral sheet and the distal projection. The distal projection forms a lobe in its proximal part (Fig. $7 \mathrm{~K}$, left arrow), which partly covers the

35 fosette inside the arch-like ridge, and protrudes forwards from the distal part of the bulb (Fig. $7 K$, right arrow). The spermatheca is characterised by lateral edges that are remarkably incurvated backwards (Fig. 12I, arrow). Moreover, D. stahlavskyi differs from other species of the complex (except for D. cechica,

40 D. lantosquensis, D. garrafensis and D. portsensis) by relatively long $(\sim 0.1 \mathrm{~mm})$ setae on the dorsal side of the opisthosoma and, except for $D$. corallina, by long setae on the clypeus (Fig. $2 J$; D. corallina: Fig. $2 D$ ).

\section{Intraspecific variation}

Carapace length $2.0-4.3 \mathrm{~mm} ; 3-5$ spines on the ventral side of the leg IV tibia; bulb length $0.95-1.24 \mathrm{~mm}$.

\section{Remarks}

Simon probably used the specimens belonging to this species, together with similar but not conspecific material from Corsica, material in the publication or on the vial label. We located the material from Corsica used in the original description of $D$. fervida in its own vial, but the material from Provence was probably later mixed with other material of the $D$. erythrinacomplex. We found specimens fitting the original description of 5 $D$. fervida among other species of the $D$. erythrina-complex in the vial labelled ' $D$. erythrina, France' stored at the MNHN. To fix the identity of $D$. fervida, we designate a male syntype from Corsica as its lectotype and name the related species from continental France as D. stahlavskyi.

Habitat

Mediterranean Quercus forest and bush.

Distribution

Dysdera stahlavskyi is found in southern France, particularly the Var and Alpes de Haute Provence districts (Fig. 13).

\section{Etymology}

Named after the Czech arachnologist František Št áhlavský, a colleague who helped to discover this species.

Dysdera tredecima Řezáč, sp. nov.

(Figs $3 S, 5 S, 6 S, 8 S, 9 S, 10 S, 11 S, 12 R, 13,14,15 J$ )

http://zoobank.org/urn:lsid:zoobank.org:act:07D5CE61-CC31-442C8B70-907A6693C531

\section{Material examined}

Holotype. ô, Spain: Catalonia: Barcelona: Montseny Natural Park, Camping Les Piscines, $41.7610^{\circ} \mathrm{N}, 2.3889^{\circ}$ E, 30.iv.2009, M. Řezáč (NMPC).

Paratypes. Spain: Catalonia: Barcelona: Montseny Natural Park, Sot del Bernadal, $41.76139^{\circ} \mathrm{N}, 2.44778^{\circ} \mathrm{E}, 1128 \mathrm{~m}, 1$ +, $2 . v i .2004$, G. Giribet (CRBA 0001363); Montseny Natural Park, Camping Can Cervera, $41.7699^{\circ} \mathrm{N}, 2.4042^{\circ} \mathrm{E}$, humid Platanus forest, 2 \%, 9.ix.2006, M. Řezác (MR) (V28, V30, CRBA VO000014, CRBA VO000016).

Other material. See Supplementary material file.

\section{Diagnosis}

Dysdera tredecima is characterised by: (1) a small body size; (2) a pale, low, very wrinkled, relatively long carapace (Fig. 3S); and (3) specific morphology of the male bulb, namely, a very small, pointed (Fig. 10S), straight posterior apophysis without a tooth on its proximal side (Fig. 11S). This species is very similar to D. undecima. The bulb differs from that of $D$. undecima by being more contracted in the middle of the retrolateral side of the tegulum (visible from hind view, when the posterior apophysis is inclined towards the observer, Fig. 8S; D. undecima: Fig. 8T). Furthermore: (1) the haematodocha on the distal half of the distal division, opposite the posterior apophysis, is convex in retrolateral view (Fig. $5 S$, arrow; it is straight in $D$. undecima: Fig. 5T, arrow); (2) the tip of the posterior apophysis is markedly incurvated towards the prolateral side (Fig. 10S, arrow; D. undecima: Fig. 10T); and (3) in retrolateral view, the haematodocha and the lateral sheet contain smaller angles than are seen in D. undecima (Fig. 6S, arrow; D. undecima: Fig. 6T). The vulva is characterised by a convex anterior margin of the spermatheca, the absence of folds on the lateral parts of the 
spermatheca, and shoulders on the anterior margin of the dorsal arch.

\section{Habitat}

Dysdera tredecima was found in Quercus ilex and Platanus 5 forest.

\section{Distribution}

Known only from the Montseny Mts, part of the Catalan PreCoastal Range on the north-eastern Iberian Peninsula (Fig. 13).

\section{Etymology}

10 'Tredecima' is a Latin expression for thirteen, the chromosome number of males of this species. This chromosome number is unique among species of the D. erythrina-complex from Montseny Mts.

\section{Dysdera undecima Řezáč, sp. nov.}

15 (Figs $2 K, 3 T, 5 T, 6 T, 7 L, 8 T, 9 T, 10 T, 11 T, 12 J, S, 13,14,15 F$ )

http://zoobank.org/urn:lsid:zoobank.org:act:21737A6E-E7CD-47F69082-43A4A49EB01D

\section{Material examined}

Holotype. ô, Spain: Catalonia: Barcelona: Montseny Natural Park, 20 Camping Can Cervera near Montseny town, $41.7699^{\circ} \mathrm{N}, 2.4042^{\circ} \mathrm{E}$, humid Platanus forest, 9.ix.2006, M. Řezáć (NMPC).

Paratypes. Spain: Catalonia: Barcelona: Montseny Natural Park, along the road from Sant Celoni to Turó de l'Home, 1 + , 9.vi.2002, E. De Mas (CRBA VO000038); Montseny Natural Park, Turó de l'Home Mt., $41.776^{\circ} \mathrm{N}$,

$252.445^{\circ} \mathrm{E}$, Fagus forest, 2 \%, 10.ix.2006, 1 ô, 1 + , 30.iv.2009, M. Řezáč (MR); Montseny Natural Park, Camping Les Piscines, $41.7610^{\circ} \mathrm{N}, 2.3889^{\circ} \mathrm{E}$, Quercus ilex and Platanus forest, 1 ô, 30.iv.2009, M. Řezáč (MR).

Other material. See Supplementary material file.

\section{Diagnosis}

30 Within the D. erythrina-complex, D. undecima is characterised by: (1) small body size; (2) a pale (Fig. 3T), low, very wrinkled, relatively long carapace (Fig. $2 K$ ); (3) the mophology of the male bulb, namely, very small, pointed (Fig. 10T) and straight posterior apophysis without a tooth on its proximal side (Fig. 11T); and

35 (4) a vulva with a relatively wide medial groove (Fig. 12J) with sclerotised spicules inside. This species is very similar to D. tredecima. In comparison with this species, D. undecima has a more wrinkled carapace (Fig. 3T; D. tredecima: Fig. 3S), which is more convex behind the eyes. Furthermore, the lateral

40 sides of the thoracic part are more rounded. The ventral side of the leg IV tibia of $D$. undecima is usually equipped with four spines, while in D. tredecima it has three spines.

\section{Intraspecific variation}

Carapace length $2.8-3.5 \mathrm{~mm}$; $3-5$ spines on the ventral side of

\section{Habitat}

Dysdera undecima was found in relatively humid Platanus, Fagus and Quercus forests.

\section{Distribution}

Known only from the Montseny Mts, part of the Catalan Pre-Coastal Range, on the north-eastern Iberian Peninsula (Fig. 13).

\section{Etymology}

'Undecima' is a Latin expression for eleven, the chromosome number of males of this species. This chromosome number is unique among species of the $D$. erythrina-complex from Montseny Mts.

\section{Natural history observations}

Prey preference

All species readily captured woodlice. In cases when some specimens refused woodlice, they also refused flies. All species used both the pincers and fork tactics to grasp woodlice. Most species used the pincers tactic significantly more $(P<0.05$, exact binomial test, compared with equal frequency $50 \%$ ) with the exceptions of $D$. cechica and $D$. lantosquensis, which used the fork tactic significantly more $(P<0.05$, exact binomial test).

\section{Interspecific mating}

In intraspecific pairings, all males and females of both selected species (D. erythrina, D. cechica) copulated. In interspecific crosses, all male $D$. cechica and female $D$. erythrina mated (because of methodological obstacles, the progeny was not tracked). In contrast, no female $D$. cechica mated with any male D. erythrina.

\section{Molecular data}

The taxa used in the molecular analyses, along with the locality information and the GenBank accession numbers are listed in Table S1. All species except for D. dolanskyi and D. graia were included in the analyses. Eighty-two specimens of the D. erythrina-complex were sequenced for $C O I$ and 16 additional sequences were retrieved from GenBank. In total, 98 sequences representing 80 unique haplotypes were available for barcoding analyses.

The uncorrected average interspecific distance among sequences of the $D$. erythrina-group was $11.77 \%$. The largest intraspecific distance was $7.40 \%$, within $D$. shardana haplotypes, while the smallest interspecific distances corresponded to D. kropfi and D. erythrina $(0.15 \%)$, and D. tredecima and D. undecima (1.18\%) (Fig. 14).

Unlinked models were assigned to each codon partition, as selected by PartitionFinder. The gene trees inferred with the Bayesian and maximum likelihood methods were largely congruent and only differed in poorly supported groups. Species defined on morphological and karyological grounds were resolved as monophyletic groups, with few exceptions. The single analysed specimen of $D$. kropfi nested within the sequences identified as $D$. erythrina, while $D$. lantosquensis was recovered as paraphyletic with regards to D. cechica; similarly, $D$. minairo with regards to $D$. pradesensis. Finally, the clade formed by haplotypes of $D$. catalonica also included one haplotype morphologically identified as $D$. corallina, 
closely related to a haplotype of $D$. catalonica from the same locality.

A large clade including all species other than $D$. jana, D. shardana, D. fervida, D. stahlavskyi, D. lantosquensis and

5 D. cechica received high support (ML bootstrap $>80 \%$, posterior probability $>0.95$ ). Other clades supported in both the Bayesian and maximum likelihood analyses included: (1) D. erythrinal $D$. kropfi as sister group to D. corallina; (2) the clade including the species $D$. portsensis, $D$. garrafensis, $D$. tredecima and

$10 D$. undecima, the two last species forming a well-supported clade; (3) D. pradesensis and D. minairo; and (4) the clade including $D$. quindecima, $D$. fabrorum and $D$. catalonica. The latter clade was also supported by morphological apomorphies, namely, the small pointed posterior apophysis without a tooth 15 on its proximal side and with a smooth lump. Similarly, although poorly supported by molecular data, the clade including $D$. pradesensis, D. minairo and D. pyrenaica was supported by an autapomorphic hooked, obtuse posterior apophysis in the bulb.

20 Results of the different clustering methods are summarised in Fig. 14. The 21 phenotypic species were resolved as 16 (confidence interval 4-53) and 19 (confidence interval 5-52) GMYC clusters using the Bayesian (GMYC-B) and ML (GMYCML) approaches, respectively. In both cases, the GMYC model 25 provided a significantly better fit than the single lineage null model $(P=0.05)$. The PTP approach recovered 24 clusters and TCS identified 28 independent haplotype networks.

All methods were largely congruent, in the sense that the increase in the number of clusters was the result of splitting more30 inclusive clusters. All molecular clustering methods agreed in splitting some phenotypic species into further clusters. In a few cases, however, phenotypic species were grouped into a single cluster: $D$. tredecima and $D$. undecima were grouped in the same cluster by all methods; $D$. minairo and $D$. pradesensis as 35 well as $D$. portsensis and D. garrafensis were grouped together by GMYC-B; and D. lantosquensis and $D$. cechica as well as $D$. erythrina and D. corallina were grouped together under both GMYC-B and GMYC-ML.

\section{Karyotypes}

40 We analysed karyotypes of most species of the D. erythrinacomplex. The number of autosome pairs ranged from three (D. septima) to nine (D. corallina, D. erythrina, D. dolanskyi) (Table S4). Analysis of male meiosis showed that all species share the sex chromosome system X0 (Fig. 16A-H) except for

45 D. dolanskyi, which displayed an $\mathrm{X}_{1} \mathrm{X}_{2} 0$ system (Fig. 16I-O). Species with the same diploid number differed in the length of one to several autosome pairs and/or the sex chromosome (Table S4). Relative length of the $\mathrm{X}$ chromosome in the $\mathrm{X} 0$ system varied considerably, ranging from $20.8 \%$ (D, erythrina) to $29.0 \%$ of 50 the total length of the haploid set (D. catalonica). The $\mathrm{X}$ chromosome was shorter than the autosomes in D. septima, $D$. pyrenaica and $D$. pradesensis. In $D$. fervida, D. minairo, $D$. undecima and $D$. tredecima, the $\mathrm{X}$ chromosome was only slightly longer than the longest autosomes. The $\mathrm{X}$ chromosome

55 was remarkably longer than the autosomes in all species with $2 \mathrm{n} \geq 15$ and also in D. catalonica $(2 \mathrm{n} \hat{O}=9)$, D. cechica $(2 \mathrm{n} \hat{O}=11)$ and D. lantosquensis $(2 \mathrm{n} \hat{O}=13)$ (Table S4). The $\mathrm{X}$ chromosome of D. garrafensis contained a conspicuous subterminal constriction at metaphase I (Fig. 16D). The X chromosomes of D. dolanskyi $\left(\mathrm{X}_{1} \mathrm{X}_{2} 0\right)$ were shorter than the single $\mathrm{X}$ chromosome of the other species, but the $\mathrm{X}_{1}$ chromosome of this species was still longer than the autosomes. The chromosome $\mathrm{X}_{2}$ was $\sim 2.5$ times shorter than $\mathrm{X}_{1}$ (Table $\mathrm{S} 4$ ). The $\mathrm{X}_{1}$ chromosome exhibited a subterminal constriction at some metaphase II plates (Fig. 16N).

Sex chromosomes exhibited a specific behaviour at male germinal cells. The single sex chromosome of the X0 system was positively heteropycnotic during premeiotic interphase. In contrast, this element did not differ by pycnosis from autosome bivalents during early prophase of the first meiotic division (leptotene-pachytene) (Fig. 16A). Following pachytene, autosome bivalents showed considerable despiralisation (so-called diffuse stage). In contrast to autosomes, the sex chromosome was highly condensed, forming a positively heteropycnotic body (Fig. 16B). Autosomes recondensed only during diakinesis. Condensation of bivalents was accompanied by a slight decondensation of the $\mathrm{X}$ chromosome (Fig. 16C). Bivalents usually only contained one chiasma; however, bivalents with two chiasmata were also observed (Fig. 16C). Bivalents showed precocious completion of chiasmata at metaphase I (Fig. 16E). The X chromosome exhibited standard meiotic segregation (Fig. 16F): its chromatids segregated at the anaphase of the second meiotic division (Fig. 16H). The X chromosome was positively heteropycnotic until prophase and metaphase II (Fig. 16G). In contrast to the autosomes, chromatids of the $\mathrm{X}$ chromosome were tightly attached until metaphase II (Fig. 16G).

The sex chromosomes of $D$. dolanskyi $\left(\mathrm{X}_{1} \mathrm{X}_{2} 0\right)$ displayed complex behaviour during male meiosis. While the $\mathrm{X}_{1}$ chromosome exhibited a similar pattern of heteropycnosis and chromatid association to the single $\mathrm{X}$ chromosome of the other species (Fig. 16I-N), the $\mathrm{X}_{2}$ chromosome was heteropycnotic only at the premeiotic interphase and the diffuse stage (Fig. 16I-K). At some interphase nuclei and early diffuse stages, $\mathrm{X}_{2}$ chromosomes consisted of two parts differing by intensity of heteropycnosis (Fig. 16J). Similarly to autosomes, chromatids of $\mathrm{X}_{2}$ chromosomes showed only loose association from metaphase and anaphase I onwards (Fig. 16L, M). The $\mathrm{X}$ chromosomes were associated at one end (premeiotic interphase, Fig. 16I; diffuse stage, Fig. 16K; anaphase I, Fig. 16M) or lay in parallel (some diffuse stages, Fig. 16J); however, their association appeared fragile and was often disrupted (especially at metaphase and anaphase I).

Remarkably, we found cells heterozygous for autosome fusion in the germline of some males. These plates were observed in three of four examined specimens of D. garrafensis $(\mathrm{S} 4,14,15)$ as well as one specimen each of $D$. corallina (CRBA VO000137), D. quindecima (CRBA VO000129) and D. fervida (S6). Individuals of $D$. garrafensis came from the same locality (La Pleta, Garraf National Park, Spain). The germline of a specimen of $D$. corallina was formed exclusively by heterozygous cells. In contrast to this, the gonads of the other specimens consisted of a mosaic of cells with standard and heterozygous genotypes. These specimens only showed a low frequency of heterozygous cells. During meiosis, heterozygous cells contained a trivalent formed by a fusion product, and two original unfused chromosomes. 


\section{Discussion}

The spider genus Dysdera is unique among dysderid genera and probably among other Palearctic spiders in the frequent occurrence of complexes of sibling species, often living in

5 sympatry. Here, we focussed on the D. erythrina-complex as a model system to gain a deeper understanding of the evolution of such lineages. We integrated information from different datasets to investigate species limits in the D. erythrina-complex, under the assumption that taxa differ mainly in features involved in the

10 speciation process. We distinguished 20 phenotypically similar taxa that fit the morphological species concept (Mallet 2007), which was further supported by karyotype and/or mitochondrial DNA (mtDNA) data (except for molecular data of D. kropfi, see below; Fig. 14).

15 The species of the D. erythrina-complex do not show conspicuous differences in habitat preference. In some Iberian sites, they even co-occur (e.g. D. catalonica, D. corallina, $D$. erythrina and D. garrafensis in the Garraf Massif; $D$. corallina and $D$. pradesensis in Poblet forest; in the

20 Pyrenees, D. minairo and D. pyrenaica are both found in the Cadi Massif and D. catalonica and D. fabrorum around the Ter River head). Up to five species have been found to cooccur along the upper part of the Tordera River, in the Montseny Massif (D. catalonica, D. corallina, D. septima, D. tredecima and

25 D. undecima). However, co-occurring species showed differences in morphological features (e.g. body size, genitalia; see Appendix 1), karyotypes (Table S4), and in most cases in mitochondrial DNA sequences.

\section{Structure and diversification of karyotypes}

30 Our data on karyotypes of the $D$. erythrina-complex are in agreement with previous studies on the genus Dysdera. Chromosomes of Dysdera are holokinetic and most species have a low chromosome number (Díaz and Sáez 1966; Benavente and Wettstein 1980; Král et al. 2006; Rezáč et al.

35 2007, 2014). The diploid number found in D. septima $(2 \mathrm{n} \hat{\delta}=7)$ is the lowest found in Dysdera so far. All Dysdera species previously karyotyped exhibit the X0 system (Rodríguez Gil et al. 2002; Král et al. 2006; Řezáć et al. 2007, 2014), which is probably the ancestral sex chromosome constitution of this

40 genus. The sex chromosome of Dysdera displays a specific behaviour during male meiosis, including positive heteropycnosis (i.e. higher intensity of staining), which reflects inactivation of this chromosome (Rodríguez Gil et al. 2002; Král et al. 2006). The single sex chromosome of $D$. crocata males

45 exhibits inverted meiosis (Rodríguez Gil et al. 2002; Král et al. 2006). This modification of meiotic segregation has been also described in other organisms with holokinetic chromosomes (Mola and Papeschi 2006). In contrast, the X chromosome of the D. ninnii-complex (Řezác et al. 2014) and the D. erythrina 50 complex (this study) possesses standard meiotic segregation.

In contrast to the other Dysdera species, $D$. dolanskyi shows the $\mathrm{X}_{1} \mathrm{X}_{2} \mathrm{O}$ system (this study). This sex chromosome determination is also found in other representatives of the superfamily Dysderoidea, namely, in the genus Segestria 55 (Segestriidae) (Suzuki 1954; Král et al. 2006). Although the $\mathrm{X}_{1} \mathrm{X}_{2} \mathrm{O}$ system is supposed to be ancestral in spiders (Suzuki 1954), it is derived from the X0 system in D. dolanskyi (this study) as suggested by the generalised occurrence of the $\mathrm{X} 0$ system in the remaining Dysdera species (Král et al. 2006; Řezáć et al. 2007, 2014; this study). The $\mathrm{X}_{2}$ chromosome of D. dolanskyi has evolved most likely as a result of fusion of a large fragment of $\mathrm{X}$ chromosome and an autosome fragment(s). Two lines of data support this scenario. First, the $\mathrm{X}_{1}$ chromosome of $D$. dolanskyi is shorter than the $\mathrm{X}$ chromosome of any other member of the D. erythrina-complex, which indicates formation of this element by considerable reduction of the $\mathrm{X}$ chromosome. Second, the $\mathrm{X}_{2}$ chromosome shows several autosome-like features during male meiosis. Association of $\mathrm{X}_{2}$ chromatids is completed in the same period as in autosomes. Furthermore, heteropycnosis of the $\mathrm{X}_{2}$ chromosome disappears much earlier than that of the $\mathrm{X}_{1}$ chromosome, which could be a consequence of integration of autosome material into $\mathrm{X}_{2}$. This idea is supported by the finding that a large part of the $\mathrm{X}_{2}$ chromosome shows lower intensity of heteropycnosis at some meiotic stages. This region could be derived from autosome material. Similar behaviour of autosomederived regions of sex chromosomes has been described, for example, in some salticids (Maddison 1982). Our data indicate that $\mathrm{X}$ chromosome evolution of the other lineages of the $D$. erythrina-complex has also included integration of autosome fragment(s) into the $\mathrm{X}$ chromosome (for summary see Fig. 17). Although supposed relatives of $D$. dolanskyi, $D$. erythrina and D. kropfi, exhibit similar reduction of X chromosome as $D$. dolanskyi, they retain an $\mathrm{X} 0$ system. This pattern could arise by an integration of the $\mathrm{X}$ chromosome fragment(s) into autosomes in a common ancestor of the latter two species (Table $\mathrm{S} 4$ ).

The D. erythrina-complex is remarkable in its considerable karyotype diversity. The confrontation of karyotype data with the mtDNA tree suggests that the ancestor of the complex exhibited a low diploid number $\left(2 \mathrm{n}^{\hat{\gamma}}=9\right)$ and a large $\mathrm{X}$ chromosome. Although species showing this karyotype belong to different lineages of the complex, they exhibit similar size of particular autosome pairs (Table S4). We hypothesise that the ancestral X chromosome size of the complex falls into the range of $22.7-24.1 \%$ of the total length of the haploid set. These X chromosome sizes are common in species of the complex (Fig. 17). The ancestral karyotype of the complex was probably close to the karyotype of $D$. pyrenaica. The first prominent autosome pair is a characteristic feature of this species, as it is considerably longer than the other autosome pairs. This pattern is retained even in some more derived species of the complex (Table S4).

\section{Role of chromosome rearrangements in the speciation process}

Chromosome rearrangement may have played a primary role in the generation of interspecific barriers in the genus Dysdera. In agreement with this hypothesis, sister species of the $D$. erythrina-complex differ by karyotype. These differences include number and/or length of both autosomes and sex chromosomes. Comparison of related species suggests that these karyotype differences reflect operation of chromosome fusions and fissions as well as translocation of fragments during evolution of the complex (Table S4; Fig. 17). In general, these rearrangements may be involved in formation of 


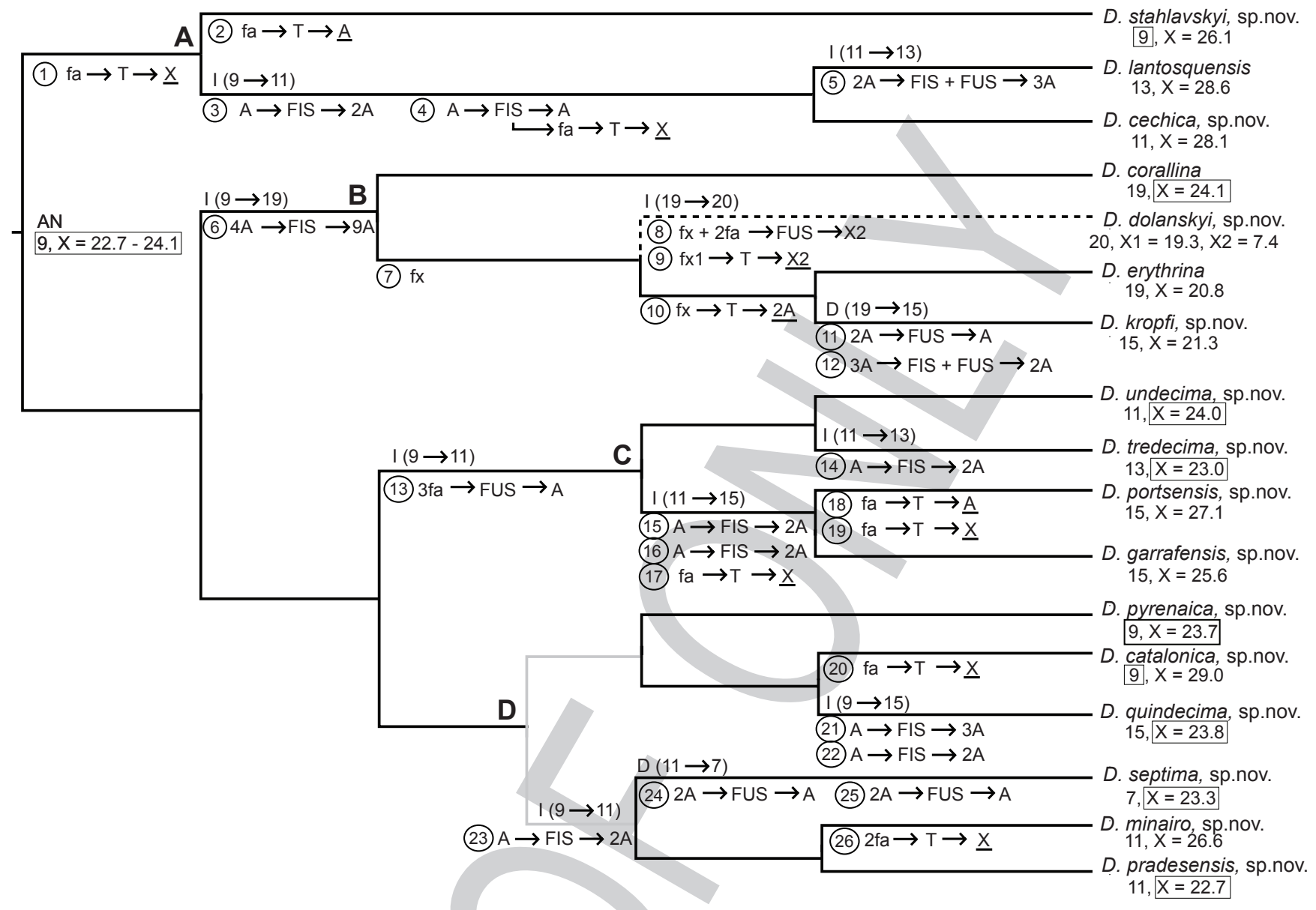

Fig. 17. Summary of hypotheses on karyotype evolution of the Dysdera erythrina-complex. The phylogeny used to map karyotype events is based on mitochondrial DNA (black branches) and cytogenetic information (grey branches, the data from mtDNA and karyotypes are contradictory; dashed branch, the data about mtDNA are missing). Each species is characterised by male $2 \mathrm{n}$ and the relative length of $\mathrm{X}$ chromosome(s) (at parentheses). The supposed ancestral pattern of these features is closed in boxes $(2 \mathrm{n} \hat{0}=9$, relative X chromosome length from 22.7 to $24.1 \%)$. Information above branches refers to decrease (D) or increase (I) of male $2 \mathrm{n}$ including specification of the change. Numbers under branches refer to particular karyotype events. See Table S4 for detailed information (numbering is the same; blue, event involving only autosomes; red, event including only sex chromosomes; green, event involving both autosomes and sex chromosomes). Events are specified by formula $\mathrm{A} \rightarrow \mathrm{R} \rightarrow \mathrm{B}$ or $\underline{\mathrm{B}}$ (A, element(s) involved in rearrangement; $\mathrm{R}$, type of rearrangement; $\mathrm{B}$, resulting element(s); $\underline{\mathrm{B}}$, acceptor of fragment(s)). A, autosome pair; AN, ancestral karyotype; f, fragment; fa, autosome fragment; fx, X chromosome fragment; FIS, fission; FIS + FUS, complex event including fission(s) and fusion(s); FU, fusion; $\mathrm{T}$, translocation; $\mathrm{X}, \mathrm{X}$ chromosome; $\mathrm{X}_{1}, \mathrm{X}_{1}$ chromosome; $\mathrm{X}_{2}, \mathrm{X}_{2}$ chromosome. Letters $\mathrm{A}, \mathrm{B}, \mathrm{C}$ and D above branches denominate the main clades, ancestral states of chromosome numbers and $\mathrm{X}$ chromosome lengths are highlighted in boxes.

interspecific barriers (King 1993). Fixation of these chromosome changes could be facilitated by holokinetic structure of chromosomes (Jacobs 2004). Frequent operation of fusions during the evolution of Dysdera is suggested by common 5 occurrence of fusion heterozygotes in populations of these spiders (Řezáč et al. 2014; this study). In our study, we detected not only standard heterozygotes but also individuals whose gonads were mosaics of standard cells and cells heterozygous for fusion. A population of $D$. garrafensis from

10 La Pleta (Garraf National Park, Spain) showed a high frequency of fusion mosaics, which suggests a frequent induction of fusions in this population, perhaps due to genotoxic stress. Indeed, environmental factors may increase the number of rearrangements, which can be fixed in the karyotype of a 15 species. Despite supposed stability of holokinetic fragments during divisions, there are no reliable findings of fission heterozygotes in populations of Dysdera, which could indicate the detrimental nature of fissions. Surprisingly, analysis of the $D$. erythrina-complex suggests that fissions may have predominated considerably over fusions during the evolution of this clade (Table S4; Fig. 17). Therefore, fissions may be less neutral and form more effective interspecific barriers than fusions in Dysdera. Fissions predominated during karyotype evolution in other organisms with holokinetic chromosomes, for example, in plants of the genus Carex (Cyperaceae) (Bureš et al. 2012). Besides this, considering the low frequency of recombinations in organisms with holokinetic chromosomes, the formation of extra chromosomes by fissions increases the frequency of crossing-over and thus the genetic diversity of populations (Bureš et al. 2012). Moreover, fissions increase the number of linkage groups, whose independent combination during meiosis increases the genetic variability of offspring more 
than through recombinations. Increases in genetic variability may facilitate the formation of adaptations. Fusions only took part in the evolution of some species of the D. erythrina-complex (Table S4; Fig. 17). Moreover, some of these events seem to be 5 complex, including not only fusions but also fissions (Table S4; Fig. 17). These complex changes may separate species more effectively than fusions alone.

The species $D$. undecima $(2 \mathrm{n} \hat{0}=11)$ and $D$. tredecima $(2 \mathrm{n} \hat{\jmath}=13)$ may provide a case of recent karyotype diversification. These forms are very similar from both a morphological and molecular perspective (species delimitation by molecular data did not even distinguished between them) and live in sympatry, but their karyotypes are probably already incompatible, as suggested by the reciprocal monophyly of 5 their mitochondrial haplotypes. Although these species show similar chromosome numbers, they differ in the length of some autosome pairs and X chromosome. Remarkably, the couples of closely related species that have the same $2 \mathrm{n}$ (D. corallina and D. erythrina, D. garrafensis and D. portsensis,

$20 D$. minairo and $D$. pradesensis) display the same pattern of karyotype differentiation. Karyotypes of the majority of these species arose presumably by translocations between the autosomes and sex chromosomes (Table S4; Fig. 17). Therefore, these karyotype changes could be frequent during 25 the early separation of the sister species of the complex. Rearrangements between autosomes and sex chromosomes can be very effective in the formation of reproductive barriers between species (King 1993).

The species $D$. kropfi proved to be an exception to the general 30 congruence observed between a specific karyotype and exclusive, monophyletic haplotypes. Despite considerable karyotype differences between $D$. erythrina and D. kropfi, the single sequence obtained fell within the variability of D. erythrina. A very recent karyotype change could explain 35 the incomplete lineage sorting observed among the mtDNA sequences. Sequencing of additional specimens of $D$. kropfi could confirm this hypothesis if they could be recovered as monophyletic. In addition, highly variable, nuclear markers (e.g. microsatellites, AFLP, SNPs) could be used to discard 40 ongoing gene flow among populations with different karyotypes. Similarly, incomplete lineage sorting of a single neutral marker could also explain the paraphyly (Funk and Omland 2003; Řezáč et al. 2016) recovered in the species D. lantosquensis and D. minairo (this study). Cytogenetic data of specimens exhibiting paraphyletic placement are not available.

\section{Geographic patterns of distribution and speciation}

Rapid divergence of karyotypes might have been facilitated by the inability of Dysdera to disperse over long distances, as suggested by the restricted distribution exhibited by most

50 species. Dysdera has never been observed to balloon (e.g. Duffey 1956; Blandenier and Fürst 1998), an airborne dispersal method used by the majority of spiders. Moreover, Dysdera spiders are closely associated with forest habitats (Deeleman-Reinhold and Deeleman 1988) (Fig. 18), which 55 were periodically fragmented during the Quarternary climatic oscillations (Iversen 1964). The low vagility combined with habitat fragmentation might have led to the formation of small, isolated populations in which chromosome rearrangements could have been easily fixed by genetic drift. Fixed chromosomal rearrangements effectively precluded hybridisation in secondarily overlapping populations following forest expansion during interglacials. Dysdera erythrina and D. kropfi constitute an example of entities that may have been isolated geographically and genetically by chromosome rearrangements, whereas their mtDNA sequences and morphology remain almost identical (see above).

Present-day distribution ranges of particular species of the complex (Fig. 13), in combination with phylogenetic information and the level of mtDNA variation provided by the DNA barcodes, hint at the key role of glacial cycles in shaping distributions of the $D$. erythrina-complex. Most species are partly or exclusively distributed in southern Europe. The southern European peninsulas have been long recognised as refugia for temperate species during glaciations, from which some species recolonised northern regions during postglacial periods (Taberlet et al. 1998; Hewitt and Ibrahim 2001). A strong reduction in genetic variation is the fingerprint of rapid postglacial colonisations (Hewitt 2004). The two Dysdera species with the most northern distributions (i.e. D. erythrina and D. cechica) show low levels of variation of mtDNA motifs (i.e. maximum intraspecific pair-wise divergence $0.3 \%$ ), although some of the specimens analysed for both species were collected more than $500 \mathrm{~km}$ apart. Conversely, species in the southernmost part of the distribution of the complex usually show higher level of this genetic diversity $(>1 \%)$ at much shorter distances (see Fig. 14). Future estimation analyses based on molecular clock methods on a better-supported, multilocus phylogeny of the D. erythrinacomplex will be required to confirm the hypothesised Quaternary timeframe of diversification.

\section{Evolution of recognition mechanisms}

The species of the D. erythrina-complex that occur in sympatry differ in karyotype and, with a single exception, exhibit exclusive, monophyletic haplotypes, which suggests that chromosomal rearrangements are an effective barrier to interspecific gene flow. Besides karyotype, sympatric species also exibit morphological differences, which are sometimes subtle but always consistent within species. For example, the copulatory organs, the shape of the chelicerae, and the sculpture of the carapace in D. erythrina are constant throughout a region that spans from England to Slovakia. This observation raises the question of why these closely related species consistently differ in these particular features. Sympatric coexistence of closely related species requires effective mechanisms for generating interspecific barriers and reducing competition for prey (Otte and Endler 1989). We hypothesise that the observed differences between the species reflect the action of such mechanisms.

Secondary contact of divergent species likely led to selection for recognition mechanisms that would prevent these species from wasting their reproduction potential (reinforcement, sensu Rundle and Nosil 2005). These mechanisms might have led to a one-sided precopulatory barrier between D. erythrina and D. cechica, as was found in the present study. Species recognition in Dysdera is probably based on sexual pheromones. However,

\section{5}




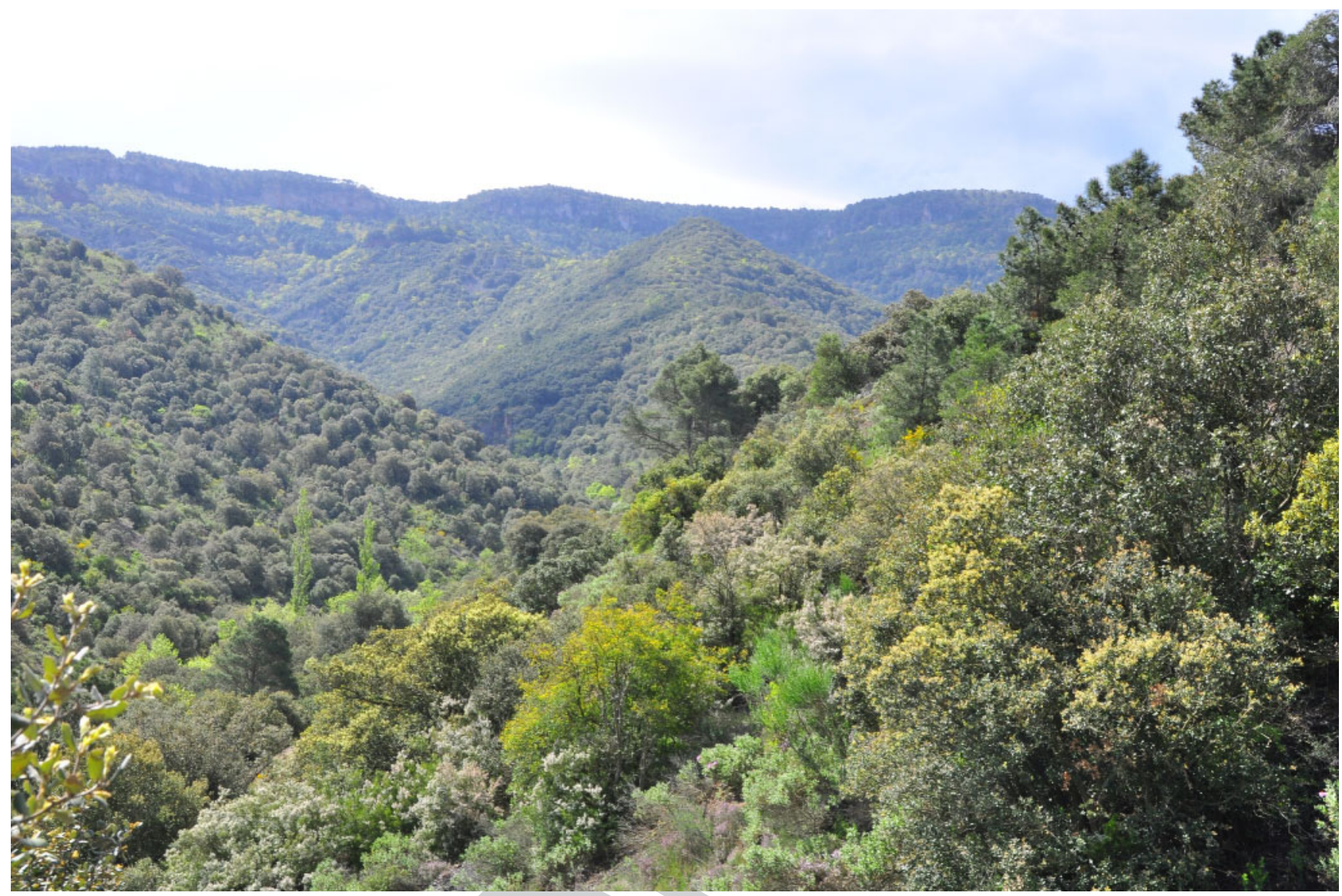

Fig. 18. Oak forest, Montseny Mts, NE Spain. This habitat harbours at least six species of the Dysdera erythrina-complex.

there is no information about these molecules in dysderids. Nonetheless, interspecific copulations have been observed in some species of Dysdera (Cooke 1965a). In this study, we observed copulation between males of $D$. cechica and females 5 of D. erythrina, two species whose karyotypes differ considerably. Therefore, offspring produced by hybridisation of these species may be expected to be mostly or completely non-viable or sterile. Hybridisation of sympatric species could be restricted by separation of their reproductive periods (e.g. Friesen

10 et al. 2007). Indeed, we found that some species differ in the timing of spermatogenesis (Table S3), which could reflect this kind of separation.

Surprisingly, the only evidence for interspecific gene flow in our molecular data comes from $D$. corallina and D. catalonica, two 15 species that exhibit deep molecular (average p-distance $=12 \%$ ) and karyotype divergence. Although a specimen of $D$. corallina exhibiting mitochondrial sequences of $D$. catalonica came from the locality populated by both of these species, it shows the standard karyotype of $D$. corallina, which precludes a hybrid 20 origin. Therefore, unusual mtDNA of this specimen could be a consequence of introgression (in spiders documented, e.g. in Eresus; Rezáč et al. 2008a). More molecular data including information about nuclear genes are necessary to prove introgression of genetic material of $D$. catalonica into the genome of $D$. corallina. Alternatively, this result could reflect specimen mishandling or mislabelling.

\section{Prey segregation}

The results of our experiments revealed that all tested species readily capture woodlice. Interestingly, we found remarkable interspecific differences in body size and morphology of mouthparts (particularly chelicerae) in the D. erythrinacomplex, which may be indicative of specialisation on different sizes of woodlice. In this context, it is remarkable that woodlice species show extraordinary polymorphism in size, due to their epimeric ontogeny (Sutton 1980), providing a range of sizes that may be exploited by several specialised woodlice predators. Particular Dysdera species may have started to specialise on specific woodlice during the initial, allopatric stage of speciation, when food resources were more restricted in a small area. Natural selection would have reinforced specialisation in secondarily sympatric species by favouring prey segregation and thus niche partitioning. The comparison of the morphology of closely related species living in sympatry provides insights into the role of prey segregation in promoting species co-existence. For example, D. catalonica, D. septima and D. undecima, which live in sympatry in the Monsteny Massif, 
Table 1. The aspects that are different in the Dysdera erythrina-complex (this study) and the $D$. ninnii-complex (Řezáč et al. 2014)

\begin{tabular}{lllll}
\hline Complex & Genetic markers & Karyotype & Morphology & Distribution \\
\hline D. ninnii & Pattern of rare introgression & $\begin{array}{c}\text { The same chromosome } \\
\text { numbers }\end{array}$ & $\begin{array}{c}\text { The same body size and cheliceral } \\
\text { shape; only copulatory organs differ }\end{array}$ & Allopatric or parapatric \\
D. erythrina & Well-defined discrete species & $\begin{array}{c}\text { Often different chromosome } \\
\text { numbers }\end{array}$ & $\begin{array}{c}\text { Different copulatory organs; } \\
\text { diversified body size, some species } \\
\text { differ in cheliceral shape }\end{array}$ & Allopatric or often sympatric \\
\hline
\end{tabular}

differ in size, but not in cheliceral morphology, suggesting specialisation on different sizes of woodlice (possible case of character displacement, unknown so far in spiders; Agnarsson et al. 2016).

$5 \quad$ The clade formed by species $D$. cechica and $D$. lantosquensis provides the most obvious case of cheliceral modification. The chelicerae of these species have a markedly concave frontal side. The different modifications of chelicerae are shown to correlate with different tactics of grasping armoured woodlice (Řezáč et al.

10 2008b). Dysdera cechica and D. lantosquensis most often tuck the chelicerae under a woodlouse and insert the fangs into the soft ventral side (i.e. 'fork' tactic). In contrast, the other species, with straight chelicerae, most often turn the prosoma sideways, enabling the spider to insert one chelicera underneath the 15 woodlouse and the other over the dorsal side of the woodlouse (i.e. 'pincers' tactic). The fork tactic allows capture of larger prey than the pincers tactic, because the latter is limited by the size of the woodlouse, which has to be small enough to fit between the chelicerae. From this perspective, the species $D$. cechica 20 and D. lantosquensis are morphologically more specialised on oniscophagy than the other studied species.

\section{Uncovered diversity}

Our molecular data suggest that the number of potential species in the D. erythrina-complex may be even larger than the actual 25 species described in the present study. Evolutionary species delimitation methods using mtDNA data agreed in splitting some of the nominal species further into genetically divergent lineages (e.g. D. catalonica, D. corallina). Deep coalescence in mitochondrial genes, however, is not necessarily indicative of

30 species status (e.g. Hamilton et al. 2016). Karyotyped specimens of these species do not differ by chromosome features. Therefore, considerable molecular differences among populations may just reflect reduced dispersal capabilities or complex demographic changes and, in some cases, it may be just the product of random

35 processes (Irwin 2002). The incorporation of additional sources of evidence is essential to uncover the evolutionary significance (i.e. grant species status) of divergent mitochondrial lineages, in an integrative taxonomy framework (see Stockman and Bond 2007; Bond and Stockman 2008). The lack of additional

40 specimens for morphological and karyotype studies prevented us from proposing any further species. Formal description of additional species will have to await new collections of specimens that provide consistent diagnostic features across different datasets.

\section{Conclusions}

Sympatric occurrence of close relatives has been documented in several Dysdera species complexes. Interestingly, the species of these complexes differ in similar features, namely, karyotype, body size and shape of the chelicerae (e.g. Deeleman-Reinhold and Deeleman 1988; Arnedo and Ribera 1999; Řezáč et al. 2007). Here, we focussed on one of these species complexes, the $D$. erythrina-complex, but the evolutionary inferences made based on the integration of multiple datasets can be expanded to explain the origins of other Dysdera species complexes. Thus far, the best-researched complex is the $D$. ninnii-complex (Řezác et al. 2014). The comparison of this complex with the D. erythrina-complex further elucidates speciation in the genus Dysdera (Table 1). In general, the species of the D. ninniicomplex seem to be in an earlier stage of the speciation process. Their karyotypes are still composed of the same number of chromosomes, making hybridisation more probable. Indeed, we found evidence for rare introgression in these species. In contrast to some species of the D. erythrina-complex, they do not differ in features related to the division of food resources, in particular, body size and chelicerae shape. Indeed, parapatric distribution of some species indicates competition for prey and an unfinished interspecific barrier.

In summary, we propose that the main driver of speciation in Dysdera complexes is the genetic barriers generated by chromosome rearrangements, which may have evolved in allopatry and been fixed through genetic drift, probably as a result of habitat fragmentation during glacial cycles (speciation by genetic drift sensu Schluter 2001). Subsequently, ecophenotypical differentiation driven by natural selection may have promoted sympatric coexistence through secondary contact. The suggested speciation mode predicts the existence of geographically isolated, cryptic species possessing a specific karyotype but not morphological differences, and deep genealogy breaks associated with quaternary glaciations. Testing of the proposed evolutionary scenario will require gathering of additional data from nuclear genes of the studied species to further assess their genetic isolation, infer phylogenetic relationships and estimate time of diversification.

\section{Acknowledgements}

We thank F. Gasparo (Trieste, Italy), P. Kment (Národní muzeum, Prague, Czechia), J. C. Ledoux (France), S. Pekár (Masaryk University, Brno, Czechia), M. Harvey (Western Australian Museum, Welshpool, Australia), W. Fannes (Royal Museum for Central Africa, Tervuren, Belgium), F. M. Labarque (Instituto Butantan, São Paulo, Brasil), M. Kuntner (Research Centre of the Slovenian Academy of Sciences and Arts, Ljubljana, Slovenia) and I. Agnarsson (University of Vermont, Burlington, USA) for comments on the manuscript, M. Strickland (University of Nottingham, UK) for linguistic corrections of the manuscript, C. Hervé (National Museum of Natural History, Paris, France) for providing some inaccessible literature and material, M. Forman (Charles University in Prague, Czechia) for assistance with figures, and the following colleagues who 
provided us with the material: J. Beccaloni (British Museum of Natural History, London, Great Britain), R. Bosmans (Laboratorium voor Ecologie, Gent, Belgium), S. Danflous (Conservatoire d'Espaces Naturels de Midi-Pyrénées, Toulouse, France), E. De Mas (University of Barcelona,

5 Barcelona, Spain), S. Déjean (Conservatoire d'Espaces Naturels de MidiPyrénées, Toulouse, France), J. Dolanský (Eastern Bohemian Museum, Pardubice, Czechia), J. Dunlop (Museum of Natural History, Humboldt University, Berlin, Germany), F. Gasparo (Trieste, Italy), J. Gruber (Naturhistorisches Museum, Wien, Austria), A. Hänggi (Naturhistorisches

10 Museum, Basel, Switzerland), T. Kronestedt (Museum of Natural History, Stockholm, Sweden), C. Kropf (Naturhistorisches Museum der Burgergemeinde, Bern, Switzerland), J. C. Ledoux (Solignac sur Loire, France), B. Leroy (Paris, France), E. Líznarová (Masaryk University, Brno, Czechia), G. Milledge (Australian Museum, Sydney, Australia),

15 S. Nawai (Museum of Natural History, Humboldt University, Berlin, Germany), C. Rollard (National Museum of Natural History, Paris, France), L. Sentenská (Masaryk University, Brno, Czechia), F. Št áhlavský (Charles University, Prague, Czechia), T. Szüts (Western Hungarian University, Sopron, Hungary) and S. Vinkler (Brno, Czechia). Milan

20 Řezáč was supported by the Czech Ministry of Agriculture (MZe RO0415); J. Král and J. Musilová were supported by the project of the Grant Agency of the Academy of Sciences of the Czech Republic (IAA601110808); V. Řezáčová was supported by the long-term development program RVO61388971; M. Arnedo was funded by the grant

25 CGL2006-08617 of the Spanish Ministry of Science and Innovation (MICINN), and furthermore by an ICREA Academia award for excellence in research from Generalitat de Catalunya (Spain); V. Opatova was supported by Czech Ministry of Education, Youth and Sports and European Union Erasmus program 2006/2007.

\section{References}

Agnarsson, I., Gotelli, N. J., Agostini, D., and Kuntner, M. (2016). Limited role of character displacement in the coexistence of congeneric Anelosimus spiders in a Madagascan montane forest. Ecography 39, 743-753. doi:10.1111/ecog.01930

35 Alicata, P. (1964). Le specie Italiane di Harpactocrates e di Parachtes n. gen. (Araneae, Dysderidae). Annuario dell'Instituto e Museo di Zoologia dell'Università di Napoli 16, 1-40.

Araújo, D., Rheims, C. A., Brescovit, A. D., and Cella, D. M. (2008). Extreme degree of chromosome number variability in species of the spider genus Scytodes (Araneae, Haplogynae, Scytodidae). Journal of Zoological Systematics and Evolutionary Research 46, 89-95. doi:10.1111/j.14390469.2007.00457.x

Arnedo, M. A., and Ribera, C. (1999). Radiation of the genus Dysdera (Araneae, Dysderidae) in the Canary Islands: the island of Tenerife. The Journal of Arachnology 27, 604-662.

Arnedo, M. A., Oromí, P., and Ribera, C. (2000). Systematics of the genus Dysdera (Araneae, Dysderidae) in the eastern Canary Islands. The Journal of Arachnology 28, 261-292. doi:10.1636/0161-8202(2000)028[0261: SOTGDA]2.0.CO;2

50 Arnedo, M. A., Oromí, P., and Ribera, C. (2001). Radiation of the spider genus Dysdera (Araneae, Dysderidae) in the Canary Islands: cladistic assessment based on multiple data sets. Cladistics 17, 313-353. doi:10.1111/j.1096-0031.2001.tb00129.x

Arnedo, M. A., Oromí, P., Múrria, C., Macías-Hernández, N. E., and Ribera, C. (2007). The dark side of an island radiation: systematics and evolution of troglobitic spiders of the genus Dysdera (Araneae, Dysderidae) in the Canary Islands. Invertebrate Systematics 21, 623-660. doi:10.1071/ IS07015

Arnedo, M. A., Gasparo, F., and Opatová, V. (2009). Systematics and phylogeography of the Dysdera erythrina species complex (Araneae, Dysderidae) in Sardinia. ZooKeys 16, 319-345. doi:10.3897/zookeys. 16.128
Audouin, V. (1826). Explication sommaire des planches d'arachnides de l'Egypte et de la Syrie. Histoire et Nature 1, 99-186.

Becker, L. (1896). Les arachnides de Belgique. Annales du Musée royal d' histoire naturelle de Belgique 12, 1-378.

Bellmann, H. (2001). 'Kosmos-Atlas Spinnentiere Europas.' (Kosmos Verlag: Stuttgart, Germany.)

Benavente, R., and Wettstein, R. (1980). Ultrastructural characterization of the sex chromosomes during spermatogenesis of spiders having holocentric chromosomes and long diffuse stage. Chromosoma 77, 69-81. doi:10.1007/BF00292042

Berland, L. (1912). Observations sur l'accouplement des araignées. Archives de Zoologie Expérimentale et Générale. Notes et Revue 9, 47-52.

Bidegaray-Batista, L., Macías-Hernández, N., Oromí, P., and Arnedo, M. A. (2007). Living on the edge: demographic and phylogeographical patterns in the woodlouse-hunter spider Dysdera lancerotensis Simon, 1907 on the eastern volcanic ridge of the Canary Islands. Molecular Ecology 16, 3198-3214. doi:10.1111/j.1365-294X.2007.03351.x

Blackwall, J. (1864). 'A History of the Spiders of Great Britain and Ireland.' (Ray Society: London.)

Blandenier, G., and Fürst, P. A. (1998). Ballooning spiders caught by a suction trap in an agricultural landscape in Switzerland. In 'Proceedings of the 17th European Colloquium of Arachnology, 1997, Edinburgh'. (Ed. P. Selden.) pp. 177-186. (British Arachnological Society: Bucks, Burnham Beeches, UK.)

Bond, J. E., and Stockman, A. K. (2008). An integrative method for delimiting cohesion species: finding the population-species interface in a group of Californian trapdoor spiders with extreme genetic divergence and geographic structuring. Systematic Biology 57, 628-646. doi:10.1080/ 10635150802302443

Bösenberg, W. (1902). Die Spinnen Deutschlands. II-IV. Zoologica (Stuttgart) 14, 97-384. [see Pl. IX-XXXVI]

Bristowe, W. S. (1958). 'The World of Spiders.' (Collins: London.)

British Arachnological Society (2015). Dysdera erythrina. In 'Spider Recording Scheme. Website and On-line Database Facility'. Available at http://srs.britishspiders.org.uk/portal.php/p/Summary/s/Dysdera+ery thrina [20 November 2016].

Britton, T., Anderson, C. L., Jacquet, D., Lundqvist, S., and Bremer, K. (2007). Estimating divergence times in large phylogenetic trees. Systematic Biology 56, 741-752. doi:10.1080/10635150701613783

Buchar, J., and Rúžička, V. (2002). 'Catalogue of Spiders of the Czech Republic.' (Peres: Prague.)

Bureš, P., Zedek, F., and Marková, M. (2012). Holocentric chromosomes. In 'Plant Genome Diversity. Vol. 2: Physical Structure, Behaviour and Evolution of Plant Genomes'. (Eds I. J. Leitch, J. Greilhuber, J. Doležel and J. F. Wendel.) pp. 187-208. (Springer Verlag: Heidelberg and Berlin, Germany.)

Burger, M. (2011). Functional morphology of female goblin spider genitalia (Arachnida: Araneae: Oonopidae) with notes on fertilization in spiders. Zoologischer Anzeiger 250, 123-133. doi:10.1016/j.jcz.2010.12.003

Charitonov, D. E. (1956). Overview of spiders of the family Dysderidae of the USSR. Uchenie Zapiski Molotovskogo Gosudarstvennogo Universiteta 10, 17-39. [In Russian]

Chytrý, M., Kučera, T., and Kočí, M. (Eds) (2001). 'Catalogue of Biotopes of the Czech Republic.' (Agency for Nature Conservation and Landscape Protection of the Czech Republic: Prague.) [In Czech]

Chyzer, C., and Kulczyński, W. (1897). Araneae Hungariae. Tomus II. Academia Scientiarum Hungaricae, Budapest. pp. 147-366, P1. VI-X.

Clement, M., Posada, D., and Crandall, K. A. (2000). TCS: a computer program to estimate gene genealogies. Molecular Ecology 9, 1657-1659. doi:10.1046/j.1365-294x.2000.01020.x

Cooke, J. A. L. (1965a). A contribution to the biology of the British spiders belonging to the genus Dysdera. Oikos 16, 20-25. doi:10.2307/3564861

Cooke, J. A. L. (1965b). Beobachtungen an der Spinnengattung Dysdera. Natur und Museum 95, 179-184. 
Cooke, J. A. L. (1965c). Spider genus Dysdera (Araneae, Dysderidae). Nature 205, 1027-1028. doi:10.1038/2051027b0

Cooke, J. A. L. (1966). Synopsis of the structure and function of the genitalia in Dysdera crocata (Araneae, Dysderidae). Senckenbergiana Biologica 47, 35-43.

Deeleman-Reinhold, C. L., and Deeleman, P. R. (1988). Révision des Dysderinae (Araneae, Dysderidae), les espèces mediterraneennes occidentales exceptees. Tijdschrift voor Entomologie 131, 141-269.

Deltshev, C. C., C určić, B. P. M., and Blagoev, G. A. (2003). 'The Spiders of Serbia.' (Commitee for Karst and Speleology, Serbian Academy of Sciences and Arts; Institute of Zoology, Bulgarian Academy of Sciences: Belgrade, Sofia.)

Díaz, M., and Sáez, F. A. (1966). Investigaciones citogenéticas sobre algunas especies de araneidos uruguayos. In 'Anales (II) Congreso Latinoamericano de Zoología'. pp. 3-9. (San Pablo: Brazil.)

Dobigny, G., Aniskin, V., Granjon, L., Cornette, R., and Volobouev, V. (2005). Recent radiation in West African Taterillus (Rodentia, Gerbillinae): the concerted role of chromosome and climatic changes. Heredity 95, 358-368. doi:10.1038/sj.hdy.6800730

20 Drensky, P. (1938). Die Spinnenfauna Bulgariens. II. Unterordnung arachnomorphae, I gruppe Tetrastica, familien: Filistatidae, Dysderidae und Oonopidae. Mitteilungen aus den Königlichen Naturwissenschaftlichen Instituten in Sofia 11, 81-106.

Dresco, E. (1973). Araignées de Bretagne. Le genre Dysdera (fam. Dysderidae). Bulletin de la Société Scientifique de Bretagne 47, 245-256.

Drummond, A. J., Ashton, B., Cheung, M., Heled, J., Kearse, M., Moir, R., Stones-Havas, S., Thierer, T., and Wilson, A. (2009). Geneious v. 4.7. Available at http://www.geneious.com [accessed 11 August 2011].

Drummond, A. J., Suchard, M. A., Xie, D., and Rambaut, A. (2012). Bayesian phylogenet cs with BEAUti and the BEAST 1.7. Molecular Biology and Evolution 29, 1969-1973. doi:10.1093/molbev/mss075

Duffey, E. (1956). Aerial dispersion in a known spider population. Journal of Animal Ecology 25, 85-111. doi:10.2307/1852

Dufour, L. (1820). Observations sur quelques arachnides quadripulmonaires. Annales Générales des Sciences Physiques 5, 96-116.

Eberhard, W. G. (1985). 'Sexual Selection and Animal Genitalia.' (Harvard University Press: Cambridge and London.)

Fage, L. (1913). Etudes sur les Araignées cavernicoles. II. Revision des Leptonetidae. Biospelogica, XXIX. Archives de Zoologie Expérimentale et Générale 10, 479-576.

Folmer, O., Black, M., Hoeh, W., Lutz, R., and Vrijenhoek, R. (1994). DNA primers for amplification of mitochondrial cytochrome $\mathrm{c}$ oxidase subunit $\mathrm{i}$ from diverse metazoan invertebrates. Molecular Marine Biology and Biotechnology 3, 294-299.

45 Forster, R. R., and Platnick, N. I. (1985). A review of the austral spider family Orsolobidae (Arachnida, Araneae), with notes on the superfamily Dysderoidea. Bulletin of the American Museum of Natural History 181, 212-229.

Friesen, V. L., Smith, A. L., Gómez-Díaz, E., Bolton, M., Furness, R. W., González-Solís,, J., and Monteiro, L. R. (2007). Sympatric speciation by allochrony in a seabird. Proceedings of the National Academy of Sciences of the United States of America 104, 18589-18594. doi:10.1073/ pnas. 0700446104

Fujisawa, T., and Barraclough, T. G. (2013). Delimiting species using singlelocus data and the generalized mixed Yule coalescent approach: a revised method and evaluation on simulated data sets. Systematic Biology 62 , 707-724. doi:10.1093/sysbio/syt033

Funk, D. J., and Omland, K. E. (2003). Species-level paraphyly and polyphyly: frequency, causes, and consequences, with insights from animal mitochondrial DNA. Annual Review of Ecology Evolution and Systematics 34, 397-423. doi:10.1146/annurev.ecolsys.34.011802.132421

Gajdoš, P., Svatoň, J., and Sloboda, K. (1999). 'Catalogue of Slovakian Spiders.' (Institute of Landscape Ecology, Slovak Academy of Sciences: Bratislava, Slovakia.)
Hahn, C. W. (1831). Die Arachniden. Erster Band, Nürnberg, Germany. pp. 1-24.

Hamilton, C. A., Hendrixon, B. E., and Bond, J. E. (2016). Taxonomic revision of the tarantula genus Aphonopelma Pocock, 1901 (Araneae, Mygalomorphae, Theraphosidae) within the United States. ZooKeys 560, 18-25. doi:10.3897/zookeys.560.6264

Hart, M. W., and Sunday, J. (2007). Things fall apart: biological species form unconnected parsimony networks. Biology Letters 3, 509-512. doi:10.1098/rsbl.2007.0307

Heimer, S., and Nentwig, W. (1991). 'Spinnen Mitteleuropas.' (Verlag Paul Parey: Hamburg, Germany.)

Hewitt, G. (2004). Genetic consequences of climatic oscillations in the quaternary. Philosophical Transactions of the Royal Society of London. Series B, Biological Sciences 359, 183-195. doi:10.1098/ rstb.2003.1388

Hewitt, G., and Ibrahim, K. (2001). 'Inferring Glacial Refugia and Historical Migrations with Molecular Phylogenies.' (Blackwell: Oxford.)

Hopkin, S. P., and Martin, M. H. (1985). Assimilation of zinc, cadmium, lead, copper, and iron by the spider Dysdera crocata, a predator of woodlice. Bulletin of Environmental Contamination and Toxicology 34, 183-187. doi:10.1007/BF01609722

Irwin, D. E. (2002). Phylogeographic breaks without geographic barriers to gene flow. Evolution 56, 2383-2394. doi:10.1111/j.0014-3820.2002. tb00164.x

Iversen, J. (1964). Retrogressive vegetational succession in the post-glacial. Journal of Ecology 52, 59-70.

Jacobs, D. H. (2004). The evolution of a neo- $\mathrm{XY}_{1} \mathrm{Y}_{2}$ sex chromosome system by autosome-sex chromosome fusion in Dundocoris nodulicarinus Jacobs (Heteroptera: Aradidae: Carventinae). Chromosome Research 12, 175-191. doi:10.1023/B:CHRO.0000013155.99614.57

Jiggins, C. S., and Mallet, J. (2000). Bimodal hybrid zones and speciation. Trends in Ecology \& Evolution 15, 250-255. doi:10.1016/S0169-5347 (00)01873-5

King, M. (1993). 'Species Evolution: the Role of Chromosome Change.' (Cambridge University Press: Cambridge, UK.)

Koch, C. L. (1838). Die Arachniden. Vierter Band, pp. 109-144, Fünfter Band, pp. 1-124, Nürnberg, Germany.

Král, J., Musilová, J., Št áhlavský, F., Řezáč, M., Akan, Z., Edwards, R. L., Coyle, F. A., and Ribera, C. (2006). Evolution of the karyotype and sex chromosome systems in basal clades of araneomorph spiders (Araneae: Araneomorphae). Chromosome Research 14, 859-880. doi:10.1007/ s10577-006-1095-9

Lanfear, R., Calcott, B., Ho, S. Y. W., and Guindon, S. (2012). PartitionFinder: combined selection of partitioning schemes and substitution models for phylogenetic analyses. Molecular Biology and Evolution 29, 1695-1701. doi:10.1093/molbev/mss020

Latreille, P. A. (1804). Tableau methodique des insectes. Nouveau Dictionnaire d' Histoire Naturelle, Paris 24, 129-295.

Locket, G. H., and Millidge, A. F. (1951). 'British Spiders. I.' (Ray Society: London.)

Loksa, I. (1969). Araneae I. Fauna Hungariae 97, 1-133.

Macgregor, H. C. (1993). 'An Introduction into Animal Cytogenetics.' (Chapman \& Hall: London.)

Macías-Hernández, N., Oromí, P., and Arnedo, M. A. (2008). Patterns of diversification on old volcanic islands as revealed by the woodlouse-hunter spider genus Dysdera (Araneae, Dysderidae) in the eastern Canary Islands. Biological Journal of the Linnean Society. Linnean Society of London 94, 589-615. doi:10.1111/j.1095-8312. 2008.01007.x

Maddison, W. P. (1982). XXXY sex chromosomes in males of the jumping spider genus Pellenes (Araneae: Salticidae). Chromosoma (Berlin) 85, 23-37. doi:10.1007/BF00344592

Mallet, J. (2007). Species, concepts of. In 'Encyclopedia of Biodiversity'. (Ed. S. A. Levin.) pp. 1-15. (Elsevier: Oxford, UK.) 
Mcheidze, T. S. (1997). 'Spiders of Georgia: Systematics, Ecology, Zoogeographic Review.' (Tbilisi University: Tbilisi, Georgia.) [In Georgian]

Meier, R., Shiyang, K., Vaidya, G., and Ng, P. K. L. (2006). DNA barcoding and taxonomy in Diptera: a tale of high intraspecific variability and low identification success. Systematic Biology 55, 715-728. doi:10.1080/ 10635150600969864

Miller, F. (1971). Order Spiders - Araneida. In 'Key to the Fauna of Czechoslovakia. IV'. (Eds M. Daniel and V. Černý.) pp. 51-306. (Czechoslovak Academy of Sciences: Prague.) [In Czech]

Mola, L. M., and Papeschi, A. G. (2006). Holokinetic chromosomes at a glance. Journal of Basic \& Applied Genetics 16, 1-4.

Monaghan, M. T., Wild, R., Elliot, M., Fujisawa, T., Balke, M., Inward, D. J. G., Lees, D. C., Ranaivosolo, R., Eggleton, P., Barraclough, T. G., and Vogler, A. P. (2009). Accelerated species inventory on Madagascar using coalescent-based models of species delineation. Systematic Biology 58, 298-311. doi:10.1093/sysbio/syp027

Muller, L. (1967). Les haplogynes dans le Grand-Duché de Luxembourg. Archives de l'Institut Grand-Ducal de Luxembourg 32, 117-127.

20 Nedvěd, O., Pekár, S., Bezděčka, P., Líznarová, E., Řezáč, M., Schmitt, M., and Sentenská, L. (2011). Ecology of Arachnida alien to Europe. BioControl 56, 539-550. doi:10.1007/s10526-011-9385-3

Nentwig, W. (1987). The diet of spiders. In 'Ecophysiology of Spiders'. (Ed. W. Nentwig.) pp. 250-263. (Springer Verlag: Heidelberg and Berlin, Germany.)

Otte, D., and Endler, J. A. (Eds) (1989). 'Speciation and its Consequences.' (Sinauer: Sunderland, MA.)

Pekár, S., Líznarová, E., and Řezáč, M. (2016). Suitability of woodlice prey for generalist and specialist spider predators: a comparative study. Ecological Entomology 41, 123-130. doi:10.1111/een.12285

Pollard, S. D., Jackson, R. R., van Olphen, A., and Robertson, M. V. (1995). Does Dysdera crocata (Araneae Dysderidae) prefer woodlice as prey? Ethology Ecology and Evolution 7, 271-275. doi:10.1080/08927014. 1995.9522957

35 Pons, J., Barraclough, T. G., Gomez-Zurita, J., Cardoso, A., Duran, D. P., Hazell, S., Kamoun, S., Sumlim, W. D., and Vogler, A. P. (2006). Sequence-based species delimitation for the DNA taxonomy of undescribed insects. Systematic Biology 55, 595-609. doi:10.1080/ 10635150600852011

40 Qumsiyeh, M. B. (1994). Evolution of number and morphology of mammalian chromosomes. The Journal of Heredity 85, 455-465. doi:10.1093/oxfordjournals.jhered.a111501

Raupach, M. J. (2005). Die Bedeutung von Landasseln als Beutetiere für Insekten und andere Arthropoden. Entomologie Heute 17, 3-12.

45 Řezáč, M. (2012). Distribution of the six-eyed spiders of the genus Dysdera (Araneae: Dysderidae) in Czechia. Přriroda 30, 117-162. [In Czech]

Řezáč, M., and Pekár, S. (2007). Evidence for woodlice-specialization in Dysdera spiders: behavioural versus developmental approaches. Physiological Entomology 32, 367-371. doi:10.1111/j.1365-3032.2007. 00588.x

Řezáč, M., Král, J., Musilová, J., and Pekár, S. (2006). Unusual karyotype diversity in the European spiders of the genus Atypus (Araneae: Atypidae). Hereditas 143, 123-129. doi:10.1111/j.2006.0018-0661.01949.x

55 Řezáč, M., Král, J., and Pekár, S. (2007). The spider genus Dysdera (Araneae, Dysderidae) in central Europe: revision and natural history. The Journal of Arachnology 35, 432-462. doi:10.1636/H06-38.1

Řezáč, M., Pekár, S., and Johannesen, J. (2008a). Taxonomic review and phylogenetic analysis of central European Eresus species (Araneae: Eresidae). Zoologica Scripta 37, 263-287. doi:10.1111/j.14636409.2008.00328.x

Řezáč, M., Pekár, S., and Lubin, Y. (2008b). How oniscophagous spiders overcome woodlouse armour. Journal of Zoology 275, 64-71. doi:10.1111/j.1469-7998.2007.00408.x
Řezác, M., Gasparo, F., Král, J., and Heneberg, P. (2014). Integrative taxonomy and evolutionary history of a newly revealed Dysdera ninnii complex (Araneae: Dysderidae). Zoological Journal of the Linnean Society 172, 451-474. doi:10.1111/zoj.12177

Řezáč, M., Řezáčová, V., and Heneberg, P. (2016). Enoplognatha bryjai new species, a bizzare cobweb spider of the Pannonian swamps (Araneae, Theridiidae). Zootaxa 4147, 92-96. doi:10.11646/zootaxa.4147.1.8

Ribera, C., Ferrández, M. A., and Pérez, J. A. (1986). Los Dysderidae (Arachnida, Araneae) cavernicolas de la Peninsula Iberica. In 'Proceedings of the Ninth International Congress of Arachnology, Panama 1983'. (Ed. W. G. Eberhard.) pp. 241-244. (Smithsonian Institution Press: Washington, DC.)

Rieseberg, L. H. (2001). Chromosomal rearrangements and speciation. Trends in Ecology \& Evolution 16, 351-358. doi:10.1016/S0169-5347 (01)02187-5

Risso, A. (1826). Les Arachnides. In 'Histoire Naturelle des Principales Productions de l'Europe Méridionale, et Principalement de Celles des Environs de Nice et des Alpes Maritimes. Vol. 5'. pp. 159-176. (F. G. Levrault: Paris.)

Roberts, M. J. (1985). 'The Spiders of Great Britain and Ireland. Vol. 1: Atypidae to Theridiosomatidae.' (Harley Books: Colchester, UK.)

Roberts, M. J. (1995). 'Spiders of Britain and Northern Europe.' (Harper Collins Publishers: London.)

Roberts, M. J. (1998). 'Spinnengids.' (Tirion: Baarn, the Netherlands.)

Rodríguez Gil, S. G., Mola, L. M., Papeschi, A. G., and Scioscia, C. L. (2002). Cytogenetic heterogeneity in common haplogyne spiders from Argentina (Arachnida, Araneae). The Journal of Arachnology 30, 47-56. doi:10.1636/0161-8202(2002)030[0047:CHICHS]2.0.CO;2

Roewer, C. F. (1928). Araneae, Echte oder Webespinnen. Die Tierwelt Mitteleuropas (Leipzig) 3, 1-144.

Romano, R., and Ferrández, M. A. (1983). Dysdera scabricula Simon 1882, nueva especie para la Península Ibérica con notas acerca de los dysderidos de la provincia de Navarra. In 'Actas I Congreso Ibérico de Entomología, León, 2’. pp. 685-697. (Asociación Española de Entomología: León, Spain.)

Rundle, H. D., and Nosil, P. (2005). Ecological speciation. Ecology Letters 8, 336-352. doi:10.1111/j.1461-0248.2004.00715.x

Schluter, D. (2001). Ecology and the origin of species. Trends in Ecology \& Evolution 16, 372-380. doi:10.1016/S0169-5347(01)02198-X

Schult, J. (1983a). Taster haplogyner Spinnen unter phylogenetischem Aspekt (Arachnida: Araneae). Verhandlungen des Naturwissenschaftlichen Vereins in Hamburg 26, 69-84.

Schult, J. (1983b). Dysdera - Portrait einer asseljagenden Spinne. Neue Entomologische Nachrichten 7, 17-20.

Simon, E. (1882). Etudes arachnologiques. 13e mémoire. XX. Descriptions d'espèces et de genres nouveaux de la famille des Dysderidae. Annales de la Société Entomologique de France 6, 201-240.

Simon, E. (1914). Les arachnides de France. In 'Synopsis Générale et Catalogue des Espèces Françaises de l'Ordre des Araneae; Tome VI, 1re Partie'. pp. 1-308. (Roret: Paris.)

Stamatakis, A. (2006). RAxML-VI-HPC: maximum likelihood-based phylogenetic analyses with thousands of taxa and mixed models. Bioinformatics 22, 2688-2690. doi:10.1093/bioinformatics/btl446

Staudt, A. (2015). Dysdera erythrina. In 'Nachweiskarten der Spinnentiere Deutschlands (Arachnida: Araneae, Opiliones, Pseudoscorpiones)'. Available at http://spiderling.de/arages/Verbreitungskarten/species. php?name=dysery [accessed 20 November 2016].

Stockman, A., and Bond, J. E. (2007). Delimiting cohesion species: extreme population structuring and the role of ecological interchangeability. Molecular Ecology 16, 3374-3392. doi:10.1111/j.1365-294X.2007. 03389.x

Sunderland, K. D., and Sutton, S. L. (1980). A serological study of arthropod predation on woodlice in a dune grassland ecosystem. Journal of Animal Ecology 49, 987-1004. doi:10.2307/4240

\section{5}


Sutton, S. L. (1980). 'Woodlice.' (Pergamon Press: New York, NY.)

Suzuki, S. (1954). Cytological studies in spiders III. Studies on the chromosomes of fifty-seven species of spiders belonging to seventeen families with general considerations on chromosomal evolution. Journal of Science of the Hiroshima University Series B 1, 23-136.

Taberlet, P., Fumagalli, L., Wust-Saucy, A. G., and Cosson, J. F. (1998). Comparative phylogeography and postglacial colonization routes in Europe. Molecular Ecology 7, 453-464. doi:10.1046/j.1365-294x. 1998.00289.x

10 Tang, C. Q., Humphreys, A. M., Fontaneto, D., and Barraclough, T. G. (2014). Effects of phylogenetic reconstruction method on the robustness of species delimitation using single-locus data. Methods in Ecology and Evolution 5, 1086-1094. doi:10.1111/2041-210X.12246

Thaler, K., and Knoflach, B. (2002). Zur Faunistik der Spinnen (Araneae) von Österreich: Atypidae, Haplogynae, Eresidae, Zodariidae, Mimetidae. Linzer Biologische Beiträge 34, 413-444.

Thorell, T. (1873). 'Remarks on Synonyms of European Spiders. Part IV.' (Uppsala, Sweden.), see pp. 375-645.

Uhl, G. (2000). Two distinctly different sperm storage organs in female Dysdera erythrina (Araneae: Dysderidae). Arthropod Structure \& Development 29, 163-169. doi:10.1016/S1467-8039(00)00019-0
Walckenaer, C. A. (1802). Faune parisienne. Insectes. In 'Histoire Abrégée des Insectes de Environs de Paris. Vol. 2'. pp. 187-250. (Paris.)

Wiehle, H. (1953). Spinnentiere oder Arachnoidea (Araneae) IX: Orthognatha, Cribellatae, Haplogynae, Entelegynae (Pholcidae, Zodariidae, Oxyopidae, Mimetidae, Nesticidae). In 'Die Tierwelt Deutschlands und der Angrenzenden Meeresteile nach ihren Merkmalen und nach ihrer Lebensweise. 42. Teil'. (Ed. F. Dahl.) pp. 1-150. (Gustav Fischer Verlag: Jena, Germany.)

World Spider Catalog (2016). World Spider Catalog, version 17: 0. Natural History Museum Bern. Available at http://research.amnh.org/iz/spiders/ catalog [accessed 18 May 2016].

Zhang, J., Kapli, P., Pavlidis, P., and Stamatakis, A. (2013). A general species delimitation method with applications to phylogenetic placements. Bioinformatics 29, 2869-2876. doi:10.1093/bioinformatics/btt499

$$
\text { Handling editor: Mark Harvey }
$$




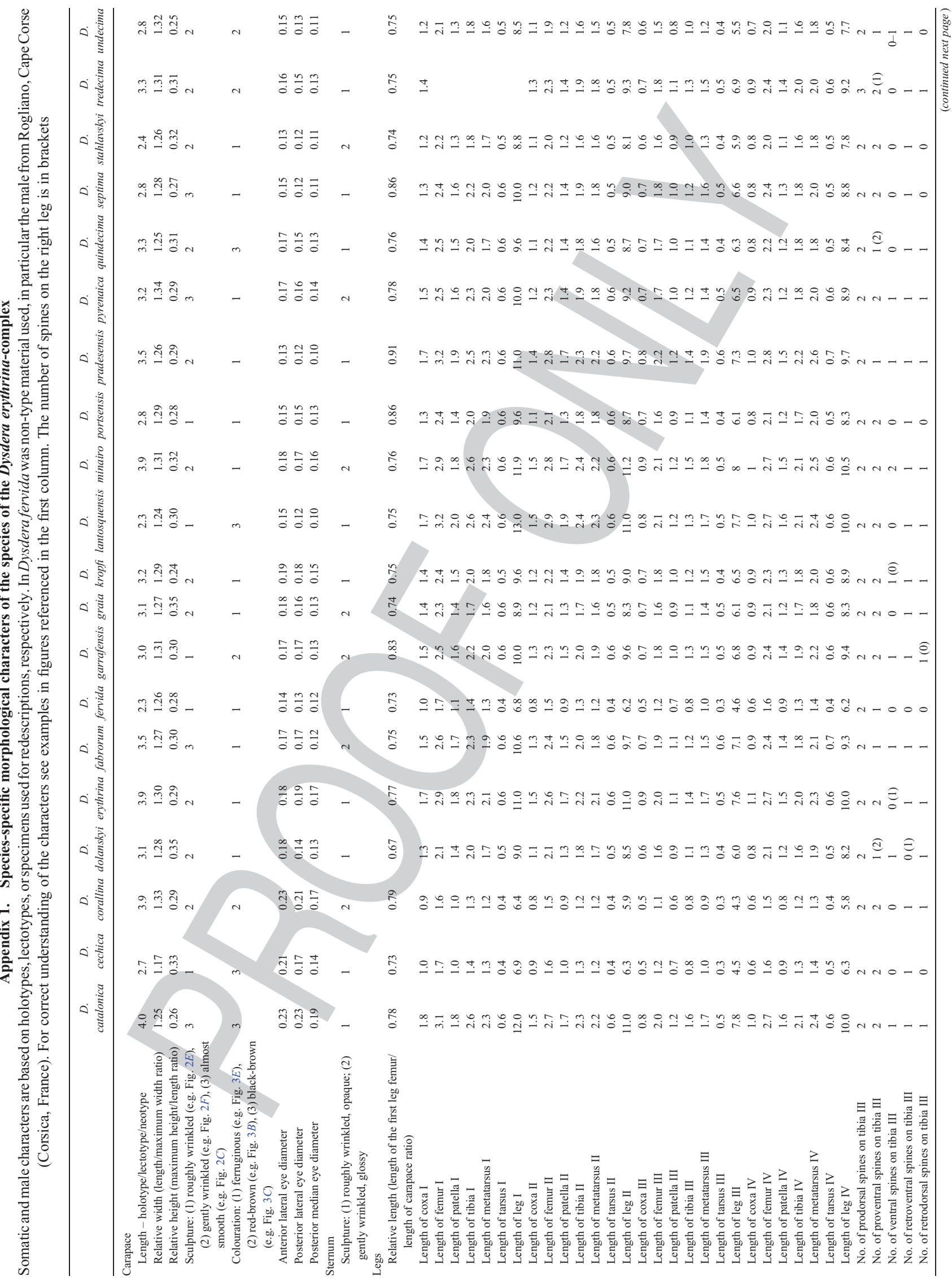




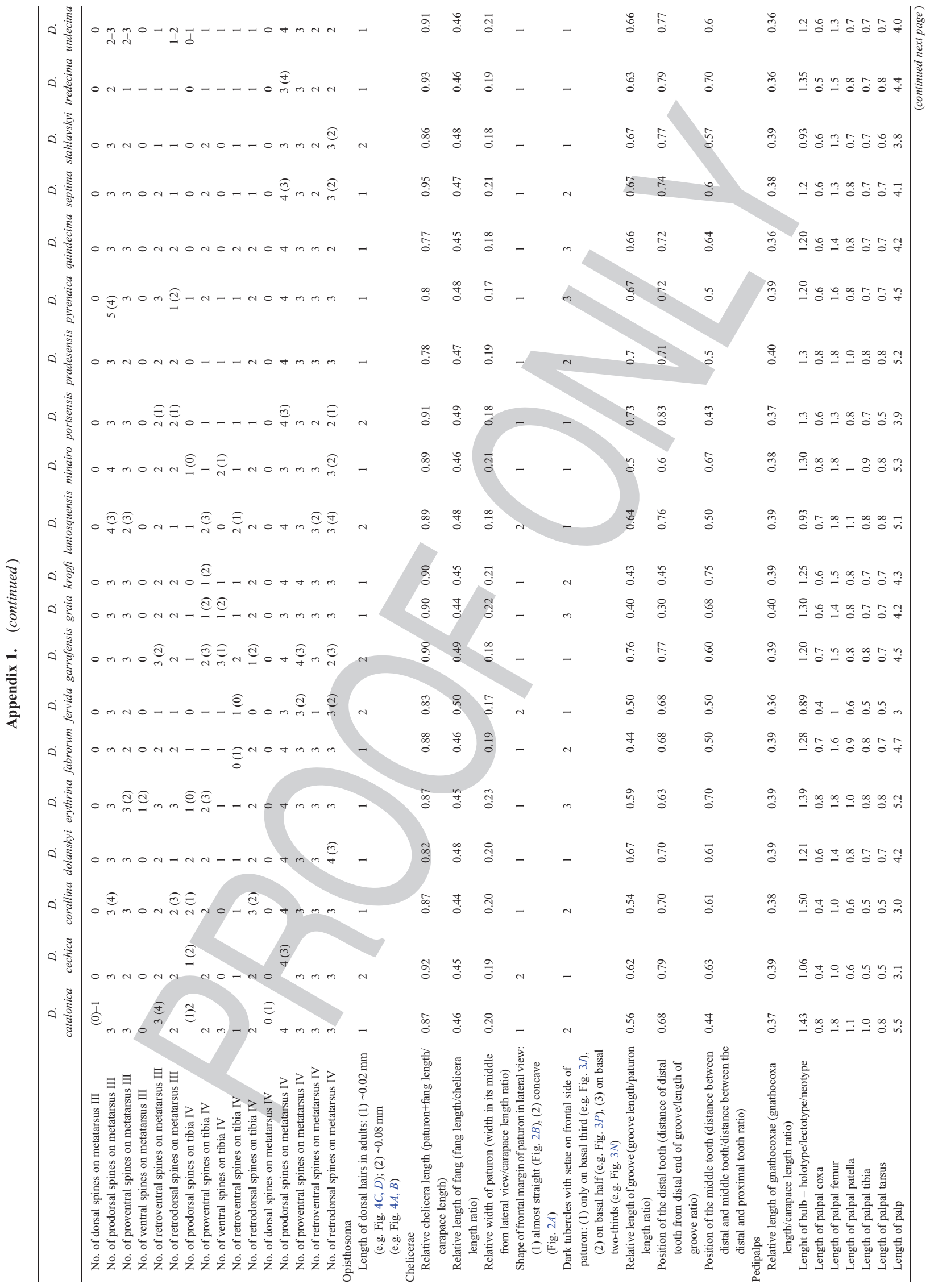


AR Invertebrate Systematics

M. Řezáč et al.

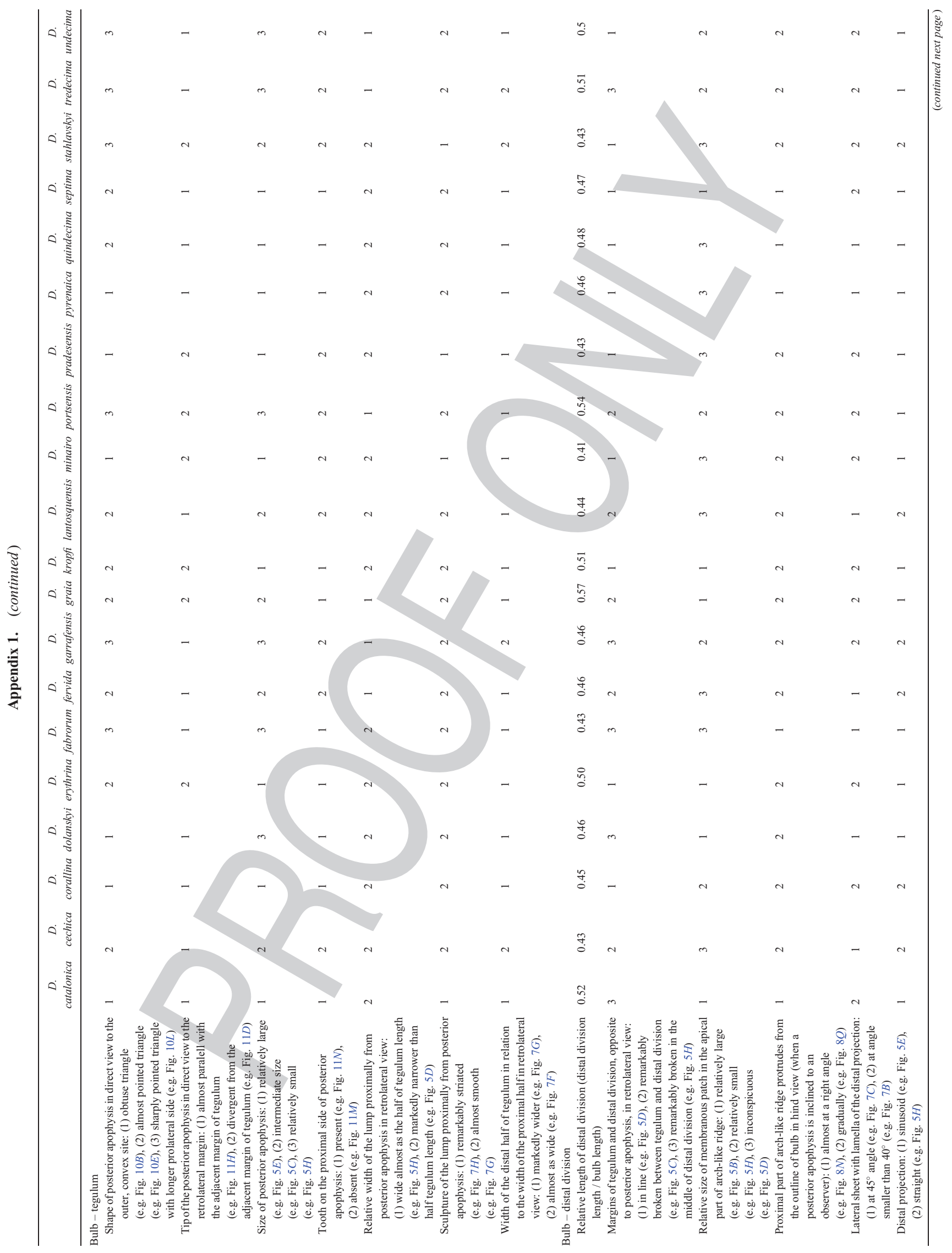


Revision and speciation mode of spider complex Dysdera erythrina

Invertebrate Systematics

AS

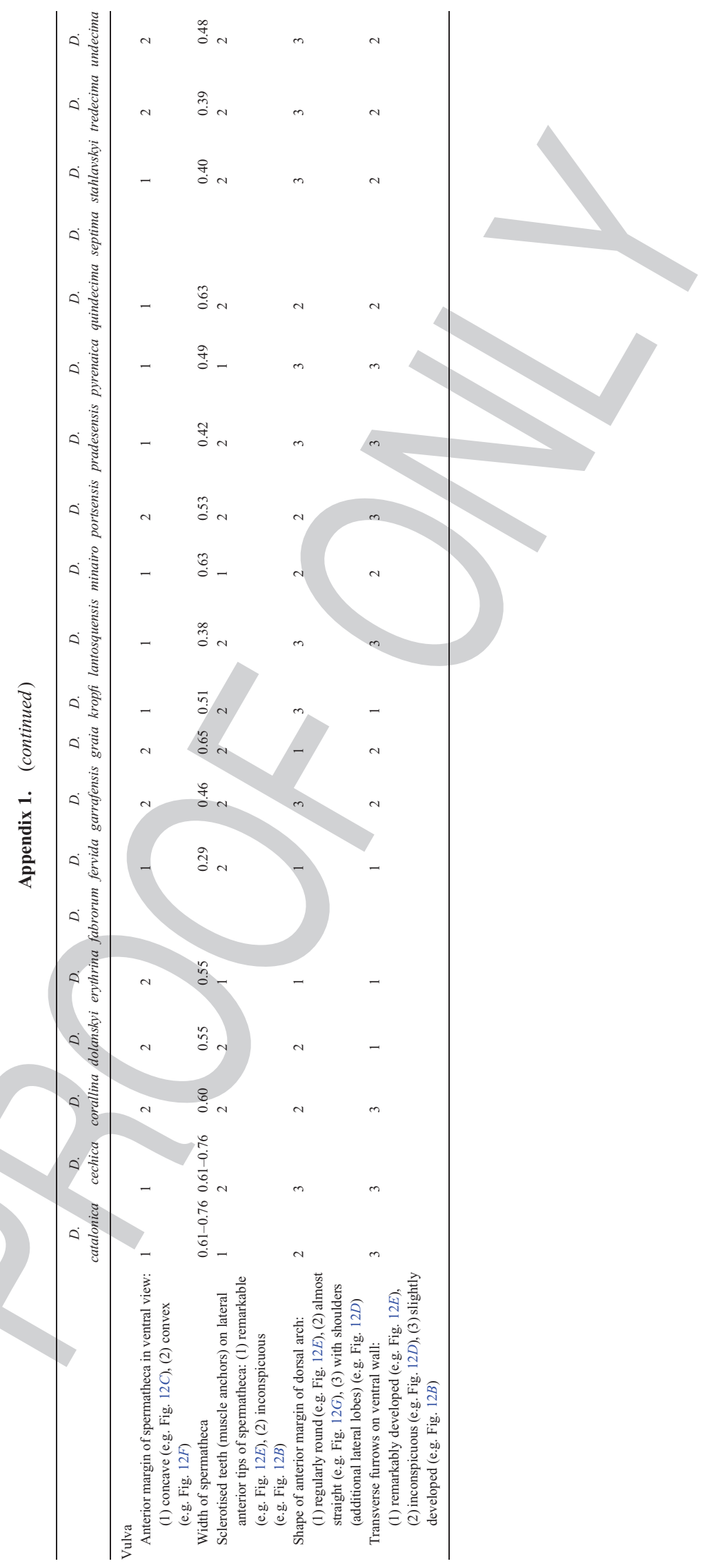

www.publish.csiro.au/journals/is 


\section{AUTHOR QUERIES}

1. Au: The text was revised from ratio length/maximum width to length/maximum width ratio. Is that correct?

Here and elsewhere the same edits were made. Please advise if this is ok.

2. Au: Is there a number associated to the figure on $\mathrm{p}$. 95 ? (i.e. please provide missing information - fig. X on p. 95 .

3. Au: Please advise. Are you citing a book in Chyser and Kulczyński (1987). If so, the reference needs to be formatted to the following

Author names (publication year). 'Title of the book.' (name of Publisher: Location of publisher).

If you are citing a book chapter, then the following format applies:

Author names (publication year). Title of the book chapter. In 'Title of the main book'. Page range of the book chapter. (name of Publisher: Location of publisher.)

4. Au: Please advise. Are you citing a book in Hahn (1831). If so, the reference needs to be formatted to the following

Author names (publication year). 'Title of the book. ' (name of Publisher: Location of publisher).

5. Au: Please advise. Are you citing a book in Koch (1838). If so, the reference needs to be formatted to the following

Author names (publication year). 'Title of the book.' (name of Publisher: Location of publisher). 